Portland State University

PDXScholar

4-1981

\title{
The Biogeography of Oregon White Oak (Quercus garryana) in Central Oregon
}

Robert Allen Voeks

Portland State University

Follow this and additional works at: https://pdxscholar.library.pdx.edu/open_access_etds

Part of the Spatial Science Commons

Let us know how access to this document benefits you.

\section{Recommended Citation}

Voeks, Robert Allen, "The Biogeography of Oregon White Oak (Quercus garryana) in Central Oregon" (1981). Dissertations and Theses. Paper 3545.

https://doi.org/10.15760/etd.5429

This Thesis is brought to you for free and open access. It has been accepted for inclusion in Dissertations and Theses by an authorized administrator of PDXScholar. Please contact us if we can make this document more accessible: pdxscholar@pdx.edu. 
AN ABSTRACT OF THE THESIS OF Robert Allen Voeks for the Master of Science in Geography presented April, 1981.

Title: The Biogeography of Oregon White Oak (Quercus garryana) in Central Oregon.

APPROVED BY MEMBERS OF THE THESIS COMMITTEE:
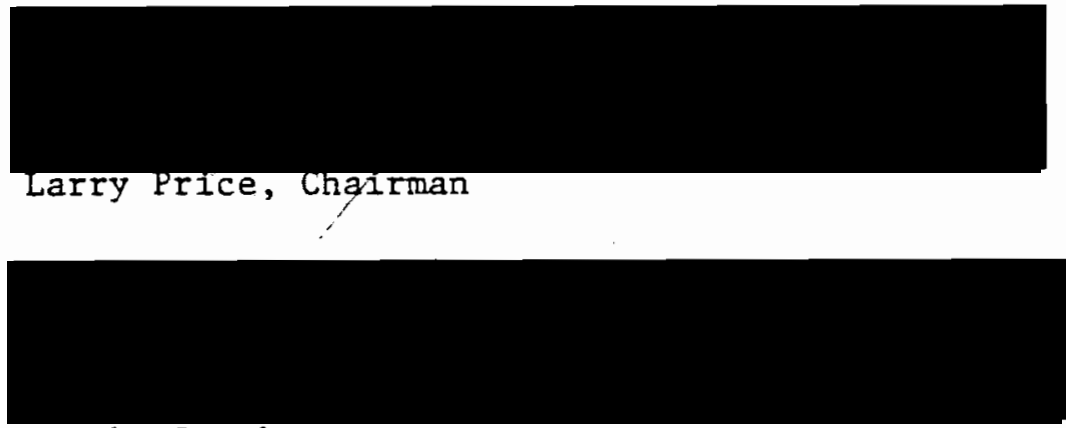

Clarke Brooke

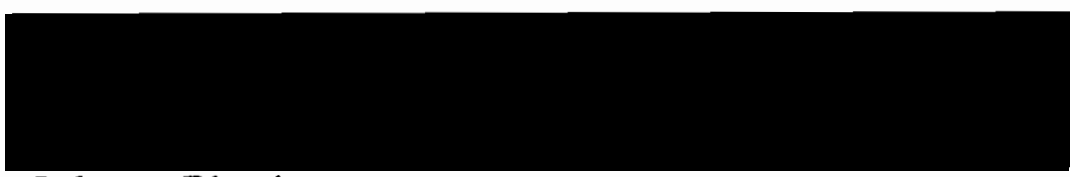

Robert Tinnin 


\section{ABSTRACT}

Oregon white oak (Quercus garryana) is distributed along a north-south swath from British Columbia to central California, bounded on the west by the Coast Range and on the east by the Sierra/Cascade cordillera. It departs from this linear path near latitude $46^{\circ} \mathrm{N}$, where it passes east through the Columbia River Gorge Into central Oregon and Washington. Here it occupies a distinct eastern Cascade foothill zone between Douglas fir/ponderosa pine associations and juniper/sagebrush/grassland habltats. This thesis examines $Q$. garryana's range extension into this portion of north-central Oregon.

The study proceeded as follows: The distribution of $Q$. garryana was mapped through field reconnaissance. Annual rings from fifteen trees were counted in order to establish age versus trunk diameter ratios. This greatly simplified the dating of trees. Transects were then run through individual groves to determine population age structures. These age structures, along with $\underline{Q}$. garryana's distribution patterns, were graphically compared with historic temperature, precipitation, and growing season data. The effect of livestock grazing on oak reproduction was examined. Potential vagility of the species was evaluated by estimating the potential for acorn dispersion by airfall, streams, vertebrates, and the human (aboriginal) population. Finally, pollen evidence was scrutinized in conjunction with acorn dispersal rates in order to determine the longer term history of $Q$. garryana in this portion of its range. 
The age structure results indicate that $Q$. garryana is maintaining a stable population equilibrium: While it is neither expanding nor contracting its range, it is reproducing at an adequate pace to maintain its present range and numbers. Further, the data suggest that oak is a climax species in central oregon, occupying an exclusive environment between the more mesic coniferous associations and the more xeric grassland/juniper/sagebrush communities.

Q. garryana's reproductive equilibrium at individual sites is largely a function of historic precipitation fluctuations. Thus, the 1930s drought favored increased oak reproduction at its moist (coniferous) frontier but decreased reproduction near its xeric border. Particularly moist spells contributed to a reversal of this trend. Q. garryana thus appears to be in constant flux between upslope or downslope migration in response to moisture availability.

Sites which are heavily grazed by livestock lack reproductive equilibrium; in some cases oak has not propagated in fifty years. Nevertheless, oak seedlings appear to be capable of quickly repopulating heavily grazed areas when the cattle are removed. Similar soil disturbances such as periodic ground fires, on the other hand, may play a beneficial role in oak seedling success through elimination of the thick organic mat.

In increasing order of importance, Douglas' squirrels (Tamiasciurus douglassi), Lewis' woodpeckers (Asyndesmus lewis), and Steller's jays (Cyancitta stelleri) were found to be effective agents of acorn dispersal. Stellers jays, which usually carry 
acorns upslope into nearby coniferous areas, contribute to the highest potential oak migration rate of $20 \mathrm{~km}$ per 1000 years. Lewis' woodpeckers, which often cache acorns in drier downslope areas, provide a potential population extension of $4 \mathrm{~km}$ per 1000 years. Indians were largely discounted as dispersers of viable acorns due to their practice of roasting acorns prior to transport. The action of $\underline{Q}$. garryana acorns falling and rolling away from the seed tree is not an effective means of acorn dispersal. And due to their heavy weight, acorns are probably not transported by streams, although turbulent flood conditions might allow this to occur.

By applying the maximum calculated oak migration rate to the chronology of oak's presence (as established by pollen evidence) in the Pacific Northwest, it is shown that rather than migrating to its present position in post-Pleistocene times, Q. garryana must have survived Ice Age conditions at sporadic locations throughout the Willamette-Puget Trough.

Finally, Q. garryana's anomalous presence east of the Cascades is accounted for by either post-Missoula Flood migration from the Willamette Valley through the Columbia River Gorge or by its uninterrupted presence in central Oregon from previous interglacials or even earlier. 
THE BIOGEOGRAPHY OF OREGON WHITE OAK (Quercus

garryana) IN CENTRAL OREGON

by

ROBERT ALLEN VOEKS

A thesis submitted in partial fulfillment of the requirements for the degree of

MASTER OF SCIENCE

IN

GEOGRAPHY

Portland State University

1981 
TO THE OFFICE OF GRADUATE STUDIES AND RESEARCH:

The members of the Committee approve the thesis of Robert Allen Voeks presented Apri1, 1981.

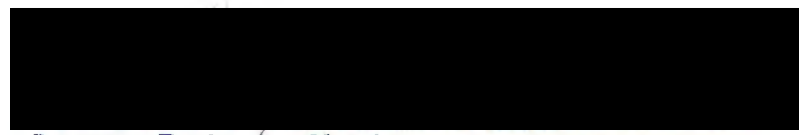

Larry Price, Chairman

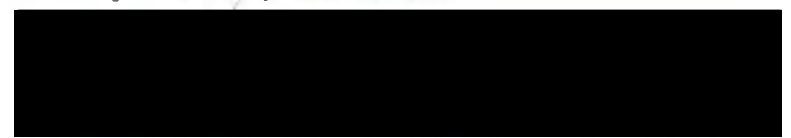

Clarke Brooke

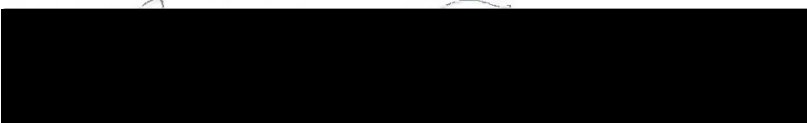

Robert Tinnin

Richard Lycan, Head, Department of Geography

Stanłey E. Rauch, Dean, Graduate Studies and Research 


\section{ACKNOWLEDGEMENTS}

The following thesis would not have been initiated and might not have been completed without the gentle prodding of Dr. Larry Price, and the field work might have been a burden without the good-natured assistance of Jo Tucker and Zonnie Bauer.

I would also like to thank the following people for helpful advice and ideas: Dr. Robert Tinnin, Dr. David French, Dr. Dan Johnson, Michael Deathridge-Newsom and Gary Medders. 
TABLE OF CONTENTS

PAGE

ACKNOWLEGMENTS . . . . . . . . . . . . . . . . . .

LIST OF TABLES . . . . . . . . . . . . . . . . . . vii

LIST OF FIGURES . . . . . . . . . . . . . . . . . . . viii CHAPTER

I INTRODUCTION . . . . . . . . . . . . . . . 1

II LITERATURE REVIEW . . . . . . . . . . . . . 4

Previous Distribution of Oregon White Oak . . . 4

Present Distribution of Oregon White Oak . . . 7

Ecological Relationships . . . . . . . . 9

III SITE DESCRIPTION . . . . . . . . . . . . 15

Geology .................. 15

Climate . . . . . . . . . . . . 15

Vegetation ............... 17

Land Use . . . . . . . . . . . . 17

IV METHODOLOGY . . . . . . . . . . . . 20

V OREGON WHITE OAK'S POPULATION STATUS . . . . . . . 23

Introduction . . . . . . . . . . . . 23

Oak Size-Structure Data . . . . . . . . 24

Discussion . . . . . . . . . . . . 24

VI THE EFFECTS OF CLIMATE ON OREGON WHITE OAK . . . . . . 42

Introduction .............. . . 4 42

General Climatic Considerations . . . . . . 42

Temperature and Precipitation Fluctuations . . . 43

Comparison of Oak Size-Structures to Climatic Change 56 
Table of Contents (Continued)

CHAPTER

PAGE

Sites with a Positive Size-Structure Versus

Climatic Correlation ........... .

Sites with a Negative Size-Structure Versus Climatic Correlation .. . . . . . . . .

Combined Size-Structure Versus Climatic Correlation . . . . . . . . . . . . .

Slope Aspect Versus Climatic Correlation . . . 67

Summary .............. . . 69

VII EFFECTS OF GRAZING ON OREGON WHITE OAK . . . . . 70

Introduction ............. . . 70

Grazing Observations ........... . 71

Summary . . . . . . . . . . . . 76

VIII VAGILITY OF OREGON WHITE OAK ACORNS . . . . . • . 78

Introduction .............. . . 78

Gravity Fall and Hillside Rolling of Acorns . • 79

Running Water Transport ......... 82

Animal Transport of Acorns ......... 84

Man's Role in Acorn Dispersal ........ 88

Summary ............... 90

IX MIGRATIONAL HISTORY OF OREGON WHITE OAK . • • 92

Introduction ............ . . 92

History of the Vegetation in the Pacific Northwest 92

Pollen Interpretation . . . . . . . . 93

Hypsithermal Relicts............. 96

Chronology of Migration in Oregon White Oak . . 99

Summary . . . . . . . . . . . . 101 
Table of Contents (Continued)

CHAPTER

$\mathrm{X}$ MAJOR CONCLUSTONS

Methodological Conclusions

Biogeographic Conclusions . . . . . . . 103

REFERENCES . . . . . . . . . . . . . . . . . . 106

APPENDIX I . . . . . . . . . . . . . . . . . . . . . 112

APPENDIX II . . . . . . . . . . . . . . . . . . 113

APPENDIX III . . . . . . . . . . . . . . . 116 
TABLE

PAGE

I Features of Study Sites . . . . . . . . . . 25

II Size-Class Data by Site . . . . . . . . . . 27

III Totals of Size-Class Data . . . . . . . . . 37

IV Mean Temperature and Precipitition Data: Hood River - 48

V Mean Temperature and Precipitation Data: The Dalles . 49

VI Mean Temperature and Precipitation Data: Dufur . . . 50

VII Mean Temperature and Precipitation Data: Madras . . 51

VIII Oregon White Oak Tree Ring Data . . . . . . . 57

IX Animals Observed Carrying or Eating Acorns . . . . . 71

X Observed Effects of Grazing . . . . . . . . . 74

XI Comparison of Climatic Data to Size-Structures . . . 74

XII Distance and Direction of Marked Acorns from Seed Tree 80

XIII Chronology of Pollen Stratigraphy . . . . . . . . 95 


\section{LIST OF FIGURES}

FIGURE

PAGE

1. The Distribution of Oregon White Oak . . . . . . .

2. The Distribution of Oregon White Oak in North-Central

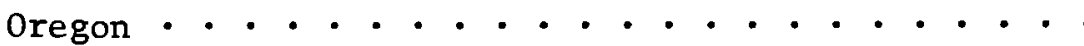

3. A Pure Stand of Oregon White Oak . . . . . . . . 18

4. Oak's Population Size-Structure at Site 1 . . . . . 28

5. Douglas Fir's Population Size-Structure at Site $\#_{1}$. . 28

6. Ponderosa Pine's Population Size-Structure at Site 1 1 28

7. Oak's Population Size-Structure at Site $\# 2$. . . . . 29

8. Douglas Fir's Population Size-Structure at Site 非 . . 29

9. Oak's Population Size-Structure at Site 非 . . . . . 29

10. Douglas Fir's Population Size-Structure at Site $\#_{3}$. . 30

11. Ponderosa Pine's Population Size-Structure at Site $\$ 3 \quad 30$

12. Oak's Population Size-Structure at Site $\$$. . . . . . 30

13. Oak's Population Size-Structure at Site \#5 . . . . . 31

14. Oak's Population Size-Structure at Site \#6 . . . . . 31

15. Ponderosa Pine's Size-Structure at Site \#6 . . . . . 32

16. Oak's Population Size-Structure at Site \#7 . . . . 32

17. Ponderosa Pine's Population Size-Structure at Site \# $8 \quad 32$

18. Oak's Population Size-Structure at Site \#8...... 33

19. Oak's Population Size-Structure at Site $\$ 9$. . . . . 33

20. Oak's Population Size-Structure at Site 110 . . . . 33

21. Oak's Population Size-Structure at Site $\# 11$. . . . 34

22. Oak's Population Size-Structure at Site $\# 12$. . . . 34

23. Oak's Population Size-Structure at Site $\# 13$. . . . . 34

24. Oak's Population Size-Structure at Site \#14 . . . . 35 
List of Figures (Continued)

FIGURE

PAGE

25. Oak's Population Size-Structure at Site \#15 . . . . . 35

26. Oak's Totaled Size-Structure Data for North Facing Slopes ................. . . 38

27. Oak's Totaled Size-Structure Data for South Slopes. . . 39

28. Oak's Totaled Size-Structure Data for All Sites.... 40

29. Mean Monthly Precipitation: Hood River, Oregon . . . 44

30. Mean Monthly Precipitation: The Dalles, Oregon .... 44

31. Mean Monthly Precipitation: Dufur, Oregon ...... 45

32. Mean Monthly Precipitation: Madras, Oregon ...... 45

33. Comparison of Mean Annual Precipitation to Oak's Distribution.................... 46

34. Comparison of Frost-Free Days per Year with Oak's Distribution ....................

35. Mean Annual Precipitation Fluctuations in Central Oregon 53

36. Mean Annual Temperature Fluctuations in Central Oregon 53

37. Spring (Apr.-May) Mean Precipitation Fluctuations in Central Oregon ................ 54

38. Autumn (Oct.-Nov.) Mean Precipitation Fluctuations in Central Oregon . . . . . . . . . . . . 54

39. Spring (Apr.-May) Mean Temperature Fluctuations in Central Oregon . . . . . . . . . . . . . . .

40. Autumn (Oct.-Nov.) Mean Temperature Fluctuations in Central Oregon . . . . . . . . . . . 55

41. Age-DBH Correlation for Oregon White Oak . . . . . 58

42. Oak Coppice Sprouting in Butler Canyon ......... 61

43. Dense, Scrubby Oak Stand Near Mosier Creek ...... 63

44. Dead Douglas Fir Amid Living Oak During the 1977 Drought 68

45. Fallen Acorn Locations Under the Seed Tree . . . . 81 
List of Figures (Continued)

FIGURE

PAGE

46. Lewis'Woodpecker Carrying an Acorn . . . . . . . .

47. Acorns Cached in a Telephone Pole by a Lewis' Woodpecker 


\section{CHAPTER I}

\section{INTRODUCTION}

Oregon white oak (Quercus garryana) occurs in the Pacific Northwest between the Cascade Mountains and the Coast Range, extending from latitude $49^{\circ} 30^{\prime} \mathrm{N}$ in British Columbia south into central California at latitude $36^{\circ} \mathrm{N}$. Its north-south distribution is interrupted by a small range extension eastward along the Columbia River Gorge into the semi-arid steppe region of central Oregon and Washington. The following thesis is an examination of Oregon white oak's location and status in central Oregon.

Plant geography involves the description and interpretation of plant distributions. Plants or their associations are depicted on maps and evaluated through various methods in order to establish their relation to the physical and biotic environment. An array of methods may be employed, including: climatic evaluation, field ecological and taxonomic study, pollen and fossil research, historical reference, cultural tradition and legend, and other methods. Through integration of these data, meaningful deductions about floral distribution and dynamics can be made.

Oregon white oak is the only member of the genus Quercus occurring north of southern Oregon in the western United States. It grows primarily in the deep alluvial soils, level to gently hilly terrain, and in a west coast marine climate characterized by cool, moist winters and warm, dry summers. Oak woodlands form the ecotone between the Douglas fir and grassland associations. The native grasslands, however, have been extirpated by agricultural expansion. Oregon white oak is like- 
wise being replaced through human intervention, as well as by overtopping by Douglas fir, which has been invading oak woodlands since the 1850 s.

The extension of oak through the Columbia River Gorge into central Oregon and Washington is a deviation from the normal conditions just depicted. The vegetation and soils change radically in a short distance from west to east in response to the transition from a west coast marine to a continental climatic regime characterized by increasing aridity and seasonal temperature extremes. The vegetation grades from coniferous forest to oak woodland to sagebrush-juniper-grasslands. The soils likewise change from deep alluvial to thin, desert soils.

It can be seen that the extension of Oregon white oak's range into central Oregon presents a unique biogeographic situation whereby a plant's distribution can be studied with respect to radically changing geographic factors in a small area. Processes and stages observed within this limited area may then be cautiously applied to $\underline{Q}$. garryana's entire distribution.

Several methods of enquiry have been used in this study. Oak populations were field mapped on foot and by car on a 1:125000 topographic map. Age-structures were constructed for several oak stands and compared to population equilibrium curves. Variations from the curves, which indicate a fluctuating rate of regeneration, were dated and compared to the area's temperature and precipitation data for possible cause and effect relationships. Sites whose age-structures failed to correlate with climatic data were considered in light of livestock grazing pressure.

Probable modes of acorn dispersal resulting in oak population diffusion were also considered. Acorn transport away from the parent tree 
by means of gravity, streams and wildlife were measured or estimated. The records of early explorers and settlers were consulted in order to determine the role of native Indians in the transport of acorns. The potential rates of oak population migration as calculated from these results were considered in respect to post-Pleistocene climatic change and oak's chronological position in the pollen record. From these data, the routes and timing of Oregon white oak's migration into the Willamette-Puget Trough and central Oregon are proposed. 


\section{CHAPTER II}

\section{LITERATURE REVIEW}

\section{PREVIOUS DISTRIBUTION OF OREGON WHITE OAK}

The genus Quercus is represented in western North America by fossil and pollen evidence. It first appeared in Eocene (36-53 million years before present) floral assemblages characterized by subtropical families such as Palmae and Moraceae. As the climate cooled during the Oligocene (25-36 m.y.b.p.), subtropical taxa such as Metasequoia, Juglans, Betula, and the ancient relatives of Quercus migrated southward into what is now Montana (Axelrod, 1976; Chaney, 1948; Detling, 1968; Wolfe, 1969). During these epochs, the Pacific Northwest was dominated by shallow inland seas. With the dawn of the Miocene (7-25 m.y.b.p.), terrestrial environments supplanted the seas and the climate cooled and dried. Species diversity increased and later decreased during this epoch; Quercus was represented by at least 10 species (Wolfe, 1969). Notable among these taxa was Quercus pseudolyrata, a close relative of $\underline{Q}$. kelloggii, which now occurs in southern Oregon.

During the Pliocene $(2-7 \mathrm{~m} \cdot \mathrm{y} \cdot \mathrm{b} \cdot \mathrm{p}$.$) , tectonic processes recontoured$ the western landscape. The leeside climates of Oregon, Washington, California, and Nevada were slowly desiccated by the emergence of the Cascade Mountains and the Sierra Nevada. The climate of Pliocene western America began to resemble present conditions (Wolfe, 1969).

The Deschutes River Pliocene flora, as reconstructed from locations near the present study site, reveal similar vegetation types to those found there today. Close relatives of Populus tricocarpa, P. 
tremuloides, and Acer negundo are well represented by fossils. Quercus fossils are not present in this formation but are recorded in the nearby Dalles formation. These fossils, however, are considered unlikely ancestors of Quercus garryana (Chaney, 1944).

The vegetation changes during the Quaternary Period (2 m.y.b.p. to present) have been considered in light of local pollen deposits. Unfortunately, this evidence is confined to the present interglacial period, reaching back little further than 15,000 years. Pollen profiles evaluated by Hansen (1938, 1940; 1941a, b; 1942; 1943a, b, c; 1947) and Heusser $(1969 ; 1964)$ for the Willamette-Puget Trough reveal the following post-glacial succession: 1) early invasion by lodgepole pine (Pinus contorta) along with large numbers of Sitka spruce (Picea sitchensis) and fir (Abies ssp); 2) gradual replacement by Douglas fir (Pseudotsuga menziesii); encroachment by more xeric species including Oregon white oak and various grasses. (Heusser, 1960); and re-emergent dominance by Douglas fir. This species is presently the numerical dominant, while ceding on cooler and moister sites to western hemlock (Tsuga heterophyla) and in drier areas to Oregon white oak.

The vegetational history east of the Cascades is more problematic, as conditions are less than optimal for pollen profile development. Pollen evidence from eastern Washington reveals oscillations between the sagebrush (Artemisia, ssp), western juniper (Juniperus occidentalis) and ponderosa pine (Pinus ponderosa) associations. Early in the postglacial, lodgepole pine dominated much of the area. As the climate warmed, ponderosa pine largely replaced lodgepole pine. At the maximum of xerix conditions during the Hypsitherm (Deevey, 1957) grasses and chenopods (Chenopodiaceae) increased relative to ponderosa pine. Post- 
Hypsithermal climatic cooling has led to an increase in ponderosa pine east of the Cascades (Hansen, 1947).

The Hypsitherm figures prominantly in the vegetational history of the Pacific Northwest, particularly in regards to Q. garryana. Detling (1961) set limits on the temperature and precipitation changes necessary to account for the multiplication of xeric species during this period, Including: a decrease of $230 \mathrm{~mm}$ of precipitation per year; a rise in the winter mean temperature of $1.0^{\circ} \mathrm{C}$; and an increase in summer mean temperatures of at least $5.0^{\circ} \mathrm{C}$.

Oregon white oak is thought to have penetrated central Oregon during the Hypsitherm. Detling (1958, 1961, 1966, 1968) discussed the relict status of both boreal and chaparral species at various oregon locations. He located several pockets of endemic boreal flora at low elevations which he attributed to down-slope migration during a glacial advance and later retreat upslope during a warmer inter-glacial, thus stranding disjunct islands of flora. He further identified several floral associates of the California-Oregon chaparral formation (including Oregon white oak) at scattered sites throughout the Northwest; he considered these to be xeric island relicts of the Hypsithermal vegetation advance. Thus, the northern California chaparral formation migrated into the Klamath Basin during the climatic maximum, followed the Willamette-Puget Trough north and

...under less xeric conditions, the Garry Oak Woodland invaded the area [Columbia River Gorge] east from the west. (Detling, 1961, p. 356)

Detling bases this assumption on his conclusion that oak could not have tolerated Pleistocene conditions north of the Klamath highlands and thus must have migrated to its present position after the last glacial ad- 
vance (Detling, 1968). Ross (1975), however, implies that oak may have weathered Ice Age conditions in favorable microhabitats.

Hickman (1968) also evaluated disjunct xeric species in the Willamette Valley and considered two alternatives to account for their distribution: they were either vanguards of an expanding population or relicts of a retreating floral assemblage. Considering the continuity of species composition between several disjunct sites, Hickman agreed with Detling's hypothesis of Hypsithermal relicts.

\section{PRESENT DISTRIBUTION OF OREGON WHITE OAK}

Oregon white oak is presently distributed in a north-south swath through the states of California, Oregon, Washington, and in British Columbia (Figure 1). It is found tucked between the Cascade Mountains and the Coast Range. In California, it occurs at isolated sites as far south as Tulare County and in the Santa Cruz Mountains north of Monterey Bay. Oregon white oak becomes a conspicuous member of the oak woodland community in northern California. In Oregon and Washington, it follows the Willamette-Puget Trough north to Vancouver Island, deviating from this linear distribution in three places: 1) on the Chetko River on the seaward side of the Siskiyou Mountains; 2) in British Columbia along the Fraser River; and 3) in Oregon and Washington on both sides of the Columbia River Gorge and into central Oregon and Washington (USDA, 1965). The eastern extension of oak stops at the confluence of the Deschutes River, just as it did in 1804, as noted by the explorers Lewis and Clark (Thwaites, 1904). 


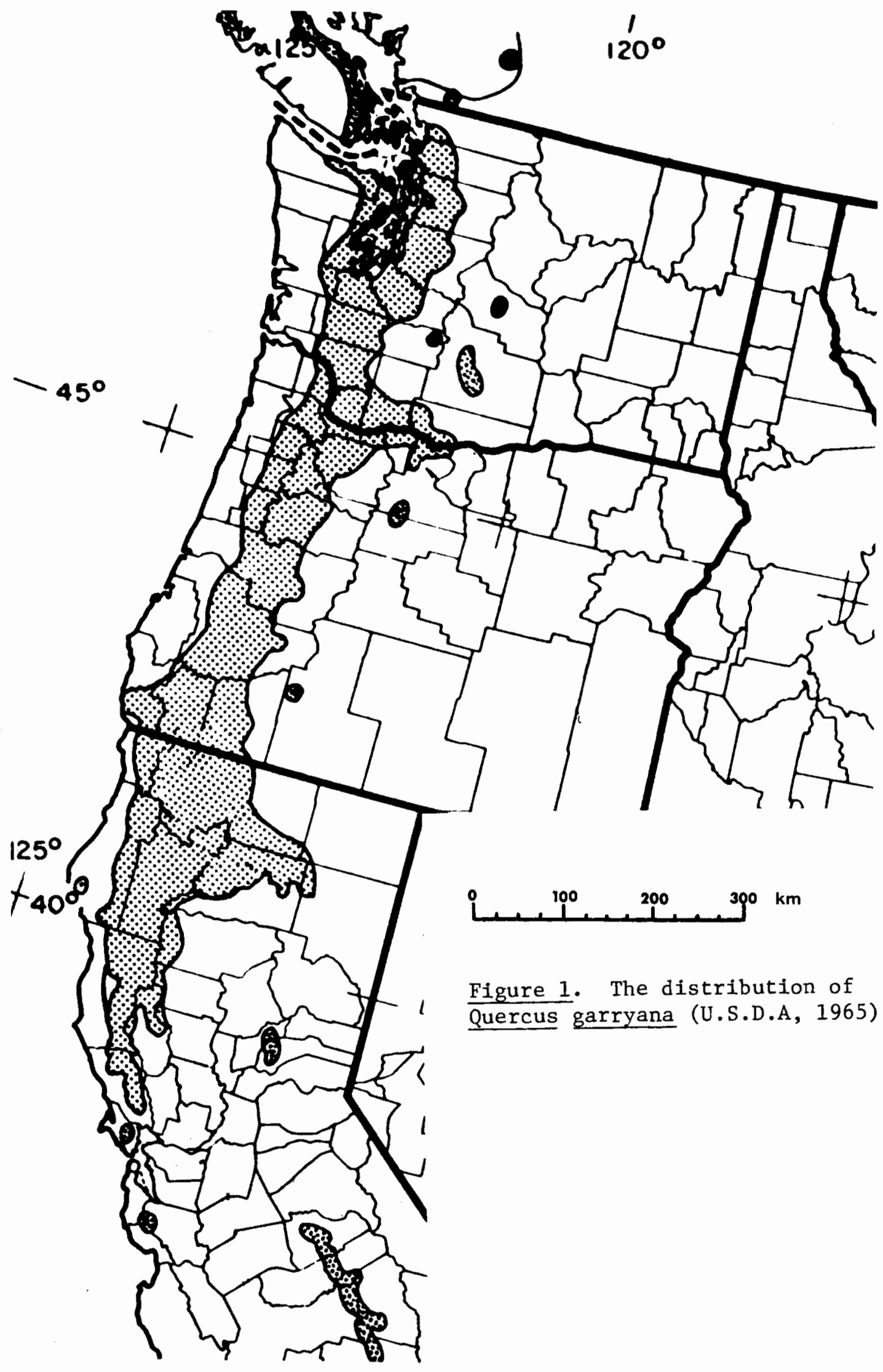




\section{ECOLOGICAL RELATIONSHIPS}

The ecology of the genus Quercus involves the interaction of plant growth and reproduction relative to a host of factors, including: climate, fire, soil, grazing, interspecific competition, wood production, and acorn utilization. Since little work has been done on $\underline{Q}$ garryana specifically, much of the following information is inferred from studies of closely related species.

Oak is ultimately dependent upon carbohydrate production and absorption of organic and inorganic nutrients. Water is the medium of transport both from soil to root and from root throughout the tree, as well as being necessary in the photosynthetic process. Critical temperatures must be maintained at the root and stem levels to ensure favorable metabolism. Oak maintenance is thus essentially a function of moisture, temperature and insolation (Kozlowski, 1962).

Little is known about Oregon white oak's climatic requirements aside from those interpreted from its current range. Comparison of its distribution to Koppen's climatic regions places oak largely in a marine west coast regime, with $\operatorname{cool}$ wet winters and warm summers with a distinct summer drought (Visher, 1954). Its range is delimited by a 600$1000 \mathrm{~mm}$ mean annual isohyet, although its distribution more closely correlates with a 100-200 mm April through September growing season isohyet. Low temperatures, snowfall, and early or late frosts are apparently not limiting to Q. garryana's growth or reproduction (USDA, 1965).

Oregon white oak may be a successionary species in the willamette Valley, able to historically fend off invasion by its rival Douglas fir only through its tolerance of fire. Prior to white settlement, the Valley vegetation graded from riparion forests to prairies punctuated 
by broad, savanna-form oaks to oak openings and Douglas fir forests in the foothills. As a result of grass fires - set by Indians to improve deer hunting - Douglas fir was excluded from much of the valley floor and immediate hinterlands. Oak, however, due to its fire tolerance and coppice sprouting ability, withstood these low intensity fires at scattered locations. With the cessation of burning after 1850, oak and Douglas fir quickly invaded oak openings and prairies not given over to cultivation. Douglas fir has subsequently overtopped oak in many of these areas (Habeck, 1961; Johannessen, et al., 1971; Sprague, 1946); thus oak's widespread presence in the Willamette Valley may be considered a cultural phenomena related to periodic burning.

Oak regeneration is most sensitive to atmospheric conditions during seed maturation and germination. Acorns mature in one season, germinating in September of October. The acorn contains carbohydrates and water for the initial radicle growth, although additional water is needed immediately after the radicle penetrates the soil (Korstian, 1927). Leaf litter or some other protection from dessication is imperative for the young acorn. Under experimental conditions, it was found that Quercus alba, an eastern white oak, had the following survival rates when planted at various depths: $37 \%$ survival at $10 \mathrm{~cm} ; 57 \%$ survival at $5 \mathrm{~cm}$; $73 \%$ survival at $1.5 \mathrm{~cm}$; and $5 \%$ survival on the bare soil (Korstian, 1927). Further, since $Q$. garryana germinates in the autumn and young radicles are susceptible to frost damage, early frost could be damaging, especially under the more continental climatic conditions of the study site.

The soils that support oak stands vary greatly. Although soil moisture is a necessity, under saturated conditions oxygen deficiency 
may be a limiting factor (Kramer, 1960). Oregon white oak grows on several soil types, from stoney and gravelly to dense clayey soils (USDA, 1965). In the Willamette Valley, Thilenius (1968) found oak populations ranging from well-drained acidic illuviated soils to poorly drained clayey soils in the valley bottoms.

Plant consumption and the accompanying soil disturbance by large domestic herbivores is an important factor in tree reproduction. Weaver (1950) felt that grazing by domestic livestock indirectly increased ponderosa pine seedling survival through soil disturbance. Oregon white oak may also benefit from ungulate grazing:

As most of these sites are being grazed, competition from other species is lessened and the acorns from the Quercus trees are able to germinate and seedlings can grow...there are generally enough young Quercus trees on these sites for replacement. (Thilenius, 1964, p. 115)

In Wisconsin, however, grazing by livestock was found to compact soils, as well as to reduce the nitrogen and phosphorous levels (Steinbrenner, 1951).

Shoot consumption is deleterious to red and white oak reproduction in the Midwest and the eastern United States (Steinbrenner, 1951). Den Uh1 (1954) found that while oak leaves and buds are unpalatable to cattle, they will readily eat them when other forage is not available. He also found over-grazing to have a potentially irreversible impact on oak forests. Holland (1976) noted the lack of reproduction in a California white oak species, Quercus douglasii, and correlated this trend with heavy grazing of young shoots by cattle and sheep. Griffin (1977) summarized the lack of regeneration in California white oaks relative to live oaks and suggested differential palatability of these species to livestock and perhaps pocket gophers. Regardless, oak shoots contain 
little nutritional value (Smith, 1957) and Hall (1956) found little forage available in $\underline{Q}$. garryana woodlots.

Over-grazing by sheep and cattle has been widespread in the Pacific Northwest since the middle to late 19 th century (Galbraith, 1971). Due to the elimiation of open range by the Bureau of Land Management, this problem has considerably decreased since the early 20 th century (Cholis, 1952). Cattle are known to consume oak leaves heavy snowfall in 1861-62 forced farmers to cut down many oaks in the Willamette Valley as fodder for livestock (Thilenius, 1964) - but nothing is known about the direct effect of grazing on $\underline{Q}$. garryana regeneration.

Acorns are readily consumed by mammals, birds, and insects. The following animals eat $Q$. garryana acorns: western gray squirrel, Douglas' squirrel, racoon, black bear, porcupine, deer, elk, Steller's jay, acorn woodpecker, Lewis' woodpecker, scrub jay, common flicker, and wild turkey (Bakker, 1971; Horn, 1977; Ingles, 1965; Larrison, 1976). Korstian (1927) found that $90-100 \%$ of a year's mast production may be eaten by wildlife. He also observed few examples of acorns being stored and not later recovered. Verme (1953) noted that acorn consumption by wildlife had a deleterious effect on oak reproduction.

Oregon white oak leaves and bark are attacked by several insect species, including the western oak looper (Lambdina fiscellaria somniaria), several tent caterpillars, and numerous gall wasps. None, however, are considered serious pests (USDA, 1965). Verme (1953) noted a $78-100 \%$ rate of insect infestation in acorns.

Oregon white oak is not a valuable forest product. In pioneer days, it was fashioned into wagon rims, Eenceposts, chairs, doors, and 
used for general millwork (Gibson, 1913; Hanzlik, 1928). It is currently cut for firewood (Hall, 1956).

Another factor in plant ecology is vagility. The dynamics of the environment require that even sessile species periodically migrate or perish. And rooted organisms, which produce progeny only at their doorstep, invite intense intraspecific competiton (Janzen, 1970). Hence selective pressures operate for effective seed dispersal mechanisms. Organisms which produce microscopic spores in large quantities have little problem distributing their progeny hither and thither, and are often broadly distributed, e.g. certain fungi (E1ton, 1958). Acorns, while large and heavy, have several potentials of dispersal, including: falling off the tree and bouncing or rolling downslope; dropping in a stream and floating to a safe site; or being carried by an animal to a safe location. The first possibility only occurs on slopes. Verme (1953) noted that the majority of acorns are produced around the periphery of the crown, thus ensuring that they will fall the maximum distance from the parent tree. It would be of further advantage if open crown or border trees produced more seeds than interior trees. While this does occur in some species (Kramer, 1960), it is not always the case in oaks (Verme, 1953).

Transport by flotation is probably not very important. Crocker (1953) noted that acorns have a low longevity; while some can withstand prolonged soaking, most die quickly (Kramer, 1960). In addition, white oak acorns do not float well due to a high specific gravity (Korstian, 1927). Ridley (1930), however, believes that acorn flotation is a viable means of dispersal in rivers, but not in the ocean.

Animal transport is probably the most effective mode of acorn 
dispersal. The nut is selectively carried for some distance and deposited in a similar habitat which is frequently conducive to seed germination (Cruden, 1966). In North Carolina, animals tend to carry viable rather than infested acorns. As noted, however, this value may be negated by animals with a high rate of seed retrieval (Koristan, 1927). In California, scrub jays are important vectors of acorn dispersal:

The Scrub Jay...taking the role of the competent nurseryman as he places the acorns in the substrate most suitable for their germination, mineral soil under duff. (Bakker, 1971, p. 118).

Squirrels also place acorns in safe sites:

Gray squirrels are important and beneficial animals in reforestation in the Valley Oak Association... (Ingles, 1956, p. 157).

The role of humans in the distribution of acorns is not documented. The high correlation in eastern Oregon and Washington of Indian camps located within oak stands, however, has been noted as a possible cause and effect relationship (Ross, 1975). 


\section{SITE DESCRIPTION}

The study is limited to Wasco and Hood River Counties in Oregon (Figure 2) and is found within "The Dalles" United States Geological Survey quadrangle. The oak population grades from the mesic plant associations of the Columbia River Gorge east to the borders of the central Oregon desert. Either or both sides of the Columbia River could have been chosen for this study; the Oregon side was selected for convenience.

\section{GEOLOGY}

The study area is found at the junction of the Deschutes-Umatilla Plateau and the Cascade Mountains. It is dominated by $1600 \mathrm{~m}$ deep Miocene-Pliocene flows of Columbia River basalt which has weathered little in this arid climate (McKee, 1972). Overlying these basalt layers are Pliocene-aged alluvial deposits of silt, sandstone and conglomerates. These occur linearly along the Columbia River, occurring sporadically throughout the study area. At the western edge of the Dalles Formation occur the recent (Pliocene-Holocene) Cascade lavas, which consist of volcanic flows and a single cinder cone within the study area (Baldwin, 1959; Newcomb, 1969).

\section{CLIMATE}

The climate changes dramatically as one passes through the Columbia River Gorge from west to east. Annual precipitation plunges from over $1900 \mathrm{~mm}$ in the Cascades to less than $240 \mathrm{~mm}$ at sites in Wasco County. 


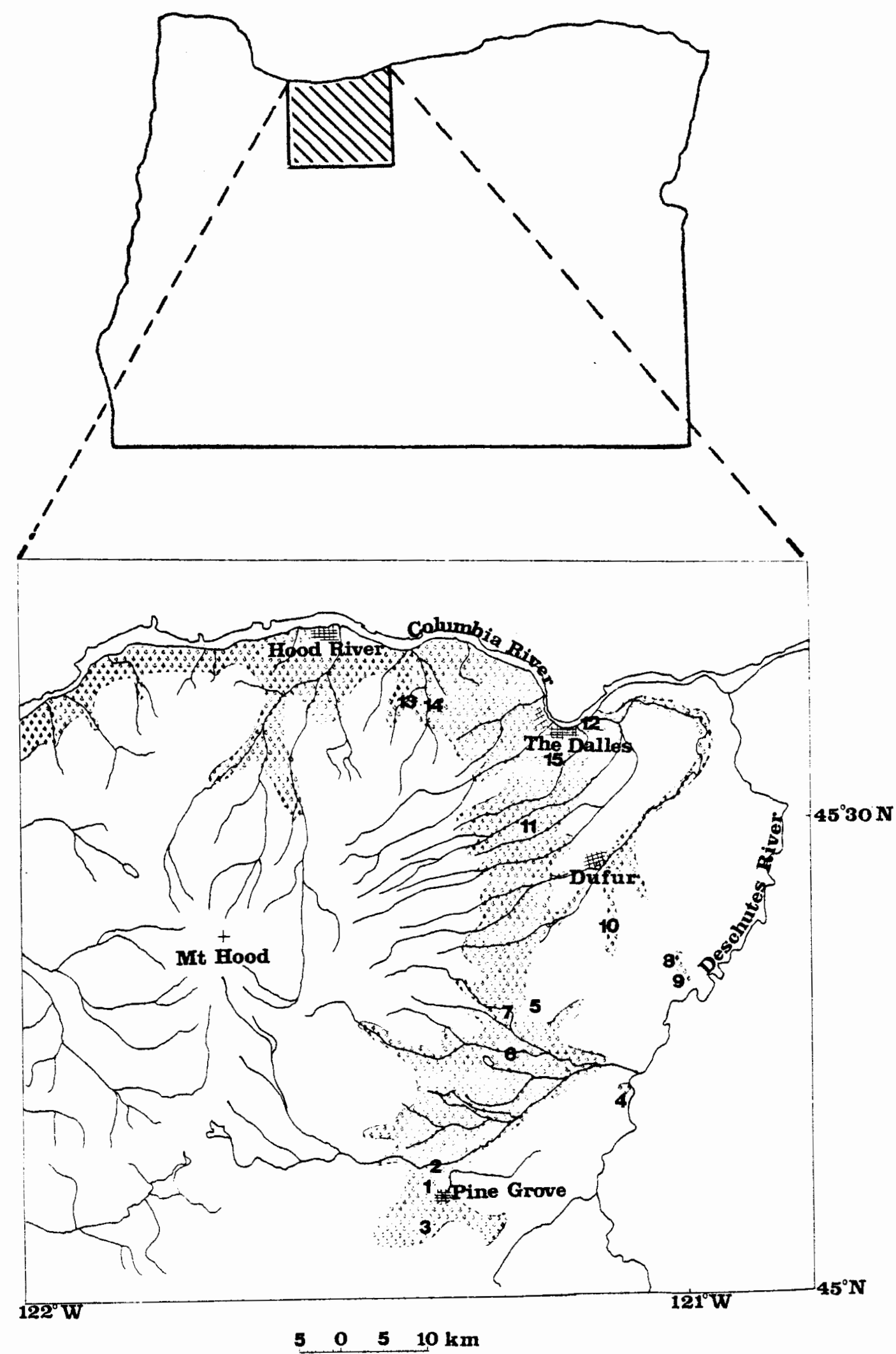

Figure 2. The distribution of Oregon white oak in north-central oregon. The numbers represent the location of study sites (Table 1). 
The rainfall regime moves from a definite winter maximum to a more uniform seasonal precipitation regime. Temperatures can be intensely hot in the summer and bitterly cold in the winter. Basically, the climatic shift is from a west coast marine climate to a more contental climatic regime.

\section{VEGETATION}

Detling (1958, 1960) studied the vegetation associations within the Columbia River Gorge. He found that the north facing (Oregon) side of the Gorge changes from a mesic, coniferous forest on the western slopes of the Cascades to a xeric vegetation association in the east. The mesic association includes such dominants as Douglas fir (Pseudotsuga menziesii), western hemlock (Tsuga heterophyla) and western red cedar (Thuja plicata). The eastern assemblage dominants consist of western juniper (Juniperus occidentalis), big sagebrush (Artemisia tridentata) and many species of native and introduced grasses, such as blue-bunch wheat grass (Agropyron spicatum) and Russian cheatgrass (Bromus tectorum). The Quercus garryana association, including such species as snowberry (Symphoricarpos albus) and poison oak (Rhus diversiloba), is a member of and forms an ecotone between these converging associations (see Figure 3).

\section{LAND USE}

The land use of this area has changed considerably since white settlement. Before 1850, the Wasco-Wishram Indians gained their livelihood from salmon fishing and trading along the Columbia River. After their displacement in the 1.850s. cattle grazing quickly spread through- 


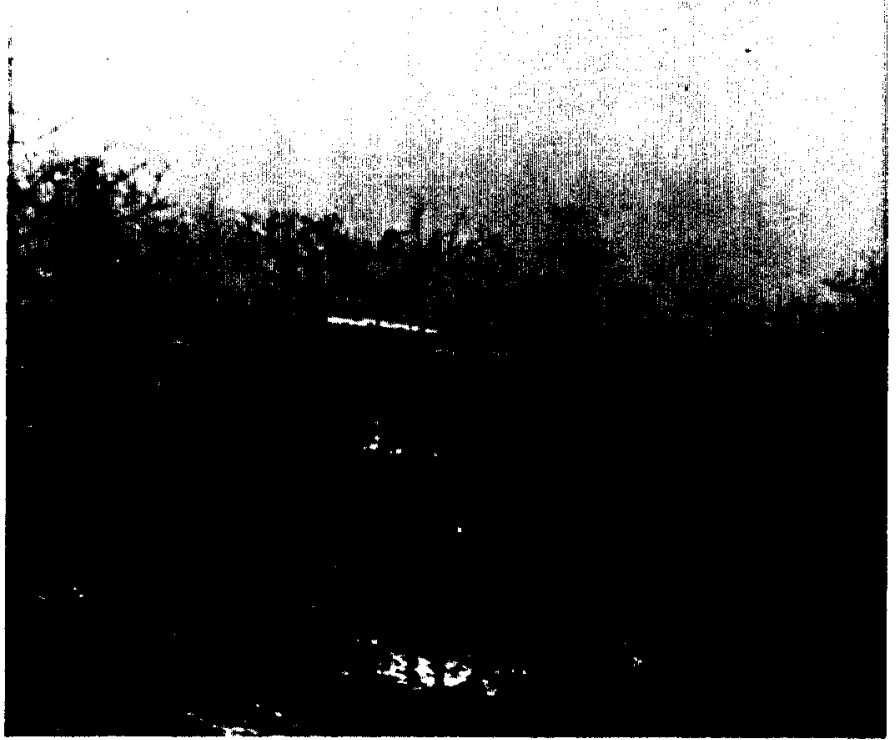

Figure 3. Oregon white oak forms pure stands between Ionglas fir/ponderosa pine and sagebrush/juniper/grassland associations. 
out eastern Oregon. With the arrival of sheep ranching operations, conflicts over grazing rights inevitably led to range wars. Wheat farming, which was introduced in the 1860 s, remained a small contributor to the economy until railroads opened up inexpensive freight transport to Portland in the 1880s. Currently, wheat farming, cattle grazing, and forestry dominate the economic landscape east of the Cascades (Brogan, 1964). 


\section{CHAPTER IV}

\section{METHODOLOGY}

The first step in distribution synthesis is accurate mapping. This information was garnered by driving and walking over much of Wasco and Hood River Counties. Populations of oak were plotted on a $1: 125,000$ topographic map (Figure 2). Q. garryana stands were found to be sporadically distributed over the area. Thus sites within the designated oak range may be devoid of individual trees.

I attempted to use Soil Conservation Service air photos to map the distribution of oaks. The available scale, however, was too small to discriminate oaks from other deciduous trees.

In order to calculate the age of oak size-classes, fifteen oaks were cored with a hand increment corer* The cores were inserted into plastic straws, labeled with site characteristics and the tree diameter, later mounted on flat pieces of wood, and finally sanded and coated with linseed oil to bring out the tree rings. Annual secondary xylem additions were counted with the aid of a dissecting microscope.

The age of each tree was then plotted against its diameter on a simple scattergram. The resultant line of positive regression was evaluated for statistical significance. Then, in order to predict the age of tree size-classes and individual trees, inverse predicitions - interpreting abscissa points from ordinate points - were calculated, including $95 \%$ confidence limits.

${ }^{*} Q$. Garryana contracts heart rot after an unspecified age, thus rendering tree ring counting impossible, and was found to tenaciously resist penetration by an increment corer. 
The size-structures of fifteen sites were determined by linequadrat analyses. Both pure and mixed stands of Oregon white oak and conifers were surveyed. The starting point for each transect was randomly chosen using a table of random numbers or numbered slips of paper picked from a hat. If the population was small, the line intersecting the greatest part of the stand was chosen. In one particularly small stand, each tree was measured. By cueing on a distant object as a reference point, a fairly straight line could be maintained with a Brunton Compass. Circular quadrats were spaced every $10 \mathrm{~m}$ along this line. Stakes with a 3-5 $\mathrm{m}$ length of attached rope were inserted into the ground. The rope was stretched from the stake and walked around the periphery of its length, thus enclosing a 6-10 m diameter circle. Each tree was measured with a dbh (diameter at breast height) tape which converted the circumference to a diameter-in-centimeters figure. Any tree trunk that touched the circulated rope was counted in; consequent1y, density estimates should run slightly high. Dead trees and stumps were not counted.

The afore-mentioned method was used throughout the study, with the exception of one site which was surveyed using a grid quadrat method (see site 3 ). In this case, $200 \mathrm{~m}$ were marked off in $20 \mathrm{~m}$ intervals in a north-south direction; then $100 \mathrm{~m}$ in $10 \mathrm{~m}$ intervals in an eastwest direction. Using a table of random numbers, stakes were placed at the intersection of selected grid lines. Circular quadrats were then applied and the size-structure data were gathered.

Trunk measurements were made at $0.7 \mathrm{~m}$ up from the ground. The decision as to whether the growth represented one or more trees was sometimes arbitrary due to oak's habit of separating into 2 or more 
trunks. Trees less than $2 \mathrm{~cm}$ in diameter were counted as seedlings, with no reflection of genesis intended (often, regeneration is stump rather than seed generated).

Historic climatic data were extracted from the U.S. Climatological Register for 4 stations in the study area. Temperature and precipitation figures are plotted as running mean fluctuations about the mean (0) Iine for comparison to the oak size-structures.

Plant identification follows Hitchcock and Cronquist's Flora of the Pacific Northwest. Flowering had passed in most species, making positive identification difficult. Thus, only easily identified plants were recorded (see Appendix I).

In order to measure the distances traveled by falling acorns, an oak was selected in Novemeber 1977 and as many living acorns as could be reached were painted with silver nitrate $\left(\mathrm{AgNO}_{3}\right)$. This compound, however, did not visibly stain the acorns. Another tree was chosen and its acorns were painted with red spray paint. The following spring, the painted acorns were relocated and mapped relative to the parent tree.

In order to determine the effectiveness of animals as vectors of seed dispersal, the distances acorns were carried before being dropped, stored, or eaten were roughly calculated for birds and mammals. Potential rates of oak population migration were estimated from these results. A cursory bird survey was also conducted (see Appendix II). 


\section{CHAPTER V}

\section{OREGON WHITE OAK'S POPULATION STATUS}

\section{INTRODUCTION}

In natural populations, more organisms are produced than can be expected to reach maturity. Annual mast production in oaks is thus quickly decimated by physical intolerance and predation. As a consequence, the number of individuals surviving from one age-class to the next decreases at a fairly constant rate. This phenomena is visually demonstrated by separating the members of a population into successive age-classes and graphing the data as a simple regression. Such a representation will conform to a gently sloping "reverse $J$ curve" if the population is in a state of reproductive equilibrium. If reproduction is relatively high or low for a period, however, the regression curve should exhibit an aberration from the norm. It should be possible, then, to estimate the reproductive status of a population and, further, where gross reproductive changes are evident, to identify the chief environmental factors responsible (Hett, 1971; Hett and Louks, 1971; Johnson and Risser, 1975; Leak, 1965).

The reproductive equilibrium method of population evaluation must be applied cautiously. Only climax species will conform to a reverse $\mathrm{J}$ curve; a seral species such as Douglas fir, which cannot reproduce under its own canopy, will not conform to this model. Oregon white oak will be temporarily treated as a climax species in the study area, although it may be a successionary species in other parts of its range. Its climax status will be further considered in light of the size-structure results. 
Another potential problem is that the negative regression slope will naturally vary between different species. Whereas organisms with short life spans require copious annual reproduction in order to survive, long-lived species may be adapted to less frequent and abundant productions of progeny. Thus, the evaluation of size-structure anomolies in a long-1ived tree like $Q$. garryana must be limited to lengthy or radical perturbations from the norm.

Finally, subtle accumulative changes in the environment, while increasingly depressing reproduction in an organism, may not be revealed in a size-structure evaluation. Since there is no standard regression for comparison, populations on the road to extirpation may appear to be heal thy.

OAK SIZE-STRUCTURE DATA

In order to discern the reproductive status of the central Oregon Q. garryana population, circular quadrats on line transects were used to sample tree diameters at fifteen sites. The site characteristics are recorded in Table $I$, the tree diameters divided into size-classes in Table II, and graphed in Figures 4-25.

\section{DISCUSSION}

Oregon white oak's population status appears to be blurred rather than clarified by the greatly varying size-structure data. This is because the results include data from both the arid and moist limits of oak's range. Thus, changing environmental conditions, which elicit opposite regeneration responses from sites at the Douglas fir ecotone and the juniper/sagebrush ecotone, are expected to produce contrasting 


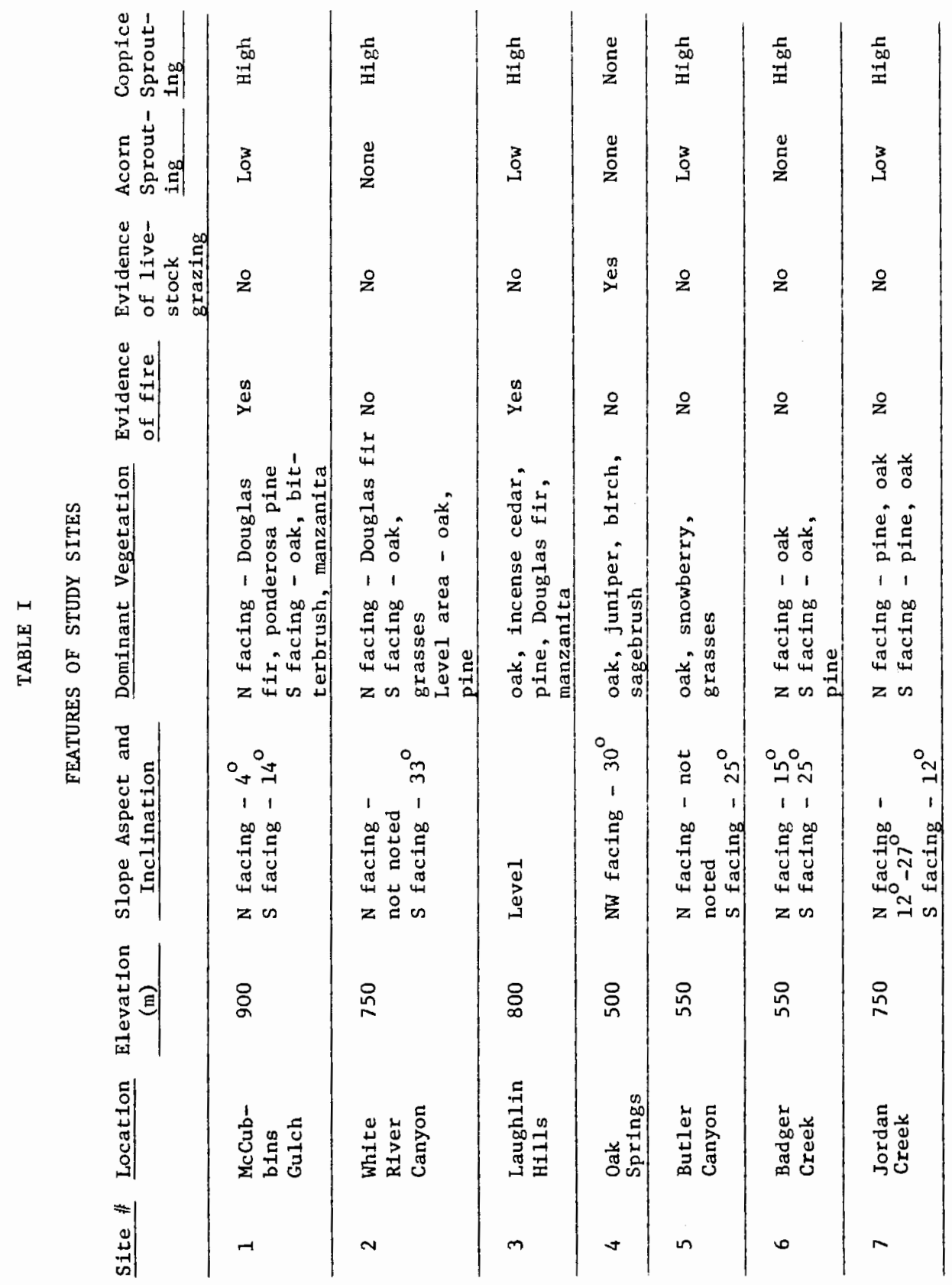




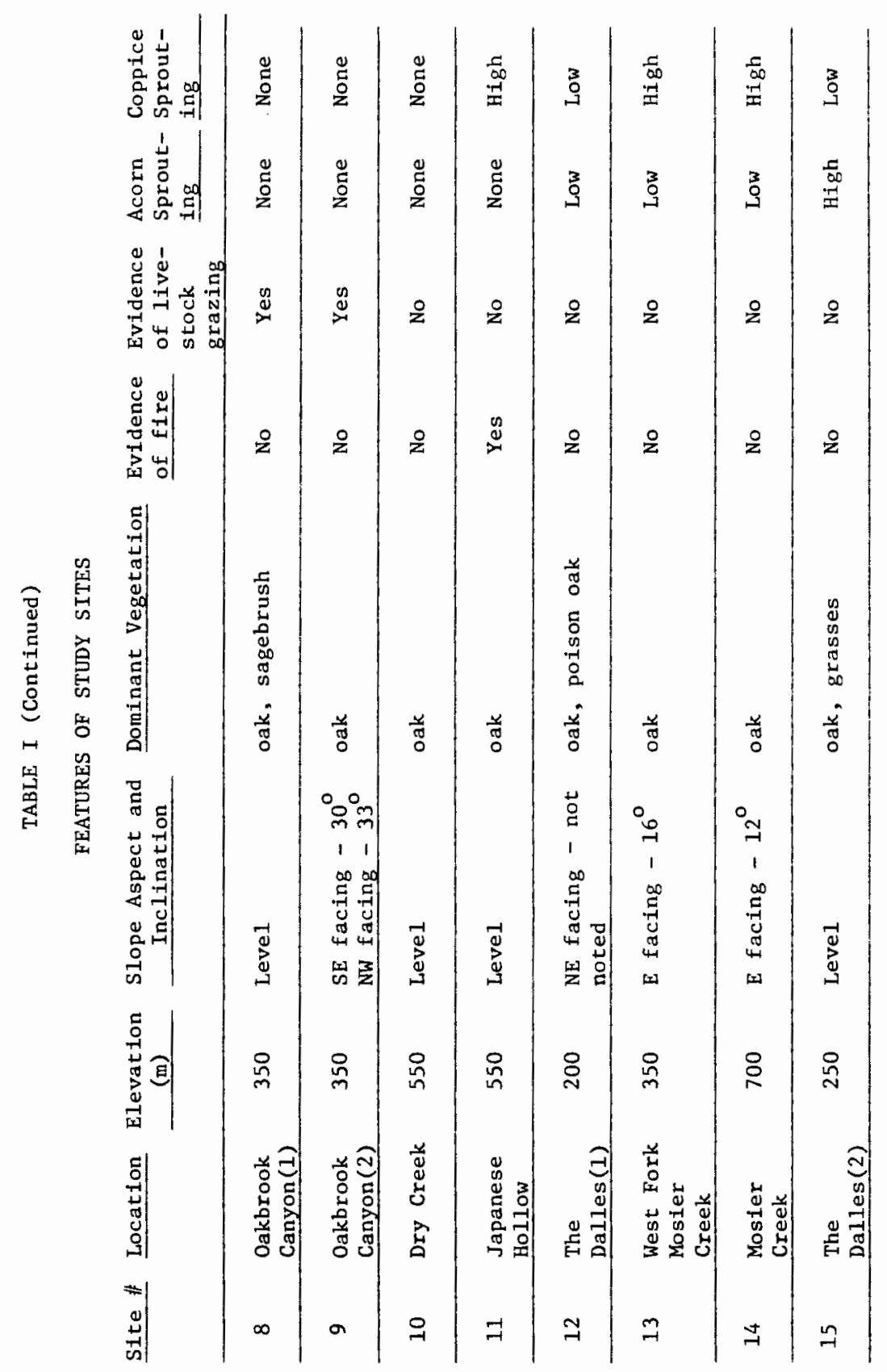




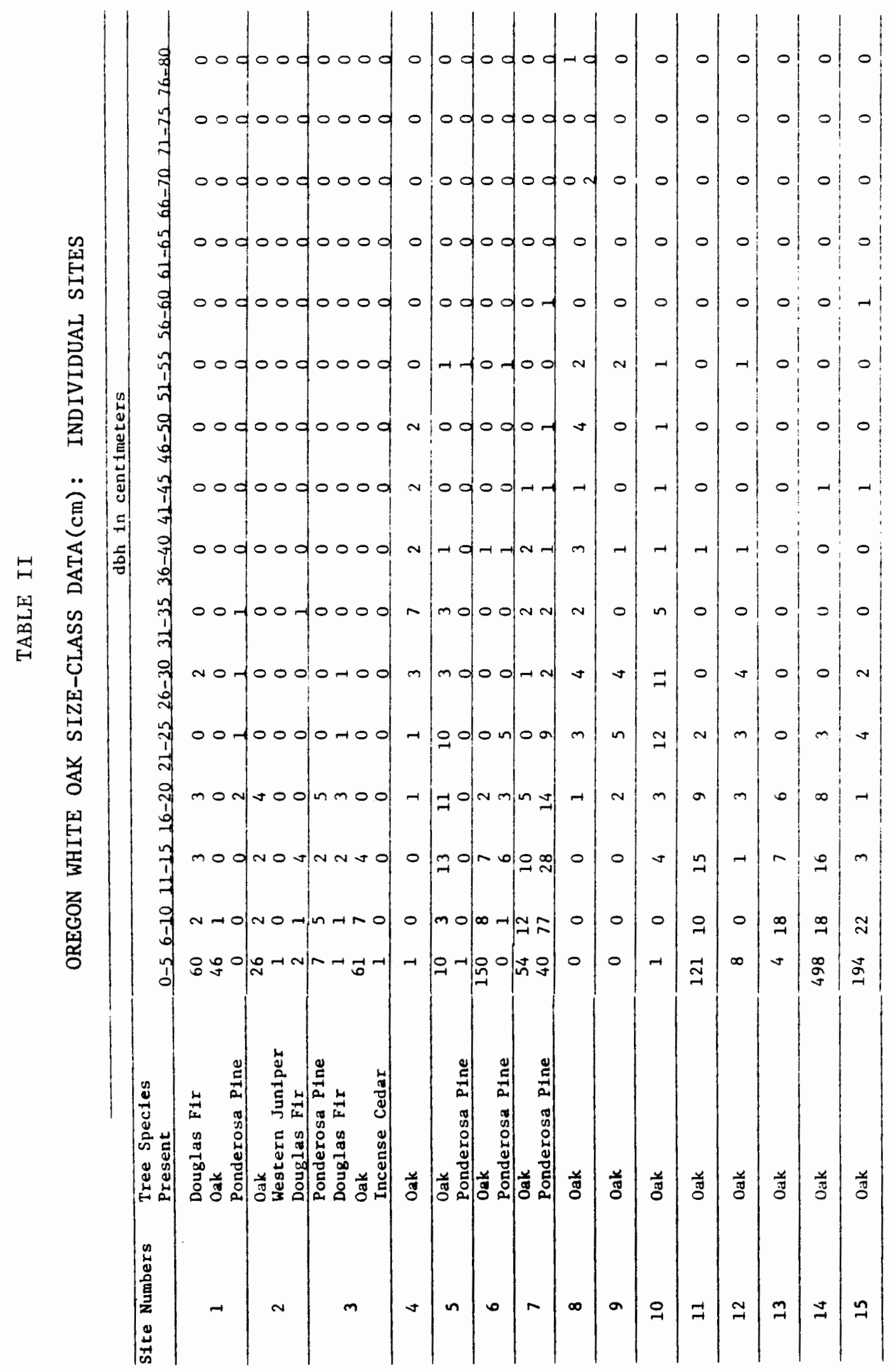




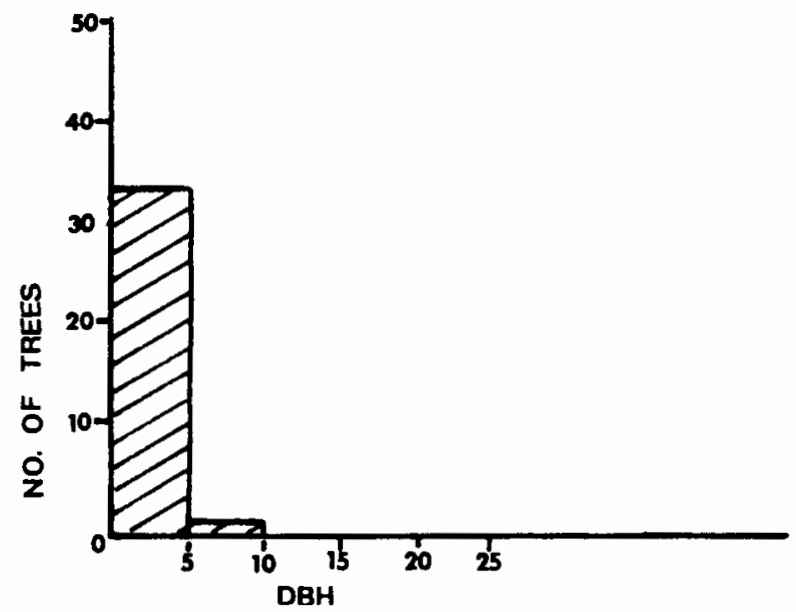

Figure 4. Q. garryana's population size-structure at site \#1.

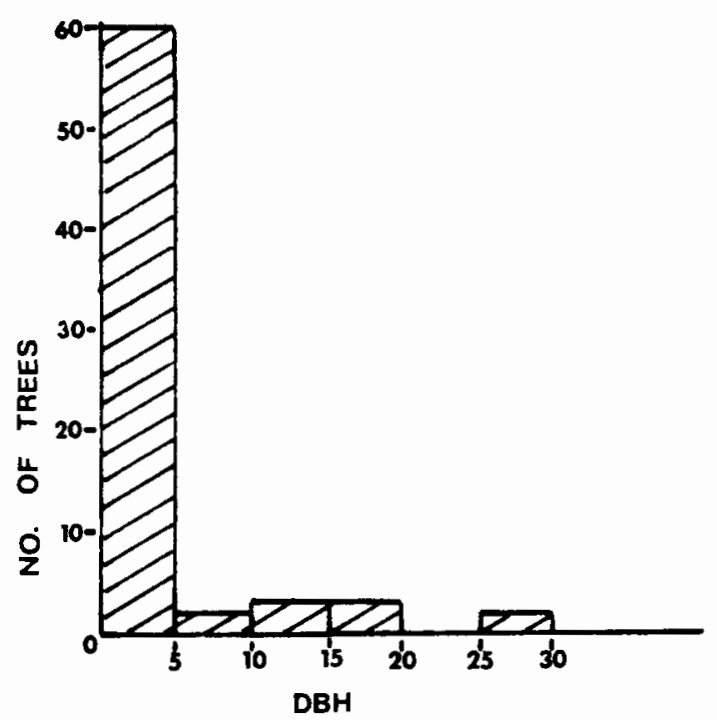

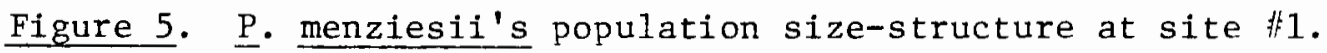

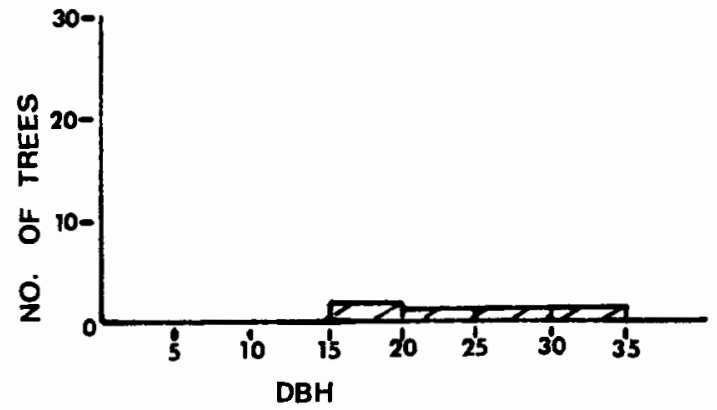

Figure 6. P. ponderosa's population size-structure at site \#1. . 


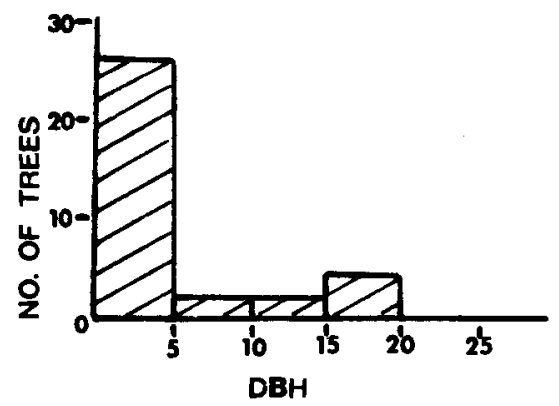

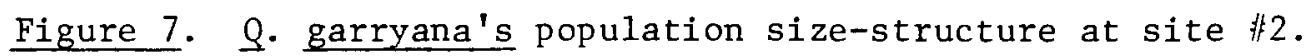
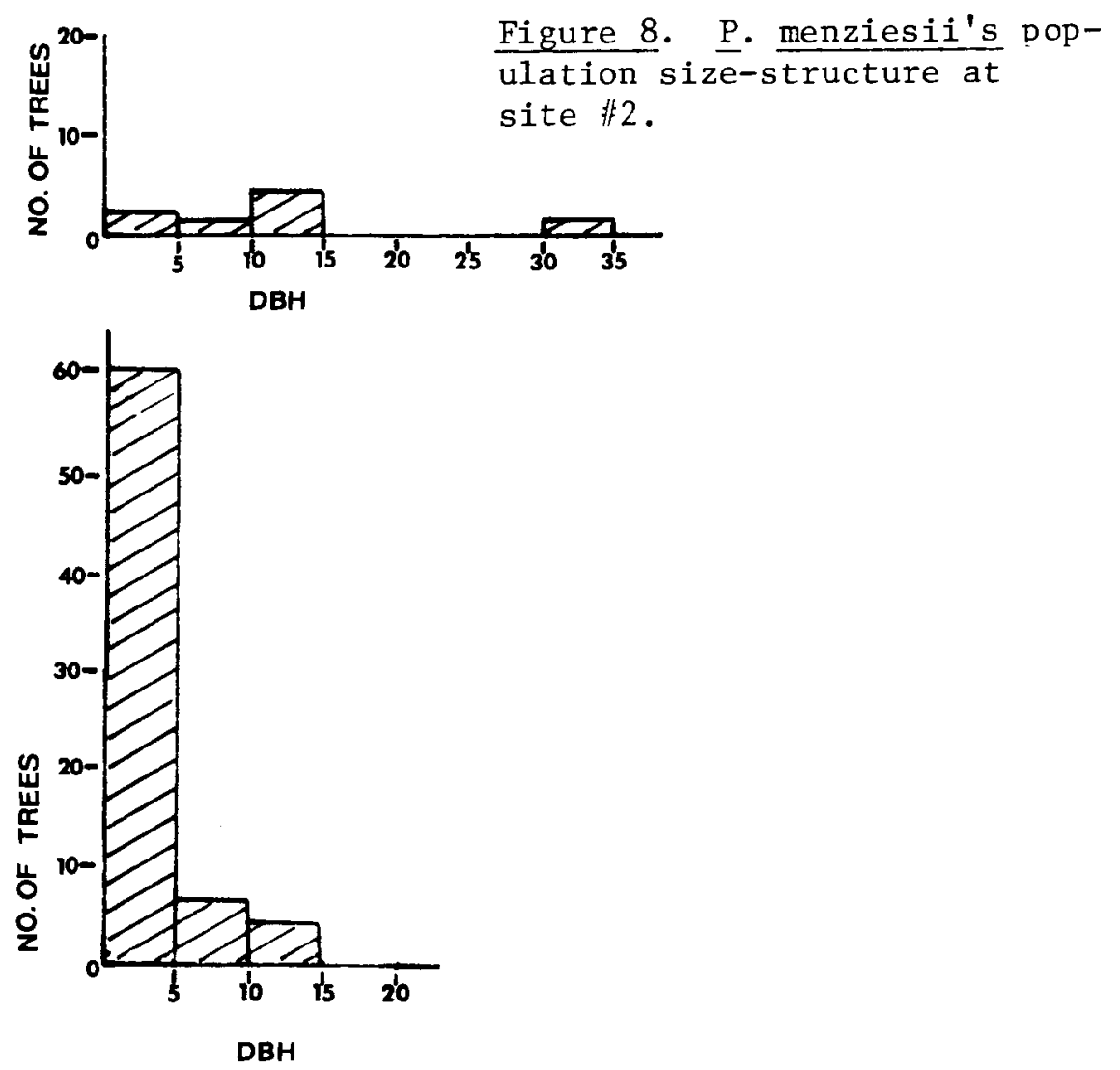

Figure 9. Q. garryana's population size-structure at site 非 3 . 


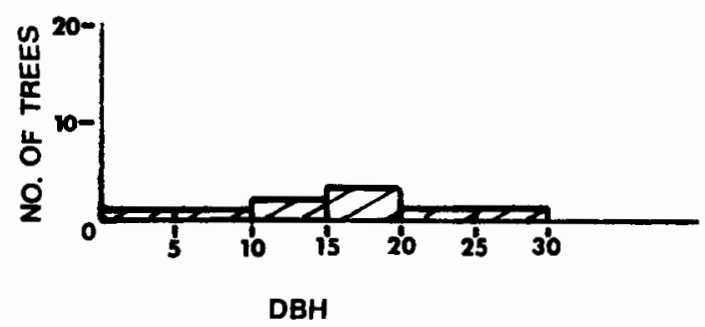

Figure 10. P. menziesii's population size-structure at site 非.

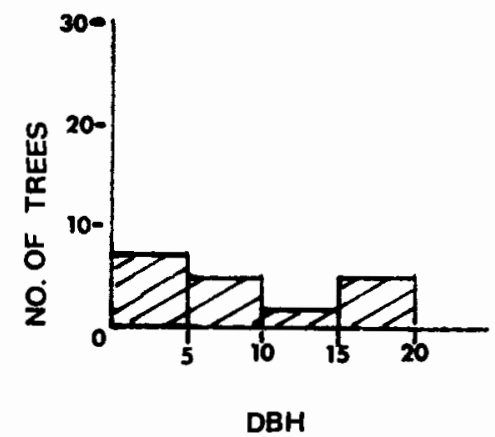

Figure 11. P. ponderosa's population size-structure at site 3 .

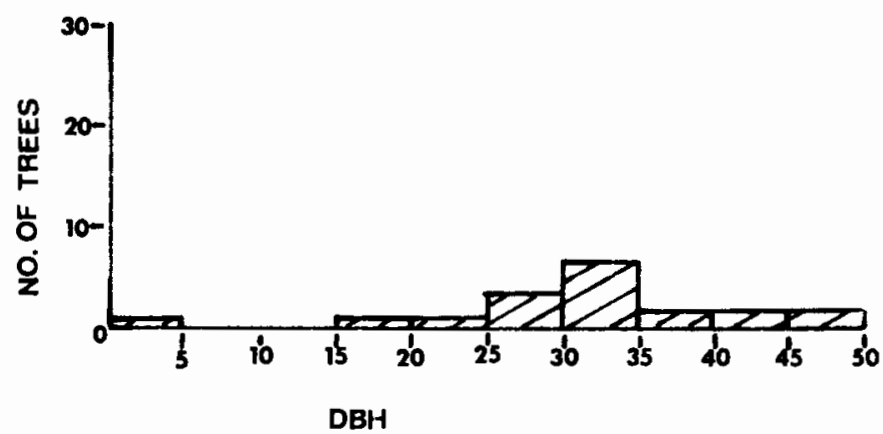

Figure 12. Q. garryana's population size-structure at site $\$$. 4 . 
31
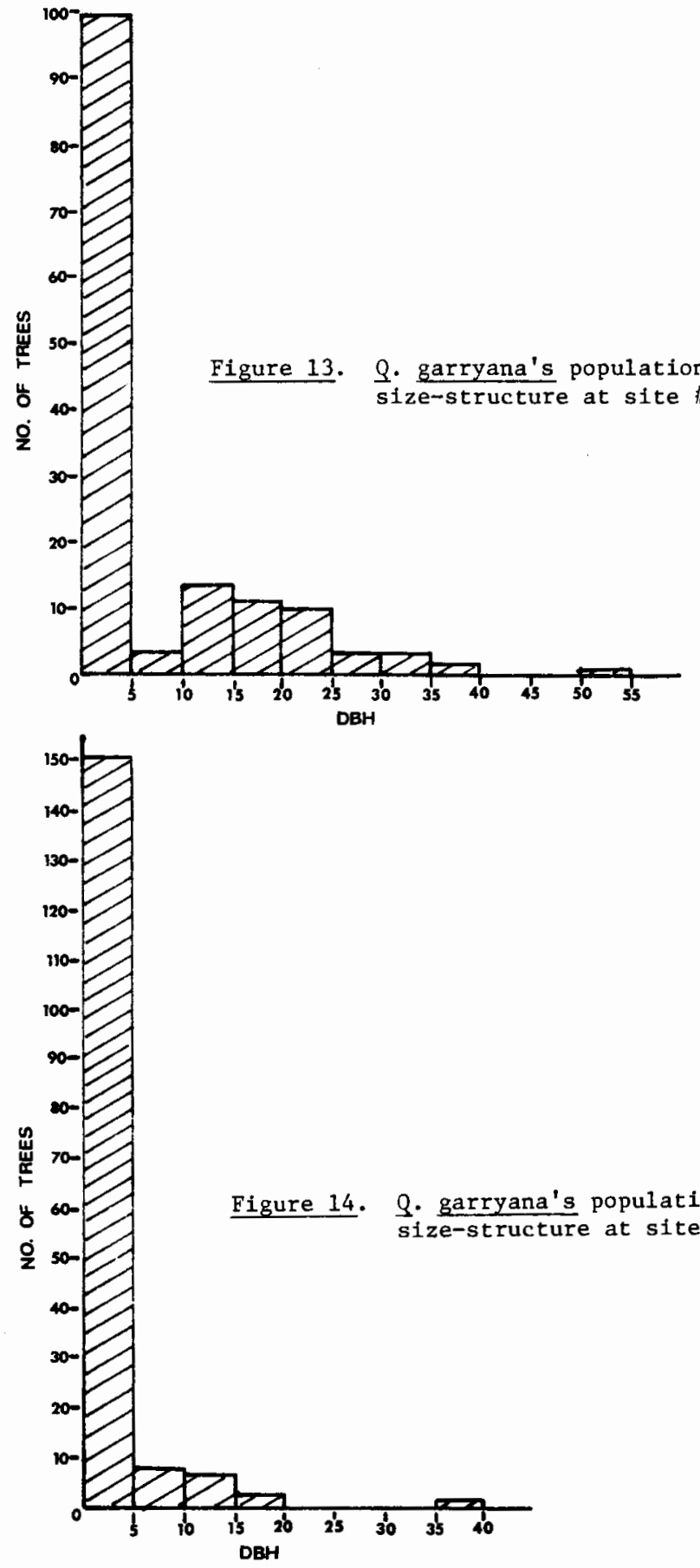


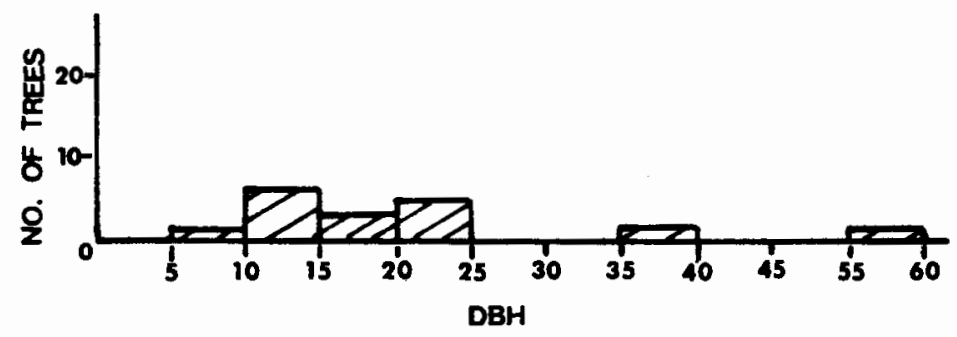

Figure 15. P. ponderosa's population size-structure at site $\$ 6$.
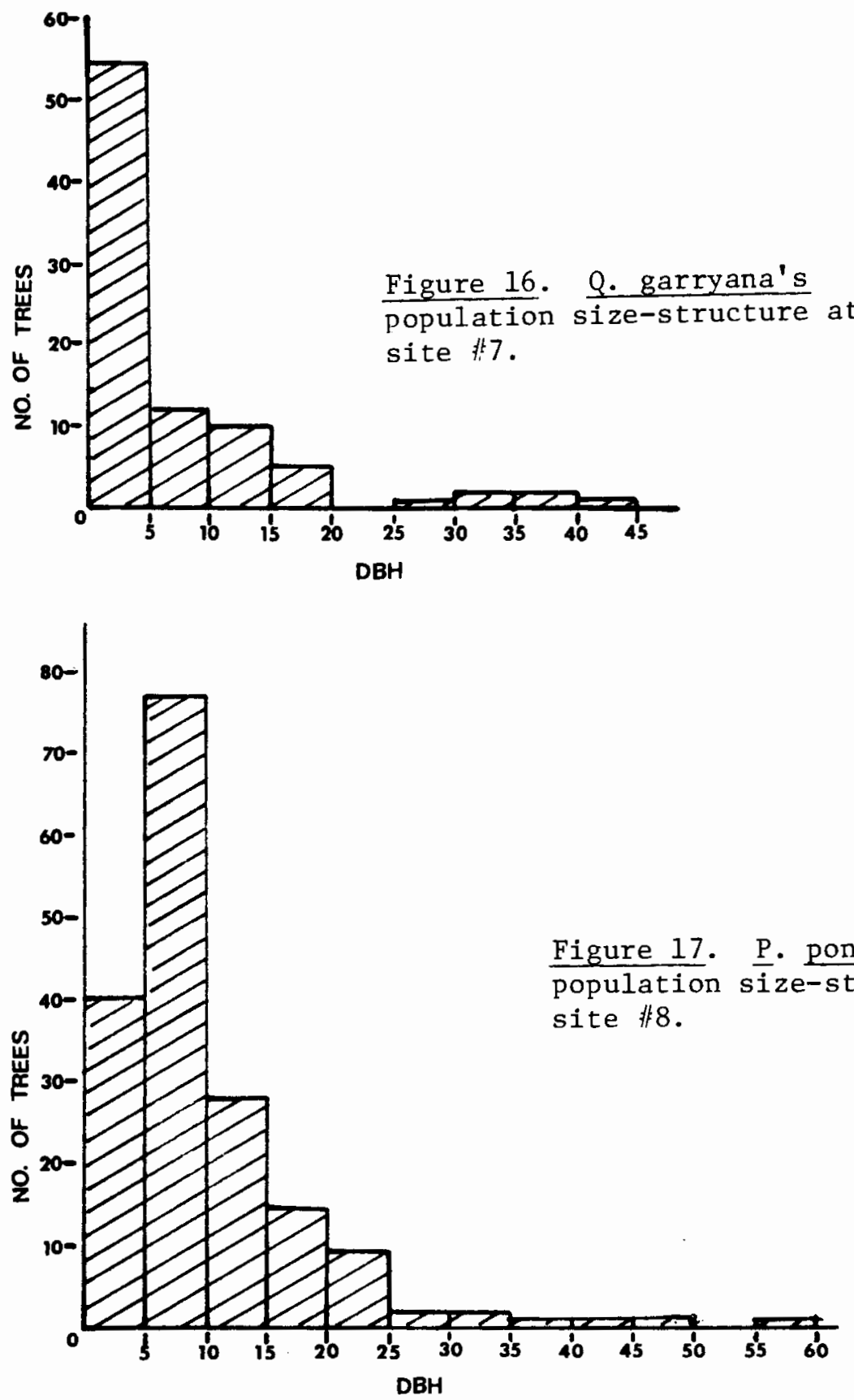


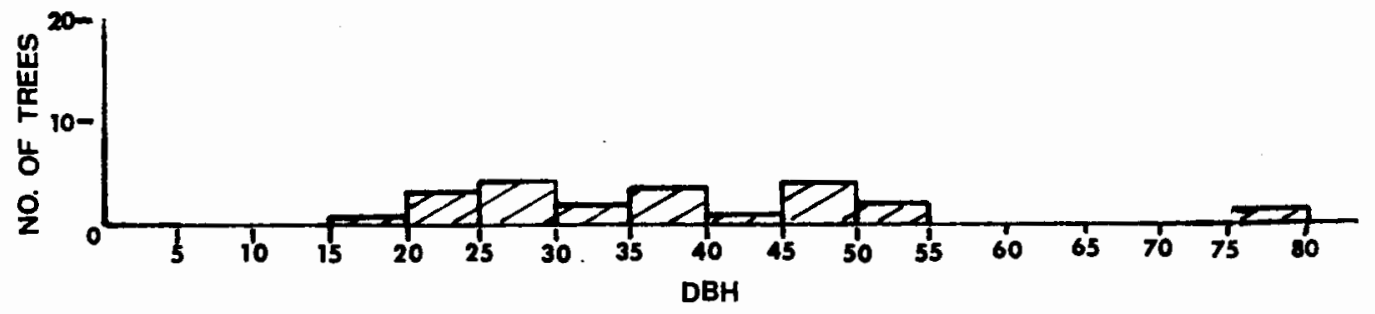

Figure 18. Q. garryana's population size-structure at site

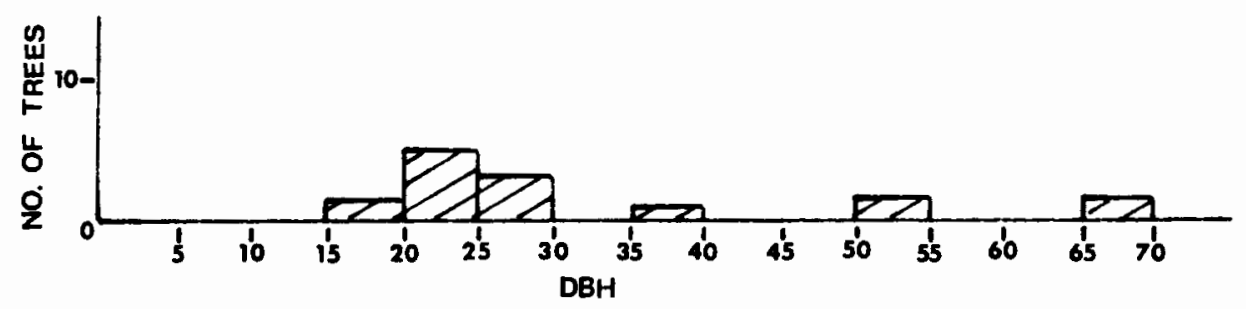

Figure 19. Q. garryana's population size-structure at site $\$ 9$.

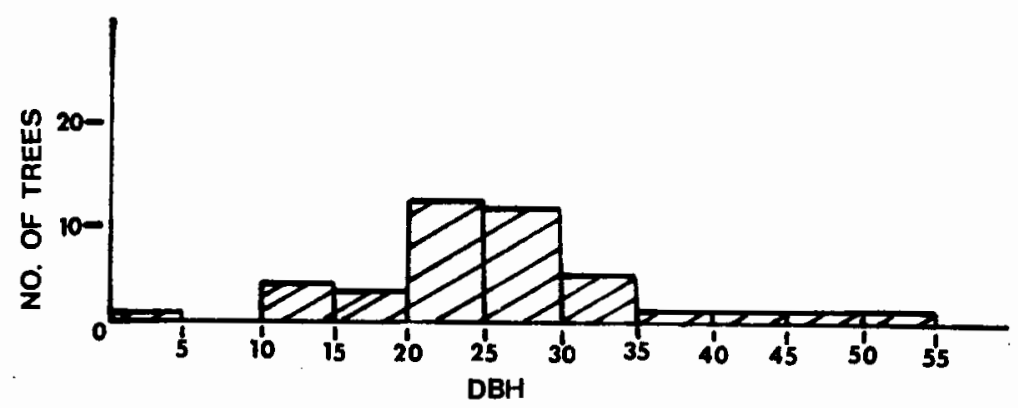

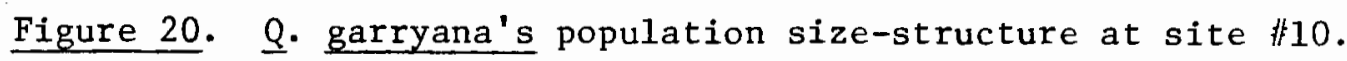


34

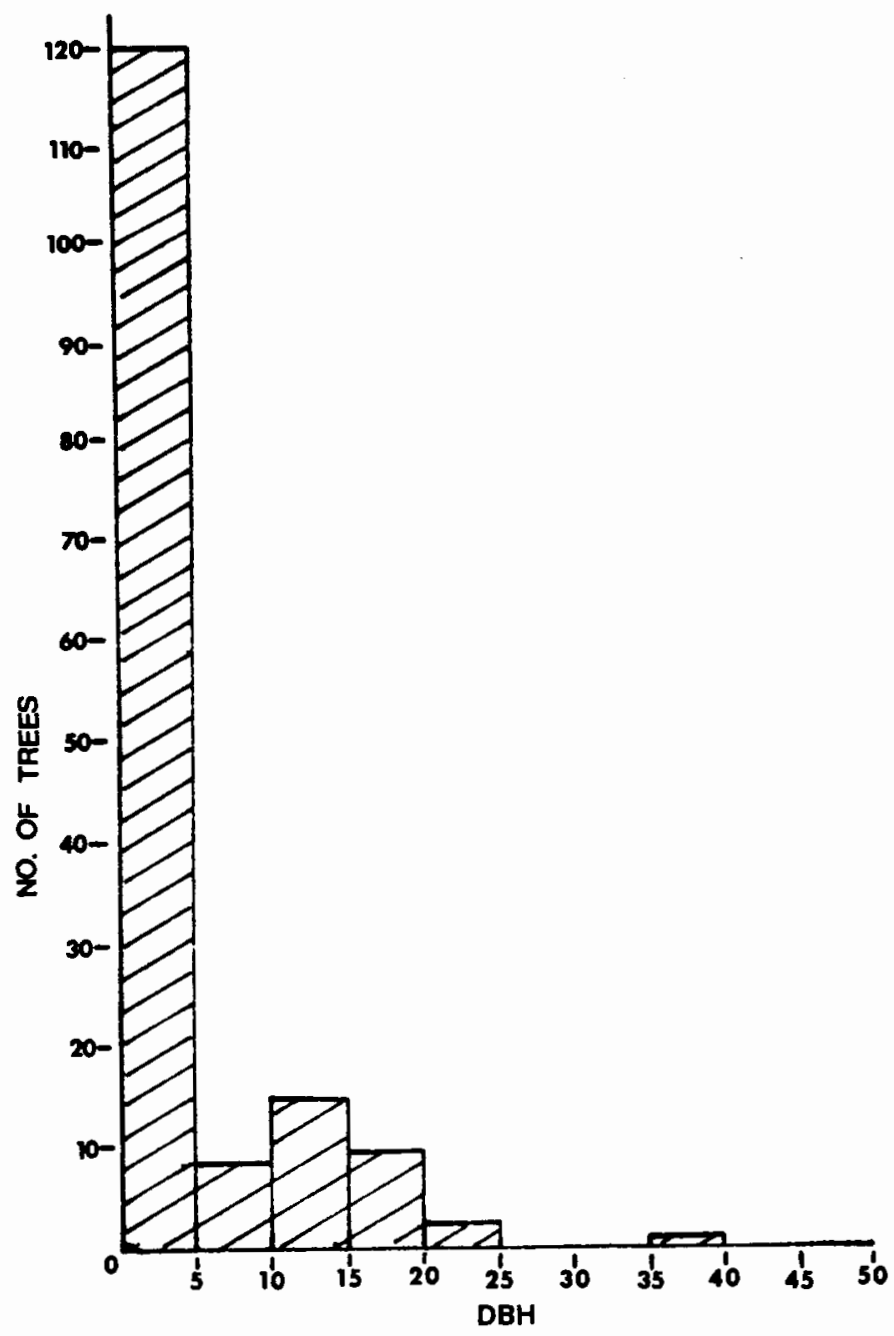

Figure 21. Q. garryana's population size-structure at site \#11.

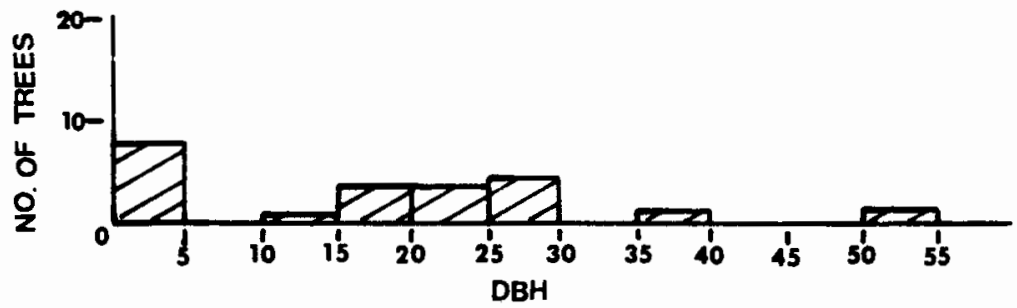

Figure 22. Q. garryana's population size-structure at site $\|_{12}$.

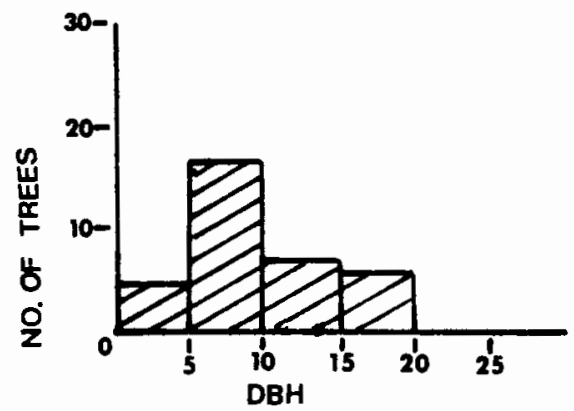

Figure 23. Q. garryana's population size-structure at site 非13. 
35

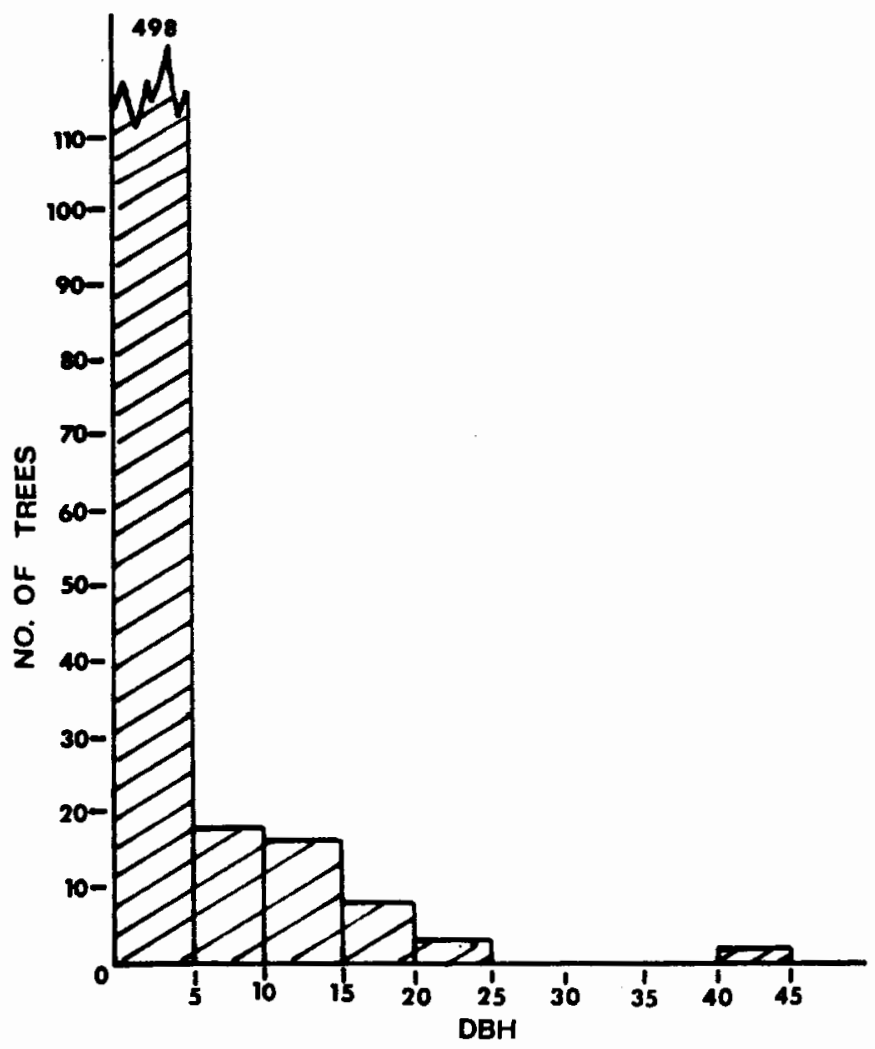

Figure 24. Q. garryana's population size-structure at site 非14.

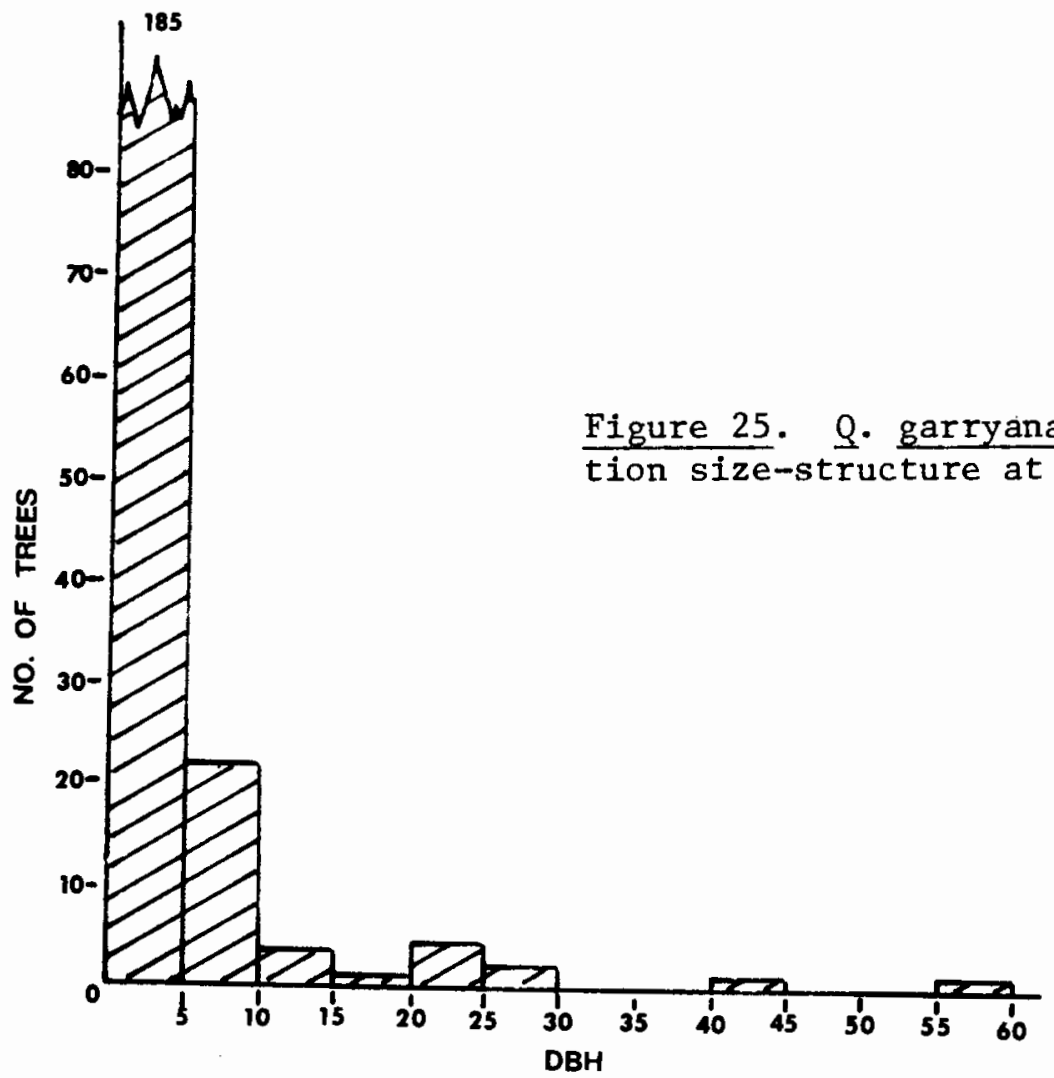


size-structure results.

Field observations revealed that differences in slope aspect were a major factor in oak distribution. Oak populations on south facing slopes, due to reduced effective precipitation and greater temperature variation, reveal very different size-structures than adjacent north facing slopes. In order to later evaluate this factor, the data for sites on north and south facing slopes are separated in Table III and graphed in Figures 26 and 27.

The overall picture of oak's population status is revealed by graphing the summed size-class data for all of the sites (Table III and Figure 28). The size-structure conforms to a reverse $\mathrm{J}$ curve; thus Oregon white oak's total central Oregon population is in reproductive equilibrium.

There is no evidence to indicate that oak is expanding its range. In order for this to occur, it is necessary for acorns to be transported to a safe site and germinate beyond oak's present range. No young populations of $Q$. garryana were located, nor does oak seem to be regenerating by acorns at this time. As noted in Table I, regeneration is being largely accomplished through coppice sprouting, an adaption to stress, especially fire. The causes of this lack of seed regeneration are not immediately evident, as there seems to be sporadically abundant mast production.

There is some indication that oak is being reduced in extent at its arid periphery. Figures 12, 18, and 19 describe disjunct, arid frontier populations exhibiting no recent regeneration. This situation, however, appears to be a by-product of human land use practices rather than environmental change and will be discussed later. 


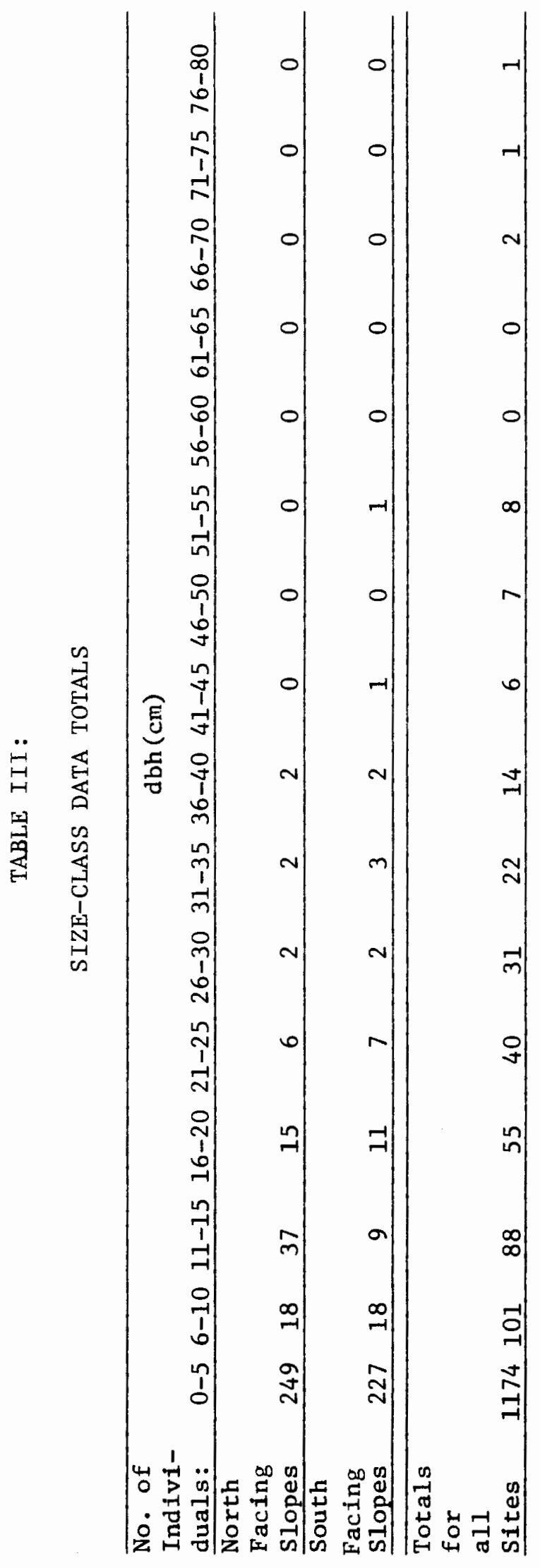




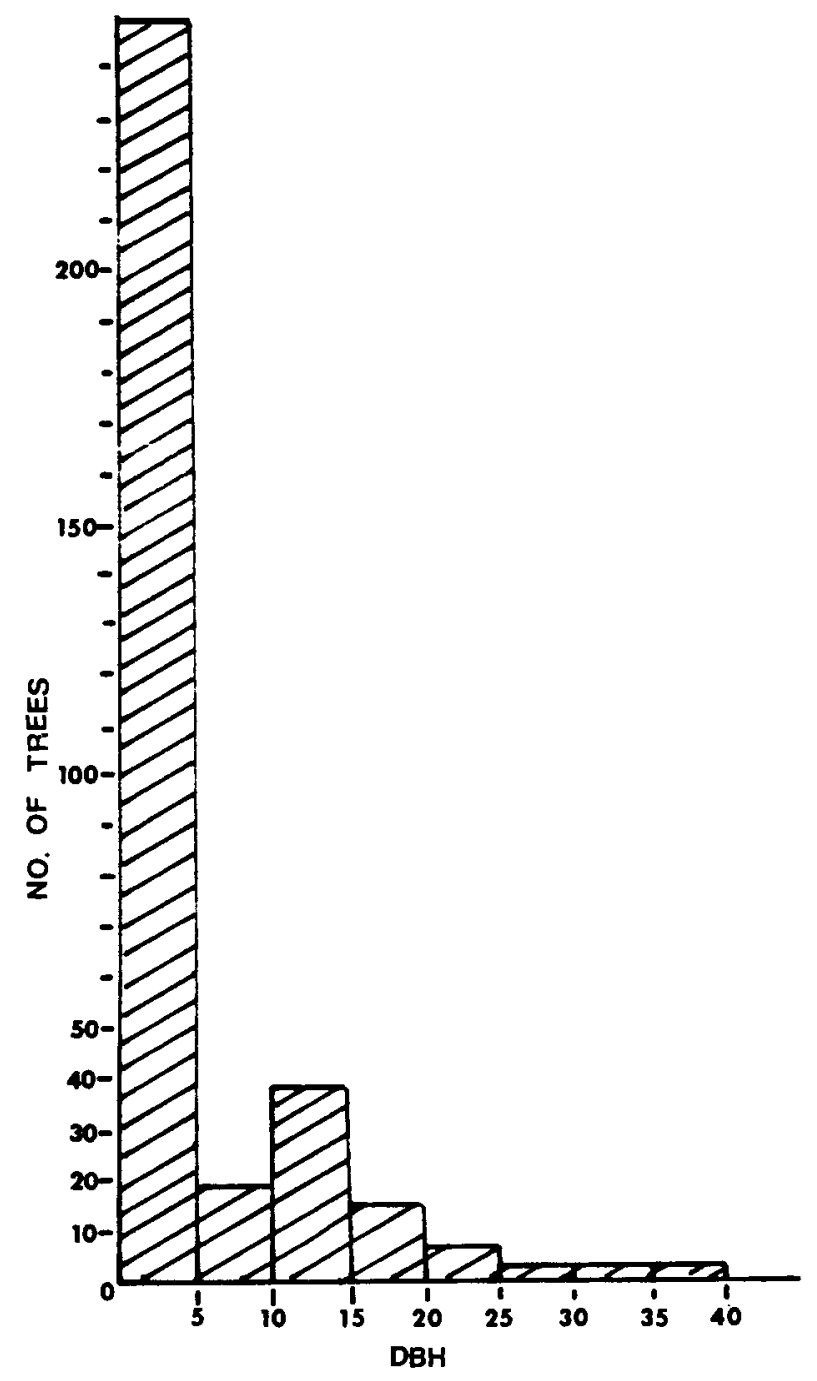

Figure 26. Q. garryana's population size-structure for sites located on north-facing slopes. 


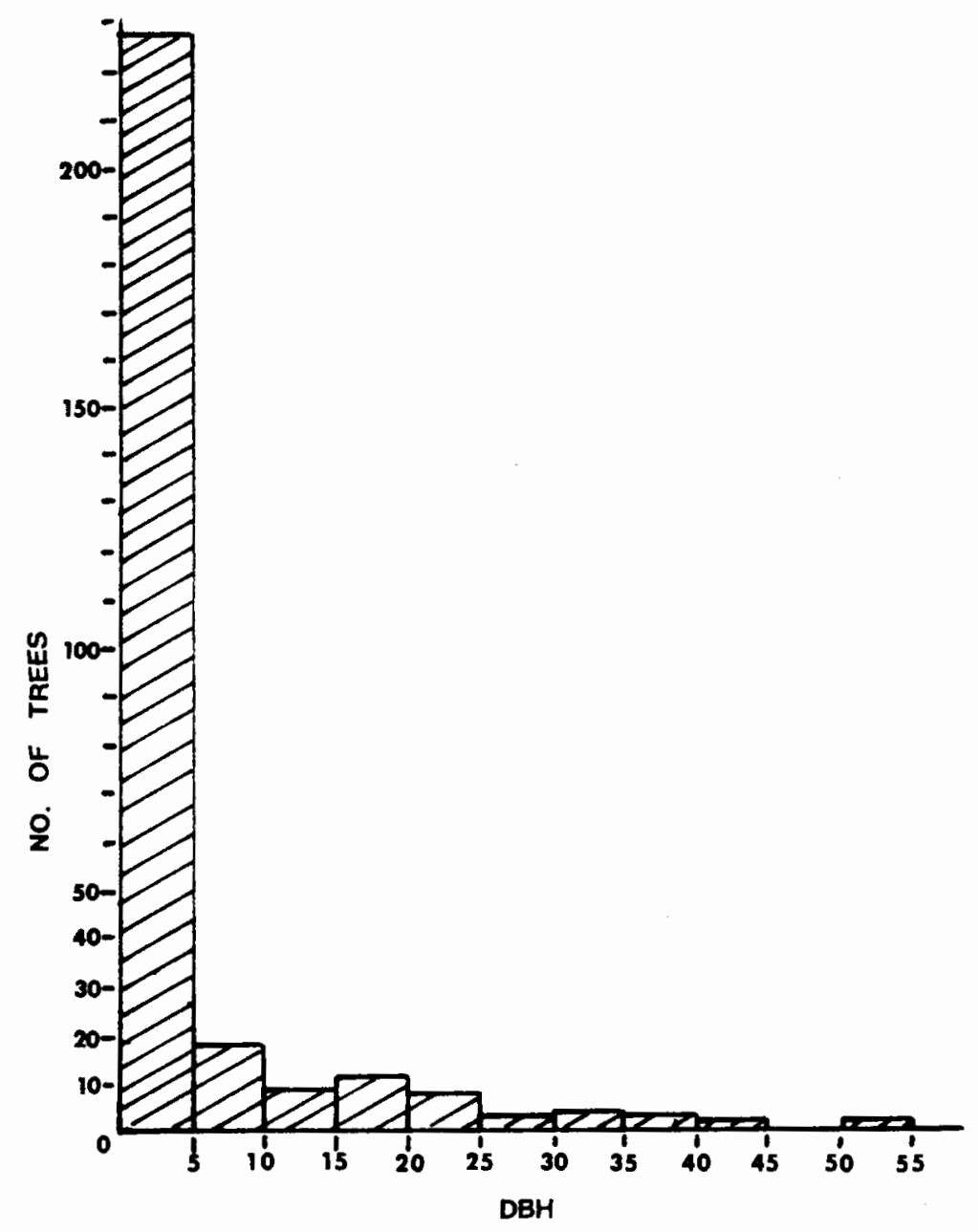

Figure 27. Q. garryana's population size-structure for sites located on south-facing slopes. 


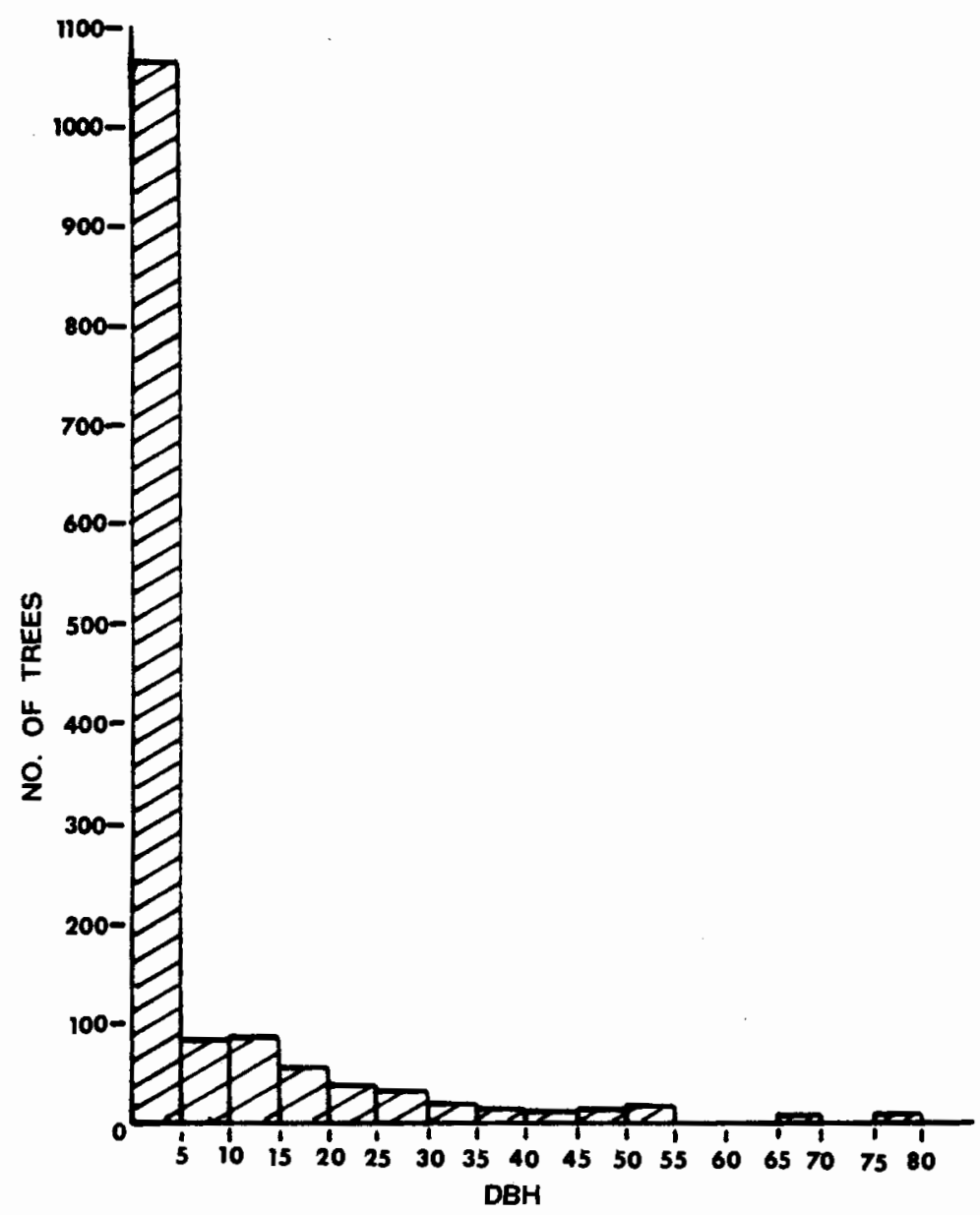

Figure 28. Summed $Q$. garryana population size-structure results for sites 1-15. 
Finally, oak was found to occupy a separate geographic area between the colliding Douglas fir/Ponderosa pine and western juniper/sagebrush/ grassland associations. While this ecological zone is made narrow by the rapidly changing environmental conditions resulting from the ascending Cascades, it appears nonetheless distinct. This situation, in addition to oak's relatively stable population structure (Figure 28), qualifies $Q$. garryana as a climatic climax species within its central Oregon range.

In order to more fully understand Oregon white oak's ecological situation, its distribution and size-structure results will be compared to climatic data in the following chapter. In addition, oak's response to climatic change, as well as the effects of differing slope aspect, will be discussed. 


\section{CHAPTER VI}

\section{THE EFFECTS OF CLIMATE ON OREGON WHITE OAK}

\section{INTRODUCTION}

While climate is recognized as the most important factor in plant maintenance and reproduction, separating its effects from those of other variables is a difficult task. Ideally, both experimental and comparative data are used. In the case of long-1ived species of little economic value, such as $\underline{Q}$. garryana, only the latter types of interpretation are available.

In the following evaluation, Oregon white oak's distribution is superimposed on average frost-free days and isohyet maps in order to reveal climatic limiting factors. Aberrations in the population sizestructure are dated using a tree age versus diameter correlation and compared to temperature and precipitation changes for possible causes and effects. And the response to climatic change by oak populations inhabiting north and south-facing slopes are contrasted.

\section{GENERAL CLTMATIC CONSIDERATIONS}

The dominant factor defining the rapid vegetation change from the Columbia River Gorge into central Oregon is increasing aridity. As shown in Figures 29-32, the precipitation changes in both quantity and seasonality. The mean annual precipitation drops from $750 \mathrm{~mm}$ at Hood River to $350 \mathrm{~mm}$ at The Dalles in a short $35 \mathrm{~km}$. And while Hood River receives over $85 \%$ of its precipitaton in the dormant months between October and March, Madras, which is $100 \mathrm{~km}$ to the southeast, receives 
only $60 \%$ of its molsture during this same period.

The distribution of Oregon white oak is noted to fall between the 625 and $1000 \mathrm{~mm}$ mean annual isohyet (U.S.D.A., 1965). Figure 33, however, shows that oak occurs well outside of these limits, from 300$1500 \mathrm{~mm}$ of precipitation. While the comparison of these data is useful in determining oak's precipiation requirements, favorable microhabitats, such as provided by drainage water-tables (see Figure 2), natural springs (Oakbrook Canyon and Oak Springs), rocky soils (Mosier Creek), and favorable slope aspects (White River Canyon) contribute to spreading oak out beyond its precipitation limits.

Many plant species are limited by the length of the frost-free season, through flower, fruit, and seedling damage. In order to test this hypothesis on $\underline{Q}$. garryana, its distribution is plotted on a map of the annual frost-free season for the study area (Figure 34). Oak is seen to occur in areas varying from over 200 to less than 80 frost-free days. While it is tempting to pin oak's southerly range cessation on this factor, such a conclusion seems overly-ambitious without better knowledge of the exact mechanisms involved.

\section{TEMPERATURE AND PRECIPITATION FLUCTUATIONS}

Climatic data were evaluated for 4 towns within the study area: Hood River, The Dalles, Dufur and Madras (Tables IV-VII).

Running means, as represented in Figures 35-40, were calculated in the following manner: a grand mean for the data was computed for the entire time interval, e.g. 1911-1975; this figure was subtracted from each individual datum; these results were added in 5-year intervals: and this figure was divided by 5 (e.g. $\left.\frac{(10-10)+(11-10)+(9-10)+\ldots . .}{5}\right)$. 

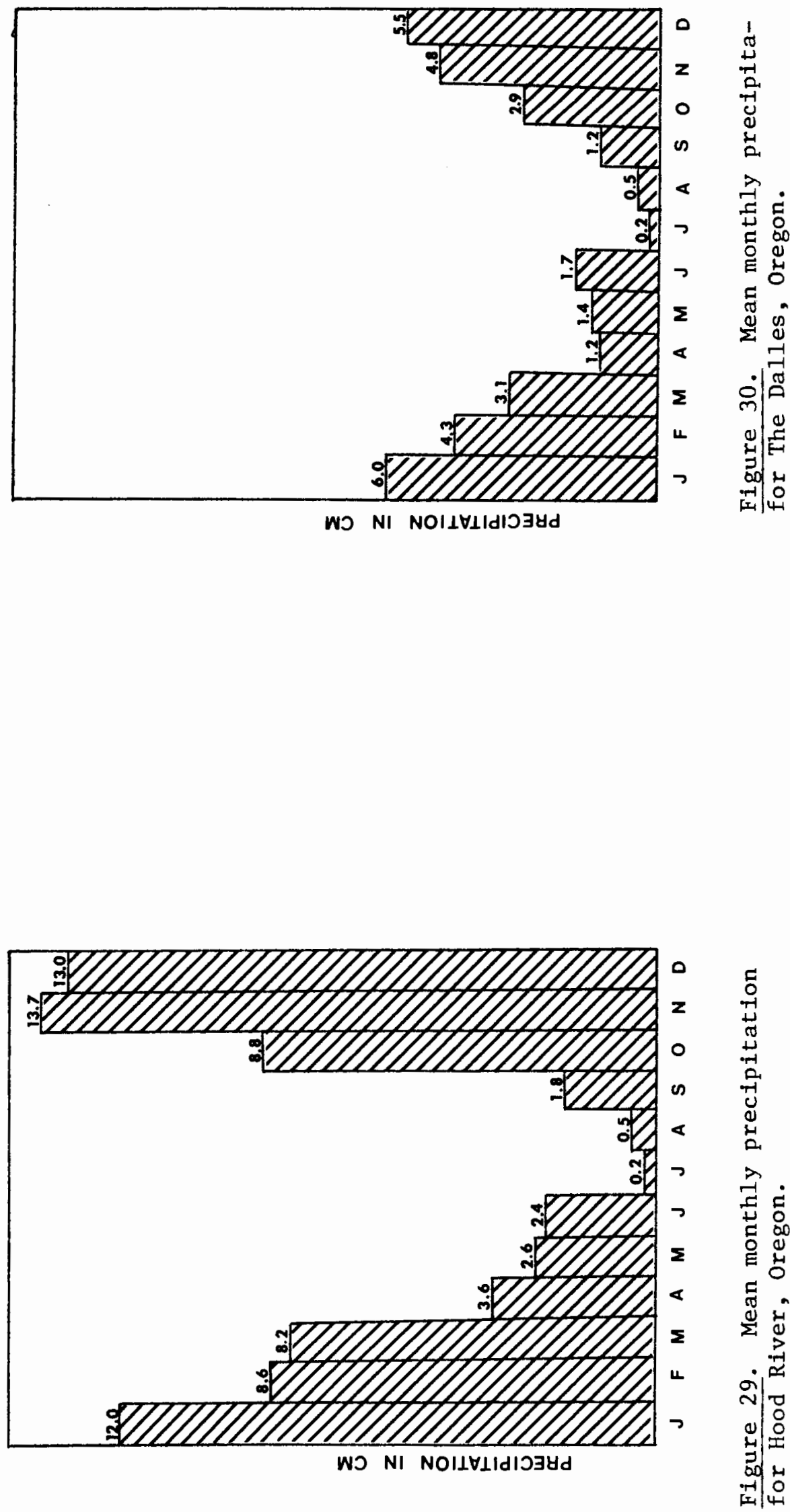


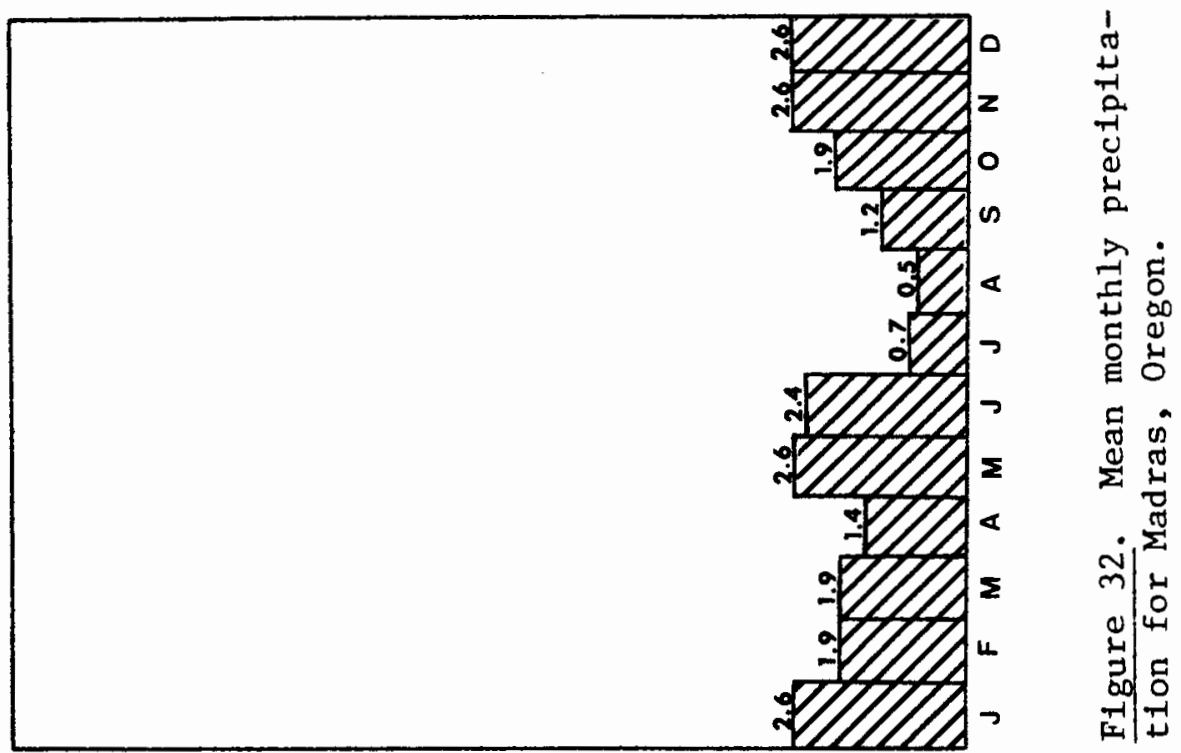

wO NI NOILIIdIOJyd

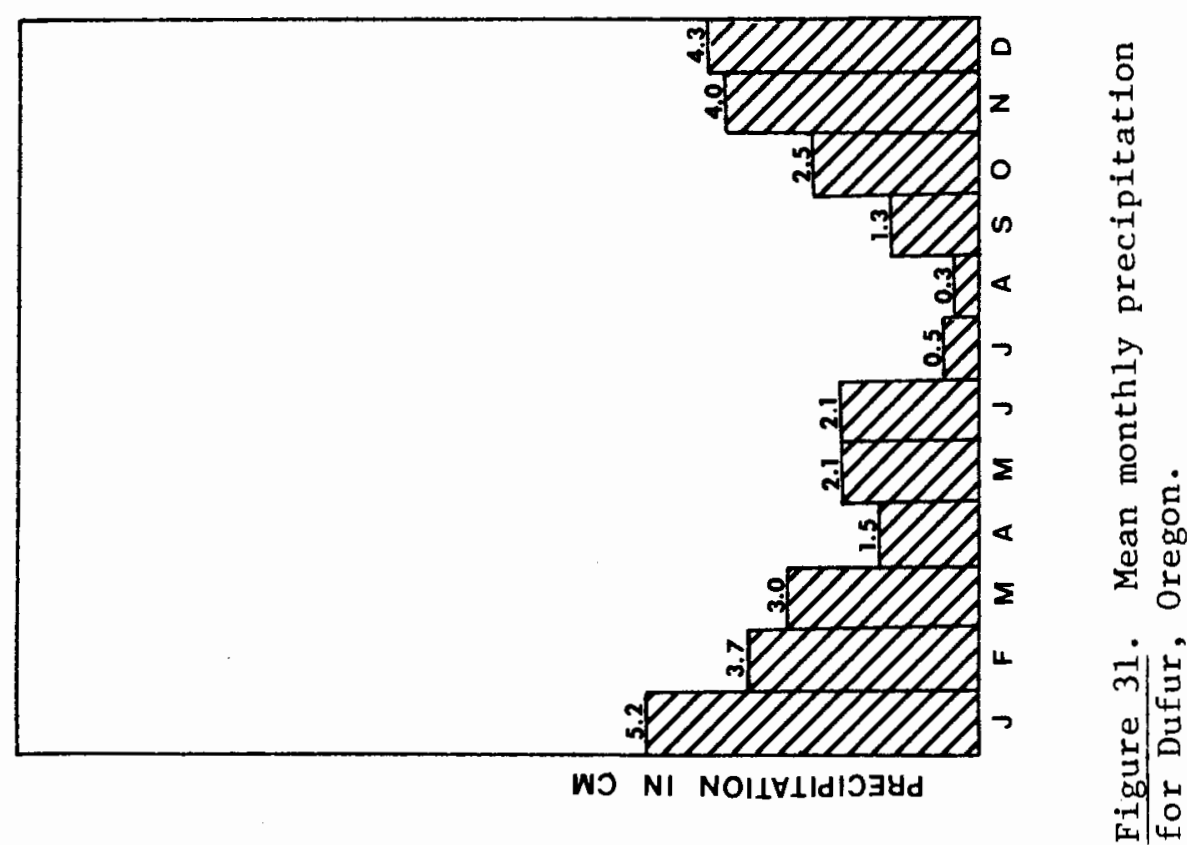




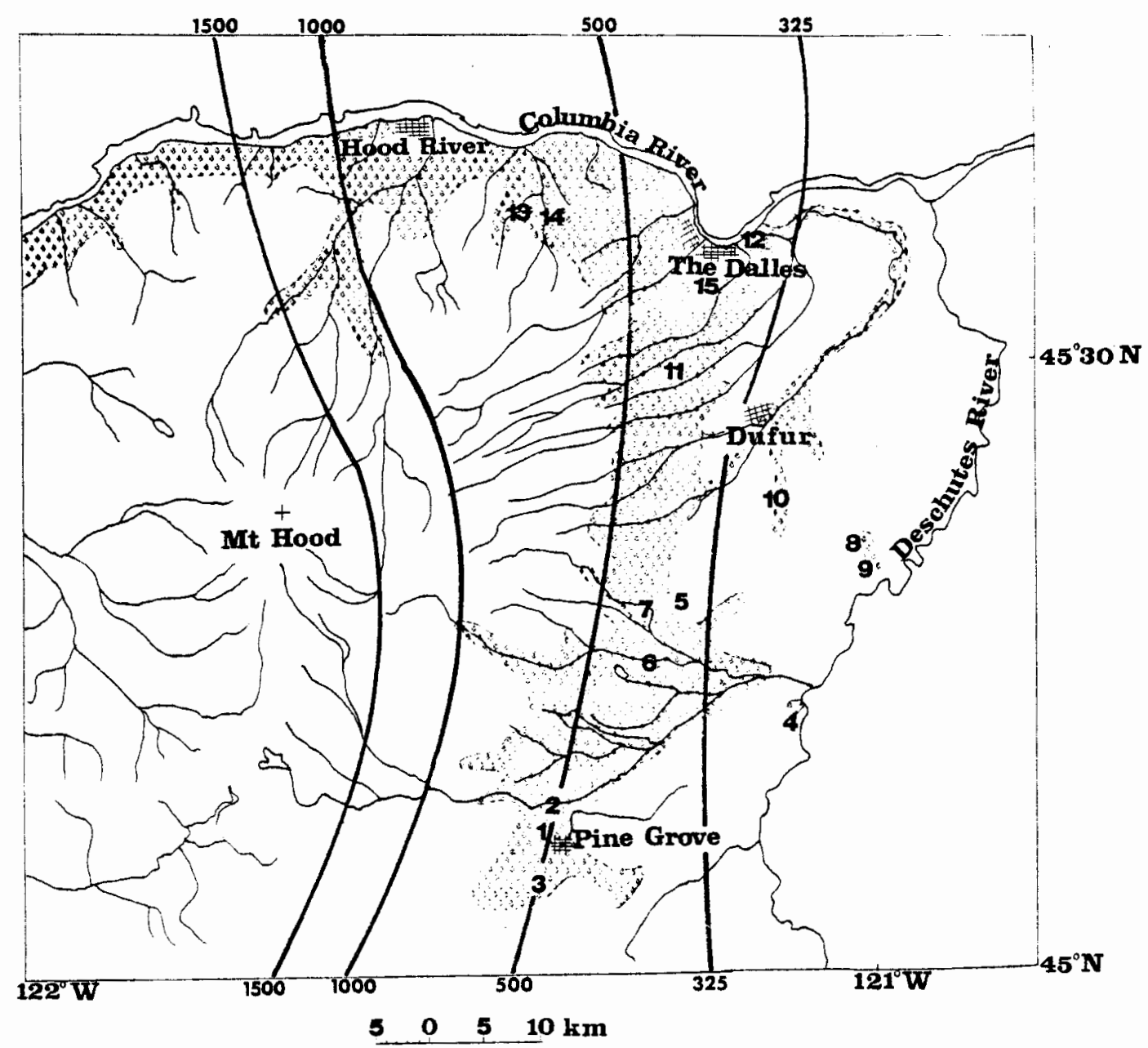

Figure 33. North-central Oregon's mean annual precipitation (cm) is superimposed on a map of Oregon white oak's distribution (precipitation data from Tables IV-VII. 


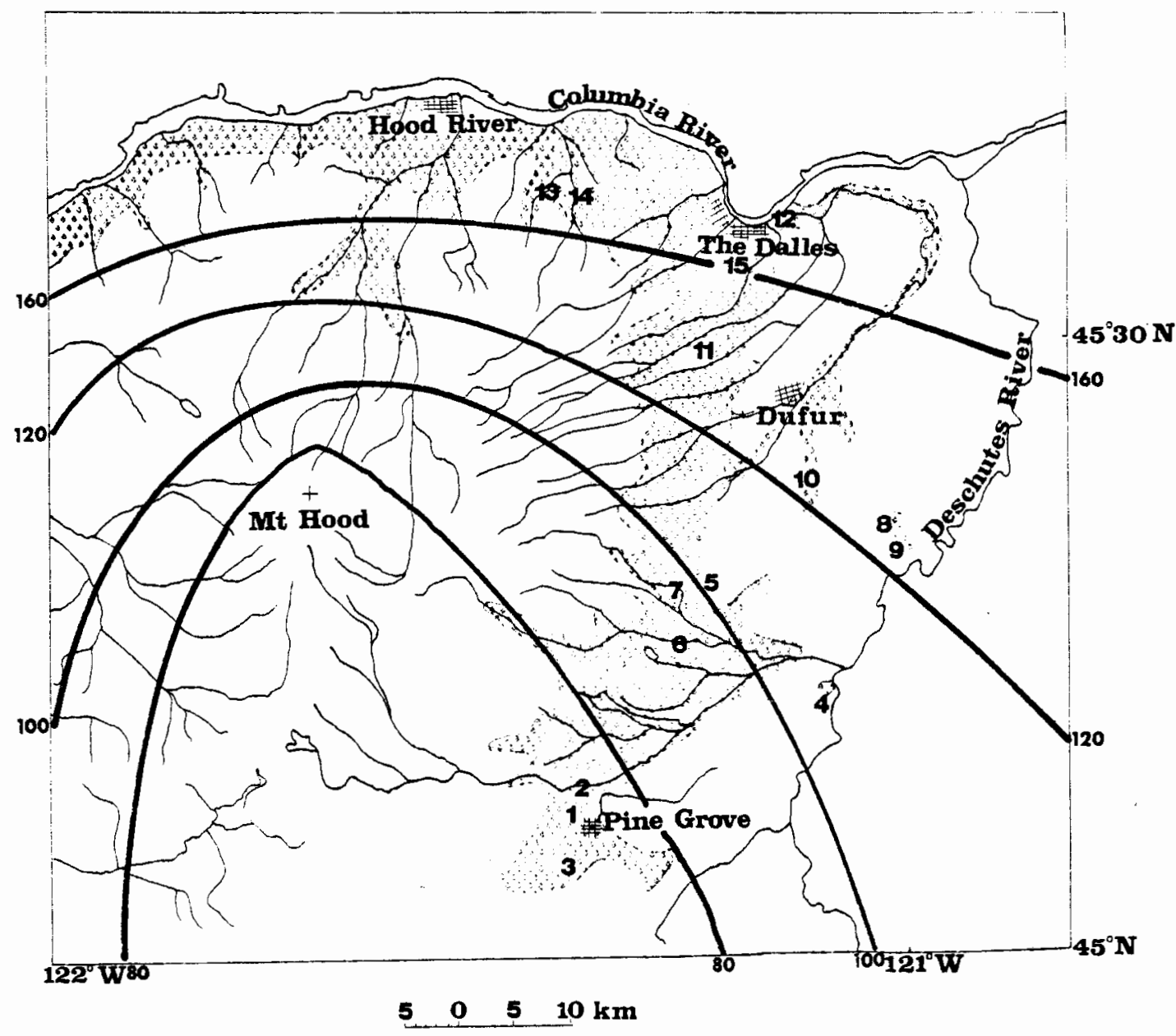

Figure 34. Average number of frost-free days per year is superimposed on a map of Oregon white oak's distribution (from Highsmith, 1968). 
TABLE IV

MEAN TEMPERATURE AND PRECIPITATION DATA: HOOD RIVER

\begin{tabular}{|c|c|c|c|c|c|c|}
\hline Year & $\begin{array}{l}\text { Mean Annual } \\
\text { Precip. (in) }\end{array}$ & $\begin{array}{l}\text { Mean Annual } \\
\text { Temp. }\left({ }^{\circ} F\right) \\
\end{array}$ & $\begin{array}{l}\text { Mean Temp. } \\
\text { Apr }{ }^{\circ}-\text { May } \\
\left({ }^{F}\right) \\
\end{array}$ & $\begin{array}{l}\text { Mean Temp. } \\
\text { Oct } \text {-Nov. }^{- \text {ov }} \\
\left({ }^{\mathrm{F}}\right) \\
\end{array}$ & $\begin{array}{l}\text { Mean } \\
\text { Precip. } \\
\text { Apr.- } \\
\text { May(in) }\end{array}$ & $\begin{array}{l}\text { Mean } \\
\text { Precip. } \\
\text { Oct.-Nov. } \\
\text { (in) }\end{array}$ \\
\hline 1911 & 18.6 & 50 & 47 & 45 & 2.7 & 2.3 \\
\hline 1913 & 22.5 & 50 & 53 & 52 & 2.4 & 8.3 \\
\hline 1915 & 30.2 & 52 & 54 & 48 & 3.6 & 11.2 \\
\hline 1917 & 32.2 & 50 & 49 & 48 & 4.0 & 4.3 \\
\hline 1919 & 35.2 & 48 & 53 & 44 & 3.1 & 8.4 \\
\hline 1921 & 37.9 & 50 & 53 & 46 & 1.9 & 15.3 \\
\hline 1923 & ---- & 51 & 52 & 48 & --- & 3.5 \\
\hline 1925 & 24.2 & 52 & 55 & 45 & 3.7 & 4.4 \\
\hline 1927 & 30.2 & 51 & 52 & 49 & 1.9 & 8.8 \\
\hline 1929 & 19.0 & 49 & 52 & 47 & 2.3 & .3 \\
\hline 1931 & 29 & 50 & 56 & 45 & 1.6 & 7.4 \\
\hline 1933 & 35.7 & 50 & 51 & 49 & 1.5 & 5.0 \\
\hline 1935 & 16.6 & 49 & 51 & 43 & 1.8 & 2.5 \\
\hline 1937 & 37.0 & 50 & 52 & 50 & 4.3 & 8.7 \\
\hline 1939 & 18.5 & 52 & 54 & 48 & 1.2 & 1.3 \\
\hline 1941 & 24.8 & 52 & 55 & 47 & 3.0 & 5.9 \\
\hline 1943 & 27.1 & 49 & 53 & 46 & 2.9 & 8.8 \\
\hline 1945 & 32.1 & 50 & 53 & 46 & 4.5 & 9.3 \\
\hline 1947 & 29.6 & 52 & 57 & 48 & 1.7 & 10.3 \\
\hline 1949 & 28.5 & 50 & 55 & 47 & 5.6 & 12.7 \\
\hline 1951 & 34.5 & 50 & 54 & 40 & 1.7 & 10.5 \\
\hline 1953 & 34.6 & 52 & 51 & 49 & 5.6 & 6.1 \\
\hline 1955 & 34.7 & 49 & 49 & 42 & 3.8 & 12.4 \\
\hline 1957 & 31.6 & 50 & 55 & 46 & 2.3 & 5.3 \\
\hline 1959 & 24.0 & 51 & 52 & 46 & 1.9 & 5.3 \\
\hline 1961 & 38.0 & 51 & 52 & 44 & 2.9 & 7.0 \\
\hline 1963 & 26.0 & 50 & 51 & 48 & 3.6 & 7.8 \\
\hline 1965 & 24.2 & 51 & 52 & 49 & 3.0 & 6.4 \\
\hline 1967 & 24.3 & 53 & 51 & 48 & 1.5 & 8.0 \\
\hline 1969 & 26.5 & 50 & 54 & 46 & 2.1 & 3.4 \\
\hline 1971 & 32.6 & 50 & 52 & 45 & 2.2 & 6.9 \\
\hline 1973 & 35.0 & 51 & 54 & 45 & 1.2 & 13.7 \\
\hline 1975 & 36.6 & -- & 49 & 46 & .9 & 10.3 \\
\hline mean & 29.1 & 50.5 & 52.5 & 46.7 & 2.6 & 7.3 \\
\hline
\end{tabular}


TABLE V

MEAN TEMPERATURE AND PRECIPITATION DATA: THE DALLES

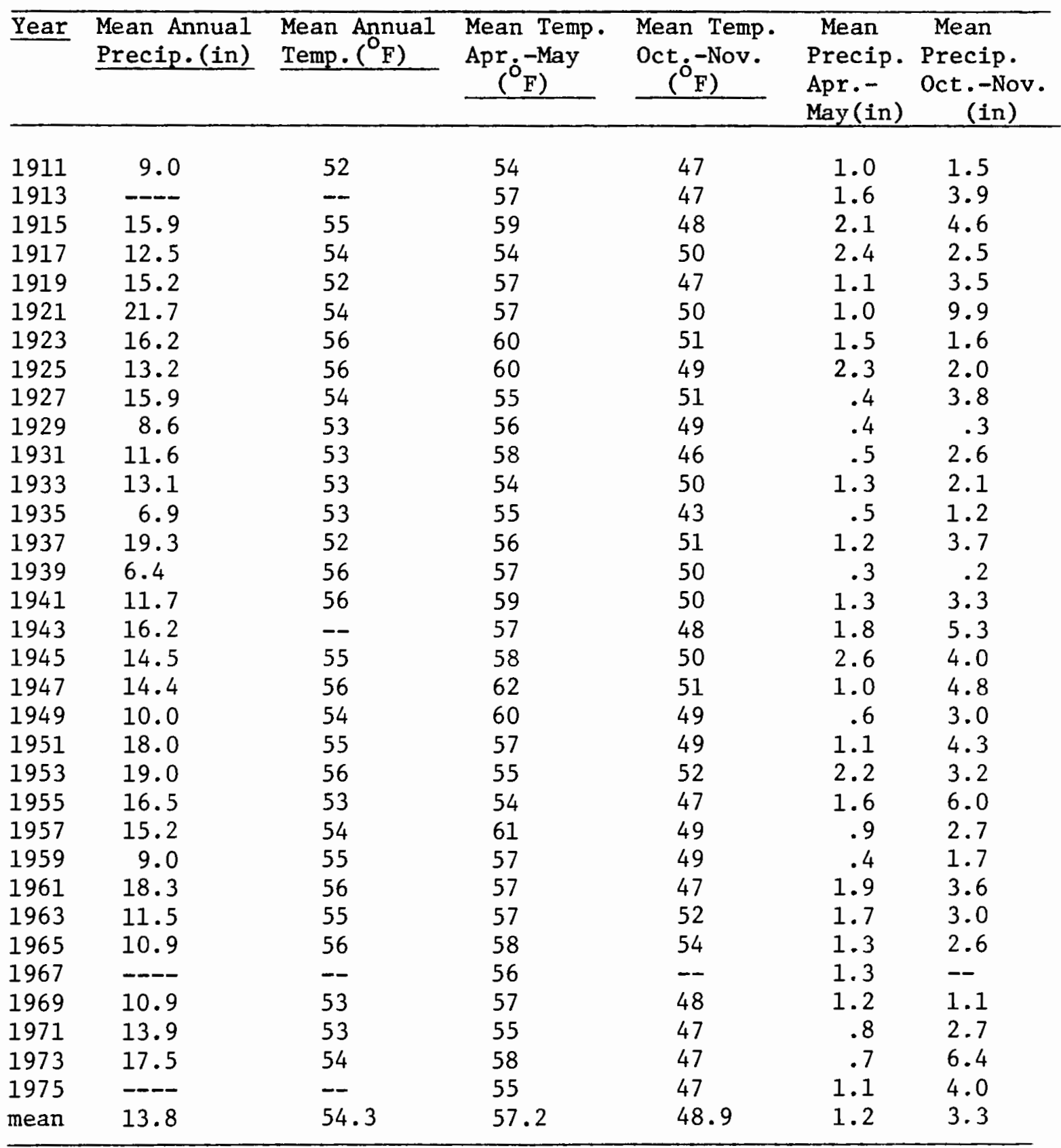


TABLE VI

MEAN TEMPERATURE AND PRECIPITATION DATA: DUFUR

\begin{tabular}{|c|c|c|c|c|c|c|}
\hline Year & $\begin{array}{l}\text { Mean Annual } \\
\text { Precip. (in) }\end{array}$ & $\begin{array}{l}\text { Mean Annual } \\
\text { Temp. ( } \mathrm{F} \text { ) } \\
\end{array}$ & $\begin{array}{l}\text { Mean Temp. } \\
\text { Apr } \dot{\mathrm{d}}^{- \text {May }} \\
\left({ }^{\mathrm{F}}\right) \\
\end{array}$ & $\begin{array}{l}\text { Mean Temp. } \\
\text { Oct. }- \text { Nov. } \\
\left({ }^{\mathrm{o}}\right)\end{array}$ & $\begin{array}{l}\text { Mean } \\
\text { Precip. } \\
\text { Apr.-- } \\
\text { May (in) }\end{array}$ & $\begin{array}{l}\text { Mean } \\
\text { Precip. } \\
\text { Oct.-Nov. } \\
\text { (in) }\end{array}$ \\
\hline 1919 & 17.4 & 46 & 49 & 42 & 1.2 & 2.7 \\
\hline 1921 & 17.5 & 47 & 48 & 45 & 1.4 & $7 / 3$ \\
\hline 1923 & 14.9 & 47 & 49 & 45 & 1.6 & 1.8 \\
\hline 1925 & 10.7 & 49 & 51 & 43 & 3.1 & 2.0 \\
\hline 1927 & 14.7 & 47 & 47 & 46 & .3 & 3.7 \\
\hline 1929 & 7.8 & 48 & 50 & 46 & .7 & .2 \\
\hline 1931 & 10.3 & 50 & 55 & 43 & .4 & 1.2 \\
\hline 1933 & 9.6 & 49 & 49 & 48 & 1.2 & 1.3 \\
\hline 1935 & 5.1 & 49 & 51 & 42 & .5 & 1.0 \\
\hline 1937 & 15.5 & 49 & 50 & 48 & 1.5 & 3.6 \\
\hline 1939 & 6.2 & 55 & 54 & 47 & .3 & .2 \\
\hline 1941 & 11.2 & 51 & 54 & 46 & 1.6 & 3.5 \\
\hline 1943 & 12.5 & 49 & 52 & 46 & 1.6 & 2.0 \\
\hline 1945 & - - & - & 52 & 48 & 3.0 & 2.8 \\
\hline 1947 & 13.0 & 51 & 57 & 47 & 1.1 & 5.5 \\
\hline 1949 & 8.2 & 49 & 57 & 46 & .6 & 2.3 \\
\hline 1951 & 14.0 & 50 & 53 & 44 & 1.6 & 3.1 \\
\hline 1953 & 14.7 & 51 & 50 & 48 & 2.5 & 2.5 \\
\hline 1955 & 13.6 & 48 & 49 & 42 & 2.1 & 4.0 \\
\hline 1957 & 13.4 & 49 & 55 & 40 & 1.8 & 2.1 \\
\hline 1959 & 8.9 & 50 & 51 & 45 & .7 & 1.1 \\
\hline 1961 & 14.7 & 52 & 52 & 43 & 2.1 & 2.2 \\
\hline 1963 & 12.2 & -- & 51 & 45 & 2.1 & 2.2 \\
\hline 1965 & 10.2 & 50.0 & 51 & 48 & 1.5 & 2.8 \\
\hline 1967 & 7.1 & 51 & 49 & 46 & 1.7 & 2.4 \\
\hline 1969 & 10.9 & 48 & 53 & 44 & 2.4 & 1.2 \\
\hline 1971 & 10.9 & 48 & 50 & 42 & 1.6 & 1.9 \\
\hline 1973 & 13.7 & 49 & 52 & 44 & .6 & 6.0 \\
\hline 1975 & 13.7 & 48 & 47 & 44 & 1.2 & 2.7 \\
\hline mean & 11.9 & 49.0 & 51.3 & 44.9 & 1.4 & 2.6 \\
\hline
\end{tabular}


TABLE VII

MEAN TEMPERATURE AND PRECIPITATION DATA: MADRAS

\begin{tabular}{|c|c|c|c|c|c|c|}
\hline Year & $\begin{array}{l}\text { Mean Annual } \\
\text { Precip. (in) }\end{array}$ & $\begin{array}{l}\text { Mean Annual } \\
\text { Temp. }(\mathrm{F})\end{array}$ & $\begin{array}{l}\text { Mean Temp. } \\
\text { Apr } \dot{o}^{-M a y} \\
\left({ }_{F}\right)\end{array}$ & $\begin{array}{c}\text { Mean Temp. } \\
\text { Oct. }- \text { Nov. } \\
\left({ }^{\mathrm{O}} \mathrm{F}\right)\end{array}$ & $\begin{array}{l}\text { Mean } \\
\text { Precip. } \\
\text { Apr.- } \\
\text { May (in) }\end{array}$ & $\begin{array}{c}\text { Mean } \\
\text { Precip. } \\
\text { Oct.-Nov. } \\
\text { (in) }\end{array}$ \\
\hline 1921 & 10.1 & 48 & 48 & 45 & 2.3 & 3.1 \\
\hline 1923 & 9.5 & 48 & 49 & 44 & 2.1 & 1.7 \\
\hline 1925 & 8.9 & 49 & 52 & 42 & 4.0 & 1.2 \\
\hline 1927 & 10.8 & 47 & 47 & 46 & .4 & 1.6 \\
\hline 1929 & 7.9 & 45 & 48 & 41 & 1.9 & 1.1 \\
\hline 1931 & 7.0 & 48 & 52 & 39 & .7 & 1.1 \\
\hline 1933 & 5.4 & 48 & 47 & 44 & 1.8 & .7 \\
\hline 1935 & 6.6 & 46 & 47 & 39 & 1.4 & 1.1 \\
\hline 1937 & 14.5 & 47 & 54 & 46 & 1.8 & 4.0 \\
\hline 1939 & 5.0 & 49 & 51 & 43 & .4 & .4 \\
\hline 1941 & 12.2 & 48 & 49 & 44 & 2.0 & 2.9 \\
\hline 1943 & 8.8 & 46 & 47 & 43 & 1.8 & 2.3 \\
\hline 1945 & 10.9 & 48 & 49 & 44 & 3.2 & 2.5 \\
\hline 1947 & 10.5 & 49 & 53 & 46 & .9 & 3.3 \\
\hline 1949 & 4.1 & 47 & 52 & 41 & .5 & 2.1 \\
\hline 1951 & 9.7 & 47 & 49 & 42 & 1.6 & 2.6 \\
\hline 1953 & 12.2 & 49 & 47 & 46 & 1.7 & 2.5 \\
\hline 1955 & 9.8 & 46 & 45 & 42 & 1.7 & 2.4 \\
\hline 1957 & 12.8 & 46 & 51 & 40 & 3.7 & 1.1 \\
\hline 1959 & -- & -- & 47 & -- & 1.2 & -- \\
\hline 1961 & 12.9 & 50 & 49 & 41 & 1.7 & 3.5 \\
\hline 1963 & 11.3 & 48 & 49 & 46 & 2.7 & 2.4 \\
\hline 1965 & 9.6 & 49 & 50 & 47 & 1.4 & 2.6 \\
\hline 1967 & 5.9 & -- & 48 & 45 & 1.8 & 1.0 \\
\hline 1969 & 13.6 & -- & -- & 44 & 1.4 & 1.2 \\
\hline 1971 & 9.0 & 49 & 50 & 44 & 1.7 & 1.6 \\
\hline 1973 & 11.0 & -- & 50 & 44 & .7 & 4.2 \\
\hline 1975 & 10.7 & -- & -- & 45 & 1.1 & 1.7 \\
\hline mean & 9.7 & 47.7 & 49.2 & 43.4 & 1.7 & 2.1 \\
\hline
\end{tabular}


These computations are graphed as variations about the mean (0) line for ease of comparison between stations.

Six types of data were compiled in Tables IV-VII: mean annual precipitation and temperature; mean temperature and precipitation for October and November; and mean temperature and precipitation for April and May. The 2-month interval results represent the period of most effective precipitation for $Q$. garryana. In the fall, oak germinates and quickly takes root if soil conditions are favorable; temperature and precipitation extremes during this period should be critical factors in survival of seedlings. The timing of spring rainfall and temperature increases are important to the survival of the previous year's seedlings.

The climatic trends exhibited in Figures $35-40$ are discussed and compared to the size-structure data. A point worth noting is that a well-documented arid cycle, known variously as the "dust bowl years" or simply the "1930s drought", occurred on a global scale. Climatic records (Page, 1937) and tree ring data (Fritts, 1966) indicate that extremely dry conditions prevailed throughout the western United States from the late 1920 s to the late 1930s. On a local level, Keen's (1937) tree ring evaluation revealed that the drought of 1917-1935 was the most severe that central Oregon had perserved for the last 650 years. Thus, if oak's regeneration is sensitive to climatic change, this period should serve as a good index of response.

In general, the precipitation graphs elicit a more cyclical sequence of above and below-normal figures than the temperature data, which seems more randomly distributed. The correlation between annual and fall precipitation is particularly close. The 1930 s drought stands out, spanning the late 1920 s into the late 1930s. The temperature variations, 


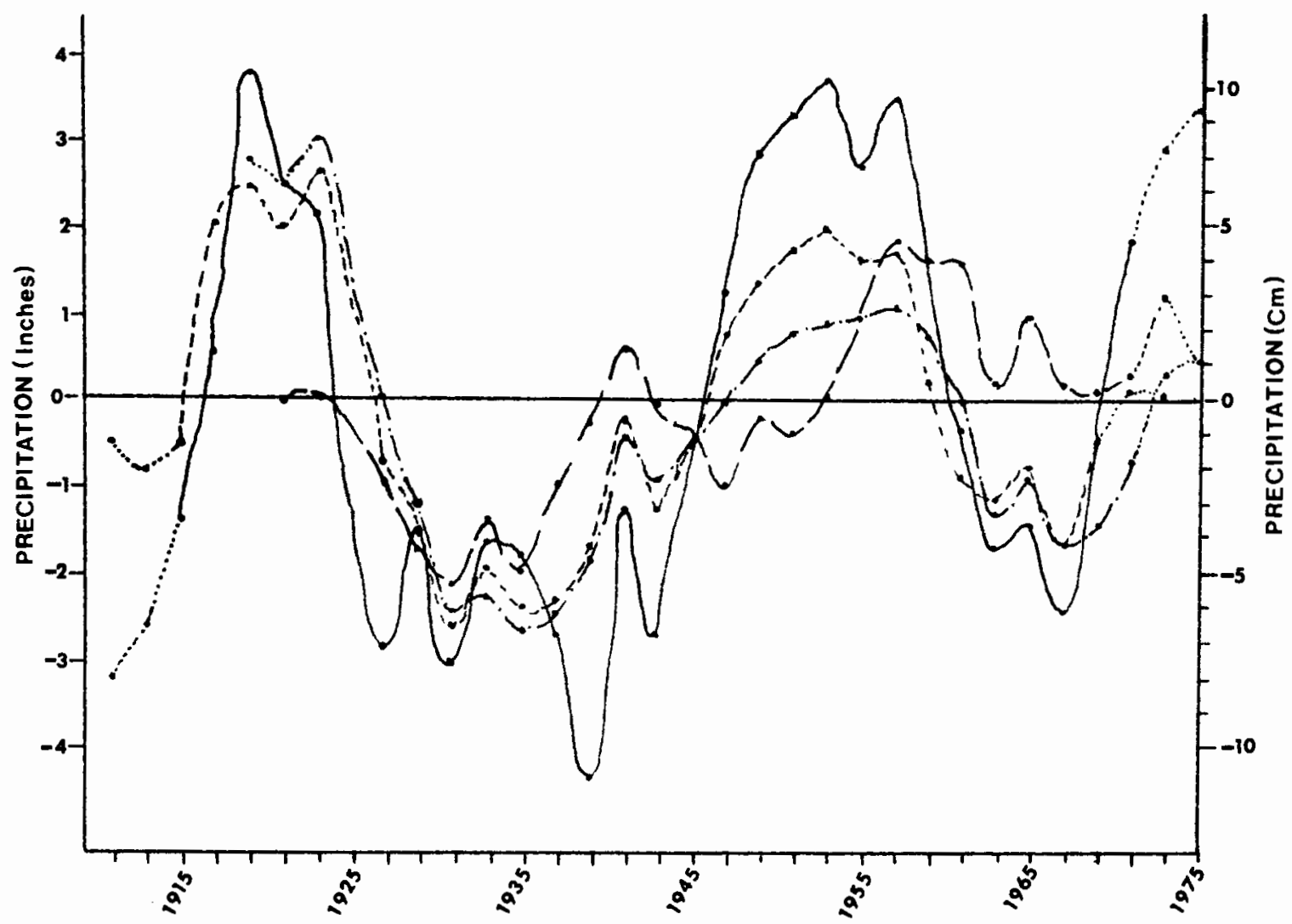

Figure 35. Annual precipitation running-mean variations from the grand mean for climatological

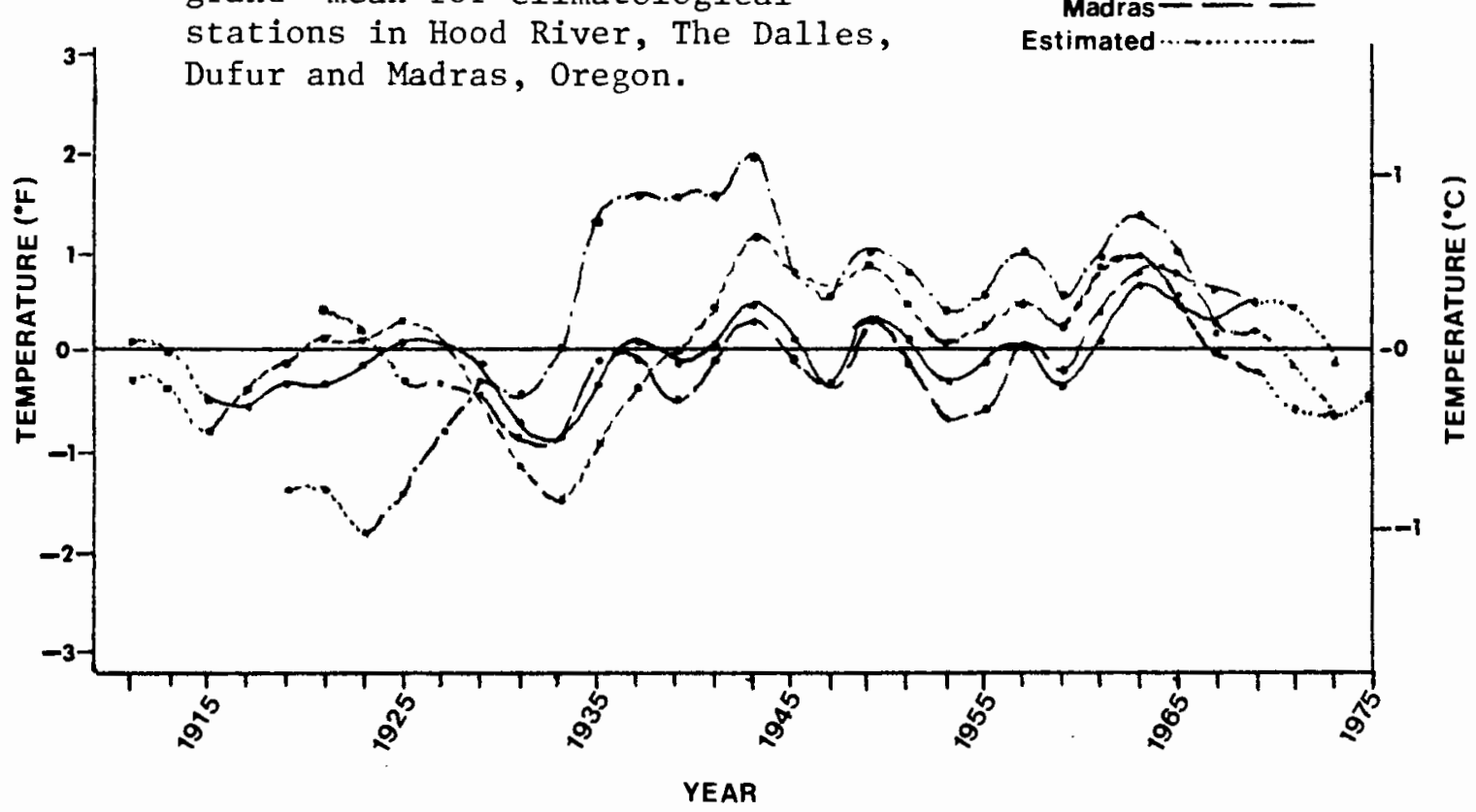

Figure 36. Annual temperature running-mean variations from the grand mean for climatological stations in Hood River, The Dalles, Dufur and Madras, Oregon. 


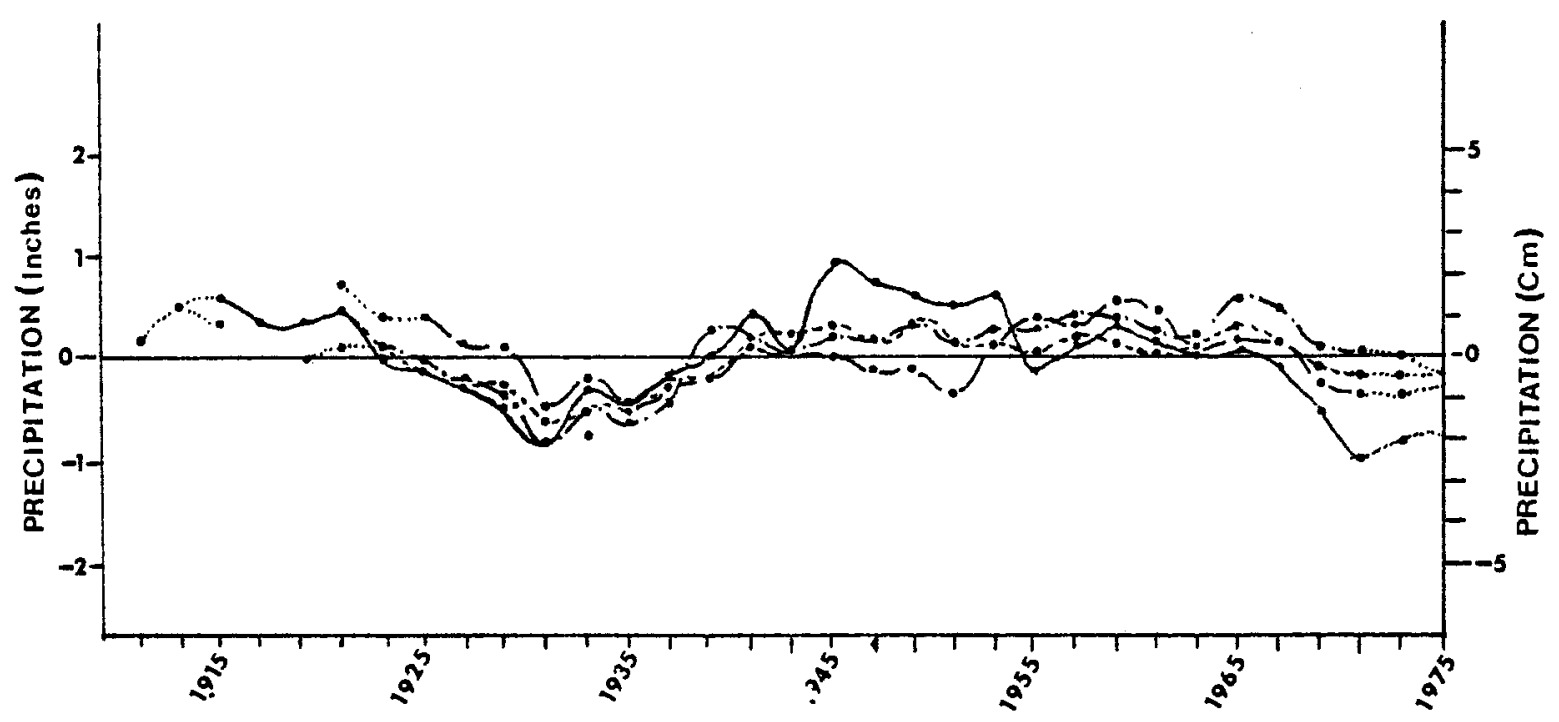

Figure 37. Spring (Apri1-May) precipitation running-mean variations from the grand mean for climatological stations in Hood River, The Dalles, Dufur and Madras, Oregon.

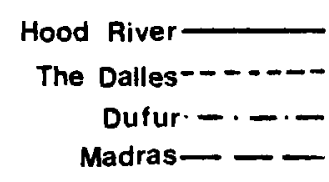

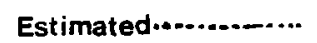

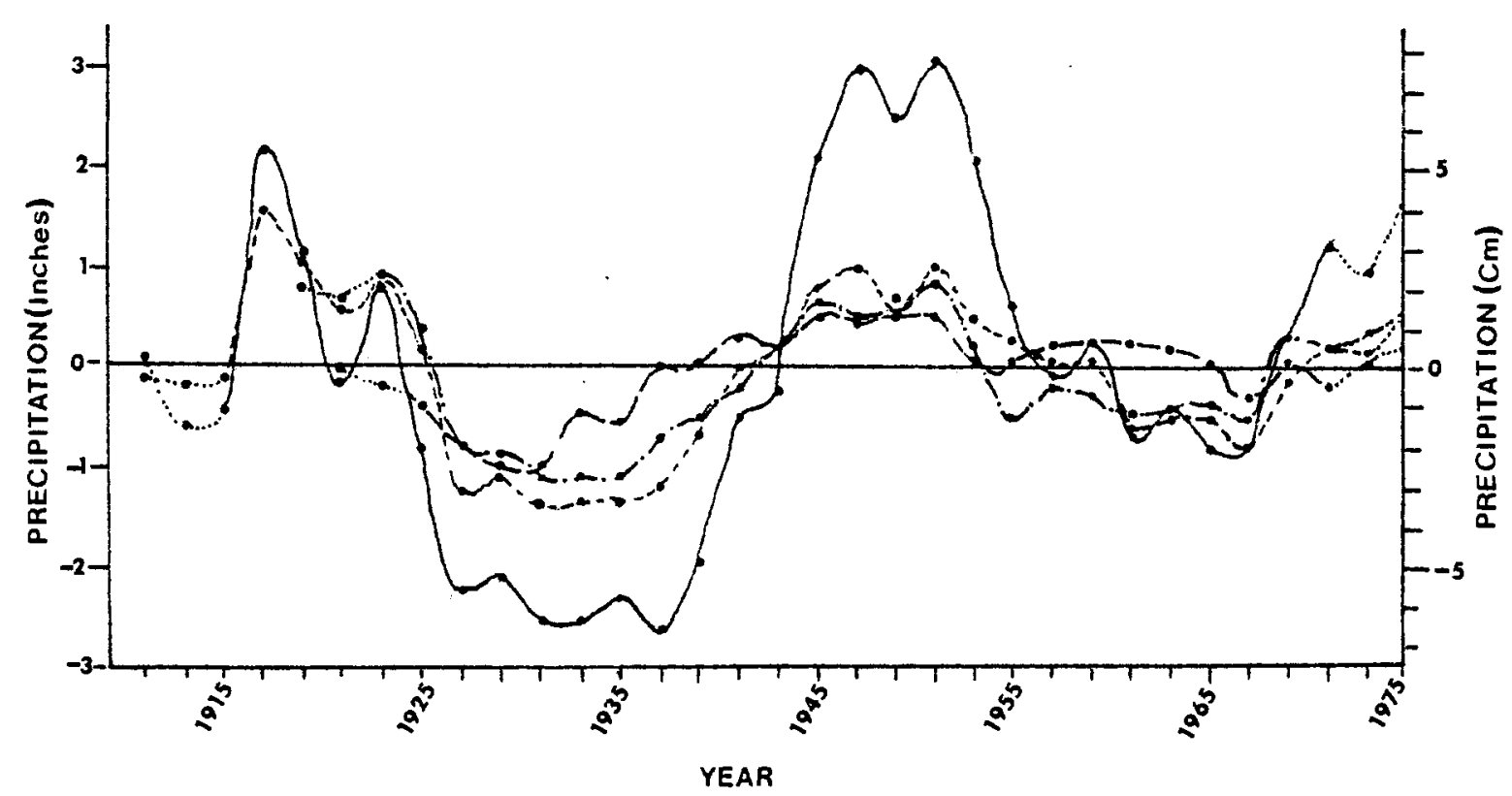

Figure 38. Autumn (October-November) precipitation running-mean variations from the grand mean for climatological stations in Hood River, The Dalles, Dufur, and Madras, Oregon. 


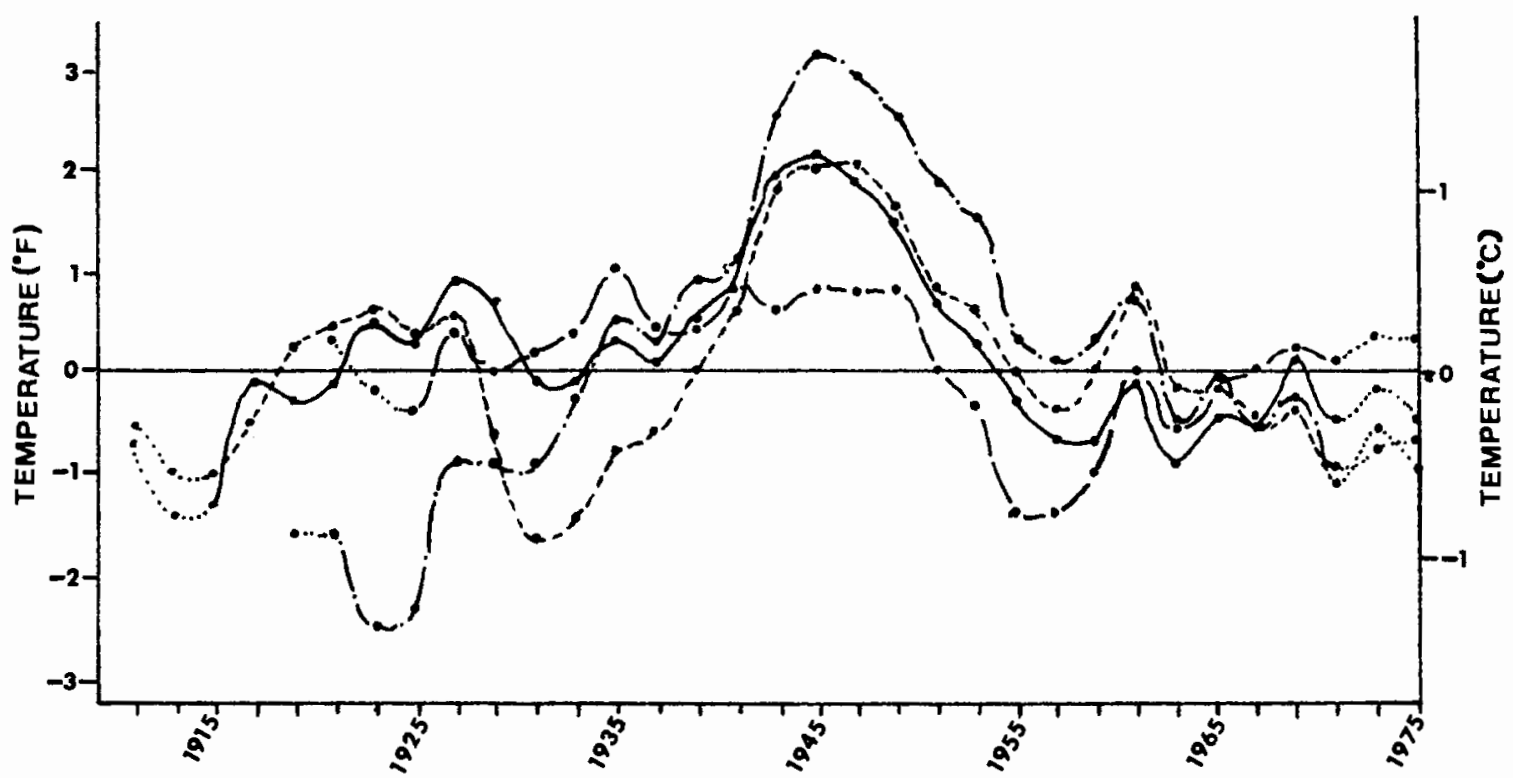

Figure 39. Spring (Apri1-May) temperature running-mean variations from the grand mean for climatological stations in Hood River, The Dalles, Dufur, and Madras, Oregon.
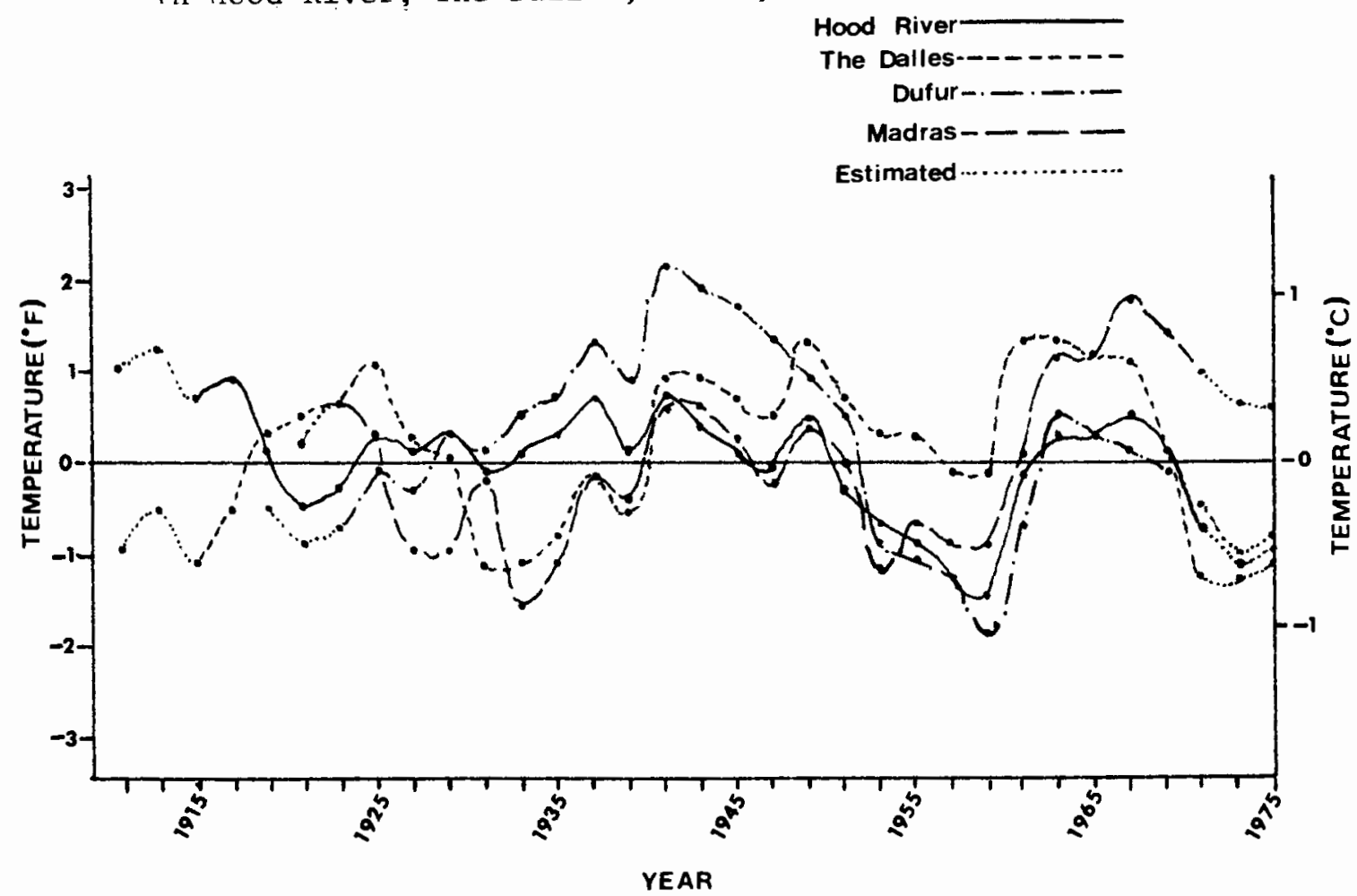

Figure 40. Autumn (October-November) temperature running-mean variations from the grand mean for climatological stations in Hood River, The Dalles, Dufur and Madras, Oregon. 
however, show little seasonal or annual correlation.

COMPARISON OF OAK SIZE-STRUCTURES TO CLIMATIC CHANGE

Q. garryana size-structures, as shown in Figures 4-25, exhibit periods of relatively higher or lower reproduction. In order to link these variations to possible climatic causative factors, chronological values were assigned to the successive size-classes. A small group of oaks were cored, their diameters measured (Table VIII), and a linear correlation was established for these 2 variables (Figure 41). An evaluation of variation around the line-of-best-fit showed the linear function to be statistically significant (Appendix III, Table I). Using the estimation of $\mathrm{x}$-coordinates from $\mathrm{y}$-coordinates, ages were assigned to each potential oak size-class (Appendix III, Table II). The following is a discussion of dated size-class variations from the expected reverse $J$ curve reproductive curve in relation to the climatic fluctuations derived from Figures $35-40$. The sites are divided into two groups: those which show anticipated responses to climatic variations and those which do not. These divisions were based on $Q$. garryana's reproductive response to wetter or drier conditions considered in respect to the population's location at either the arid or moist frontier of its range. Oak stands which were inhabited by Douglas fir or ponderosa were considered to be at their upper moisture limits; those sharing their site with junipers, desert shrubs, and grasses were classified to be at their arid limits. Oak's response at its arid limits to the 1930 s drought should be reduced reproduction; at its upper precipitation limits, periods of drought should favor oak reproduc- 
TABLE VIII

OREGON WHITE OAK TREE RING DATA

Tree Number

1

2

3

4

5

6

7

8

9

10

11

12

13

14

15

\section{Diameter (cm)}

19.9

7.6

15.3

29.0

16.8

19.1

9.2

9.2

25.2

17.5

8.4

15.3

6.1

10.7

39.0
Age (Years)

56

28

56

49

48

52

36

41

63

36

35

53

33

32

84 


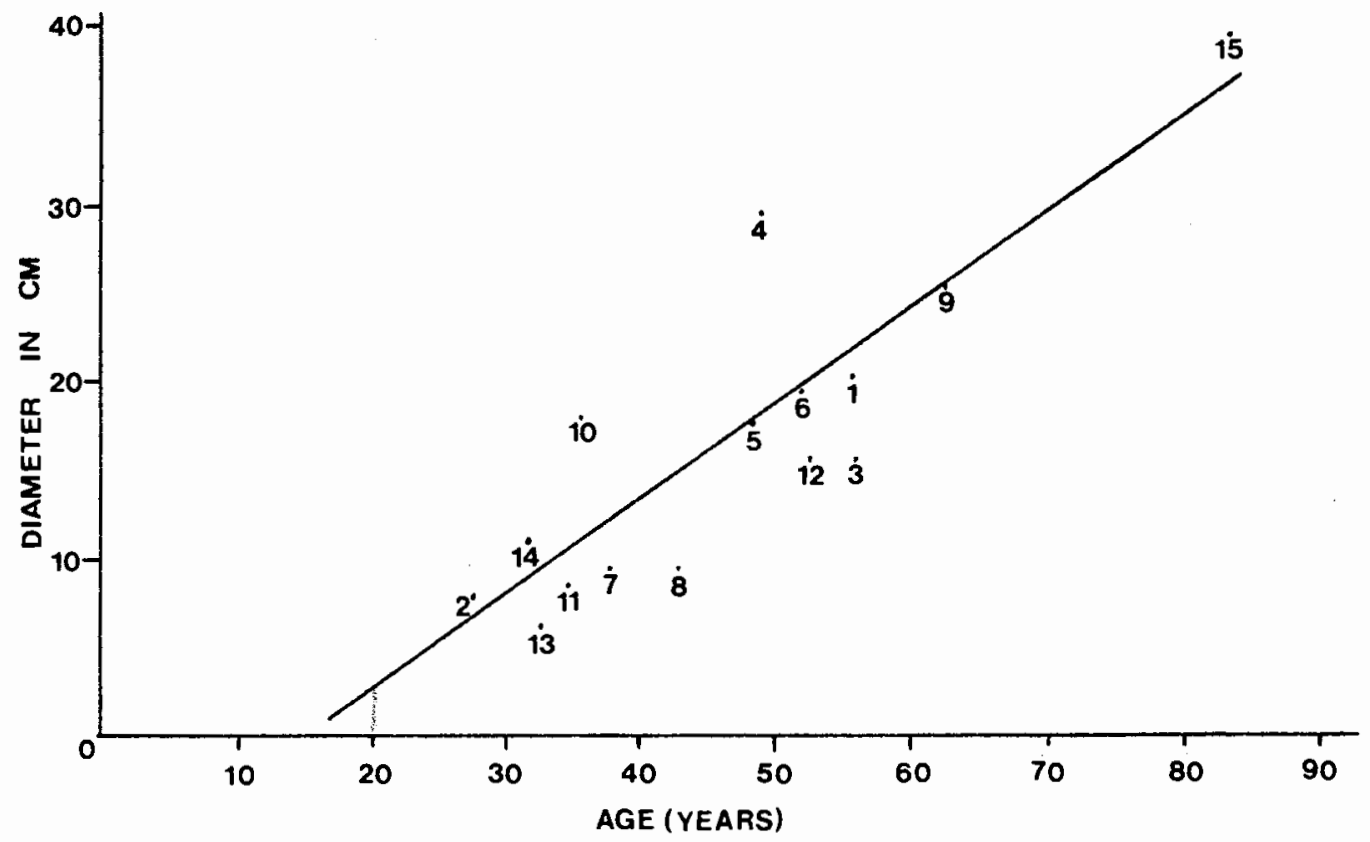

Figure 41. Age and diameter-at-breast-height for a stand of Oregon white oak trees. 
tion over Douglas fir or ponderosa pine. Moist periods should elicit opposite reproductive responses.

SITES WITH A POSITIVE SIZE-STRUCTURE VERSUS CLIMATIC CORRELATION

The population at site 2 (Figure 7) shows a rapid drop in numbers of individuals below $17 \mathrm{~cm} \mathrm{dbh}$, or near 1928* Regeneration resumed in the $5 \mathrm{~cm}$ dbh class, or since about 1951. This gap in reproduction between 1928 and 1950 correlates with the drought as depicted in Figures 35 and 38. The resumption of reproduction after 1951 may be a result of increased precipitation. Most of the young oaks, however, are of coppice origin, indicating that some other factor may have restrained oak regeneration after the drought.

The oaks at site 3 (Figure 9) exhibited excellent correlation to precipitation variations. The oldest individual - $14 \mathrm{~cm} \mathrm{dbh} \mathrm{-} \mathrm{sprouted}$ in approximately 1934 in the middle of the drought (Figures 35 and 38). Oak reproduced successfully after this time, while reproduction in Douglas fir and ponderosa pine was greatly reduced (Figures 10-11). These species were out-competed by Oregon white oak during this drought. Oak is normally only a subordinate member of plant communities at this elevation $(800 \mathrm{~m})$ due to overtopping by conifers. The drought, however, provided the drier conditions under which oak could temporarily stifle its mesic associates. The return of wetter conditions should have signaled the cessation of oak dominance, although the size-structure does not reveal this. Many oaks, however, we re visually noted to be

${ }^{*}$ The chronology of each size-class, as taken from Appendix III, is estimated by subtracting the age for the size-class from the study year, 1976. Thus $5 \mathrm{~cm}=25.0$ years; subtracting this figure from 1976 yields the date of oak germination: $1976-25.0=1951$. 
dead or dying due to overtopping by faster-growing ponderosa pines. In addition, many of the dying oaks were coppice sprouting, which accounts for the bulk of recent oak regeneration.

The oak size-structure at site 5 (Figure 13) conforms to the expected reverse $\mathrm{J}$ curve with the exception of the $6-10 \mathrm{~cm}$ dbh class. The cessation of regeneration occurs at $12 \mathrm{~cm}$, or near 1938, and correlates with the termination of drought conditions. The continued lack of regeneration after this period, however, is unaccounted for in the climatic data. The large number of sprouts is misleading in that over $90 \%$ were in tight clumps, probably of coppice origin (see Figure 42). Thus, while the drought seems to account for the initial reduction in regeneration, something else is causing the lack of recent reproduction.

The $Q$. garryana population at site 6 exhibits excellent correlation to the reverse J curve (Figure 14). Most of the oaks sprouted after 1932 (15 $\mathrm{cm} \mathrm{dbh)} \mathrm{during} \mathrm{the} \mathrm{1930s} \mathrm{drought.} \mathrm{Ponderosa} \mathrm{pine,} \mathrm{which}$ also inhabits this site, appears to be in the process of being replaced by oak; the complete lack of pine regeneration (Figure 15) coincides with the upsurge in oak reproduction. It is not immediately obvious, however, why pine is not currently replacing oak.

The oak size-structure for site 7 (Figure 16) fits the reverse $J$ curve with the exception of a reproductive gap during a moist period from 1902-1924 (19-30 cm dbh). Thus oak reproduction decreased during a period of abundant precipitation and increased during the drought. This probably resulted from competition with ponderosa pine during the moist period, followed by less competition during the dry spell (Figure 17). Such an interpretation is confused, however, by ponderosa pine's apparent release from fire pressure during the 1930 s drought (Weaver, 


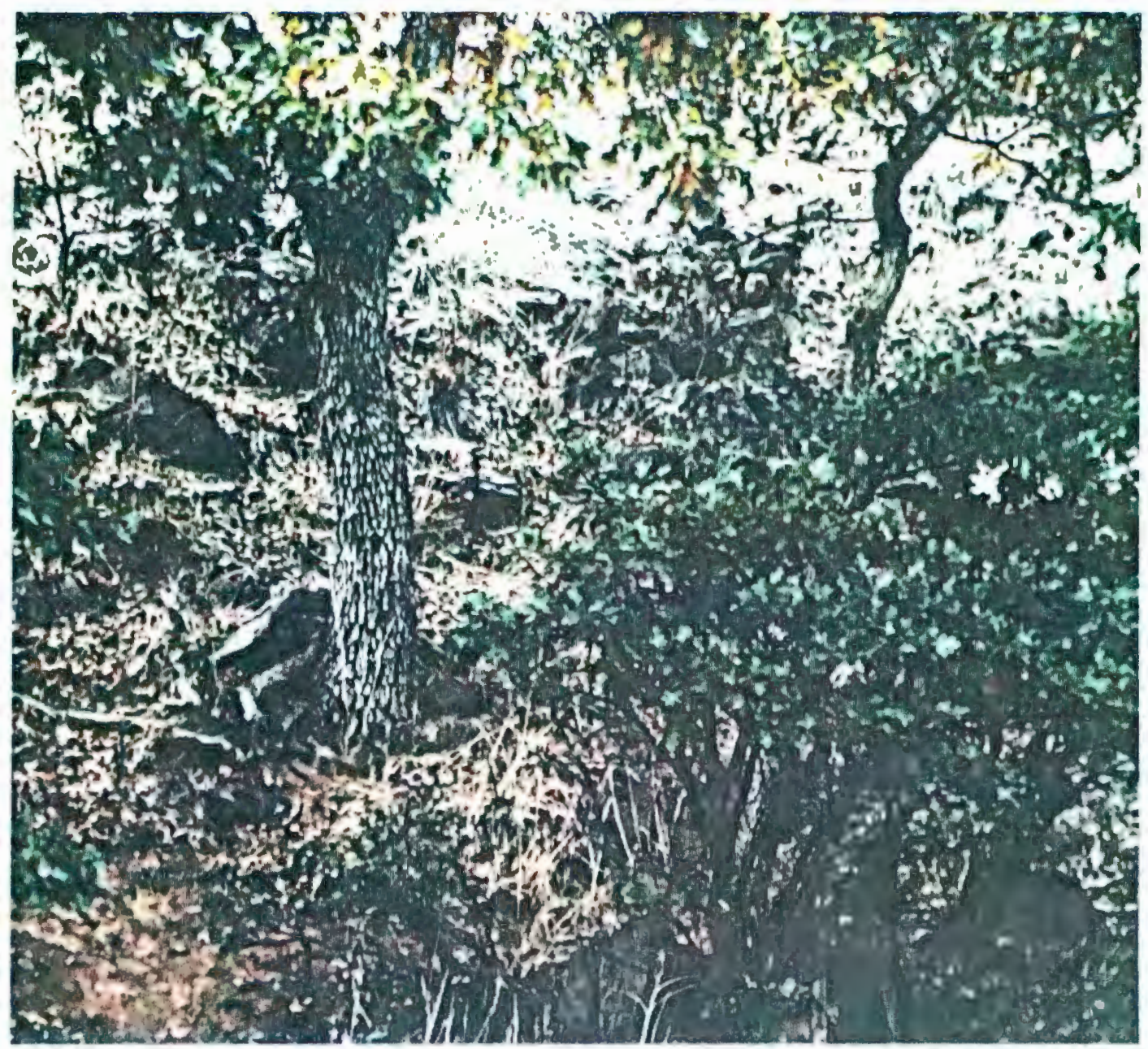

Figure 42. This north-facing slope in Butler Canyon (site \$5) exhibits abundant coppice regeneration (note right foreground) 
1950), resulting in steadily increasing reproduction until recent times. Thus, while oak's reproduction here fits a climatic model, fire may be an equa1ly important factor.

Site 14 exhibits excellent conformity to the reverse J curve (Figure 24). Neither severe drought nor precipitation increases seem to be manifested in size-class variations. The single older individual, propogated in approximately 1881, is outside of possible climatic comparison.

The size-structure for site 15 exhibits good correlation with the reverse $J$ curve (Figure 25) with the exception of the class between 12 and $18 \mathrm{~cm} \mathrm{dbh}$, or from 1925 to 1937 . This gap in regeneration correlates with the 1930 s drought. The presence of healthy Agropyron spicatum bordering this small oak stand signifies that oak is at the arid periphery of its range. Thus, the drought worked against oak regeneration, while earlier and later moisture surpluses favored it.

SITES WITH A NEGATIVE SIZE-STRUCTURE VERSUS CLIMATIC CORRELATION

Oak's size-structure at site 1 (Figure 4) shows complete cessation of regeneration after the $5 \mathrm{~cm}$ dbh class. Estimating the recovery (or invasion) of oaks at $5 \mathrm{~cm}$ (1951), this period correlates with resumption of normal and above-normal rainfa11 after the 1930 s drought (Figures 35 and 38). Precipitation averaged $75-100 \mathrm{~mm}$ above normal at this time. It is improbable, however, that climate alone would have completely eliminated such a drought-resistant species as oak. In light of the accompanying size-structure success during this period for Douglas fir and ponderosa pine (Figures 5-6), both of which are less drought-tolerant species than $\underline{Q}$. garryana, some other factor, such as fire must have 
taken its course during this period. This site did, however, show strong slope-aspect vegetational differences; the more mesic species occurring on the north facing slope while oak and grasses dominated the south facing slope.

The disjunct population of Oregon white oak at site 4 (Figure 12) demonstrates a pronounced departure from the reverse $J$ curve at the 25-30 $\mathrm{cm}$ dbh class. The precise termination of regeneration occurred at $31 \mathrm{~cm}$, or near 1902. The climatic records do not extend back this far. Regeneration, however, has not taken place since the turn of the century, while the population appeared stable prior to this period. The indication, then, is that a continuous restraint other than climatic change has affected the population since 1902 .

The oaks at site 8 (Figure 18) exhibit a sporadic size-structure. This population is dominated by the presence of some very old trees and a total lack of regeneration after the $20 \mathrm{~cm}$ dbh size class, or near 1923. Since regeneration did not take place during the 1930 s drought, nor during the earlier or later drier periods, some other factor is obviously overriding the climate-plant relationship.

The transect at site 9 sampled another section of the oak population found at site 8 . The size-structure is again characterized by an erratic distribution of size-classes (Figure 19) culminating in the total lack of regeneration after $19 \mathrm{~cm} \mathrm{dbh,} \mathrm{or} \mathrm{near} 1924$. These fluctuations do not correlate with either above or below-average precipitation. As in the previous case, climate does not appear to be the overriding factor at this site.

The size-structure of site 10 shows two distinct periods of 1 imited regeneration (Figure 20). One occurs at $23 \mathrm{~cm} \mathrm{dbh}$, or near 1917 , 
the other at $15 \mathrm{~cm} \mathrm{dbh}$, or near 1932. The 1917 variation agrees with a period of copious precipitation (Figures 35 and 38), while the 1932 variation correlates with the 1930 s drought. Considering the low elevation - $550 \mathrm{~m}$ - and the surrounding grassland habitat, the drop in regeneration associated with the 1930 s drought would seem reasonable. In order to associate a surplus of precipitation with a drop in oak regeneration, however, some other arboreal species, either Douglas fir or ponderosa pine, would need to be competing with oak; neither of these trees occurs at the site. Thus, another factor other than climate was operative in order to account for the cessation of regeneration near 1917.

The size-structure graph for site 11 elicits two variations from the expected reverse $J$ curve (Figure 21). First, while only one individual in the $36-40 \mathrm{~cm}$ dbh class occurred in the transect $(36 \mathrm{~cm}$, or near 1892), other equally old trees were seen scattered sparsely throughout the area, especially in the draws. While the climatic data does not reach this period, the lack of oak regeneration for a full 25 years after this time precludes a purely climatic explanation.

Second, the renewal of reproduction occurred in the $10-22 \mathrm{~cm}$ dbh class, or between 1919 and 1942. This time span covers both the 1930s drought and the period of precipitation surplus preceding it. There are not nearby pines or Douglas fir to compete with the oaks; thus, the oak reproductive increase during the moisture surplus is more expected than during the drought. Likewise, a lack of regeneration occurred under moister conditions from 5-10 cm dbh (or approximately 1942 to 1951 Without competition from more mesic species, this drop in regeneration is not explained by simple climatic corre- 
lation.

The size-structure of site 12 (Figure 22) resembles that of Figures 18-19. The only difference is the presence of recent regeneration at site 12 . The immediate cessation of regeneration of reproduction at $15 \mathrm{~cm} \mathrm{dbh}$, or in 1932, correlates with the 1930s drought. Since the population is on the arid periphery of oak's range, the regenerative reduction during the long period of drought is anticipated. What is not explained is the lack of regeneration after the drought up until recent times. Another factor must be dominating the climatic factor during this latter period.

The size-structure of site 13 fits the reverse $J$ curve (Figure 23) with the exception of oaks that are younger than $6 \mathrm{~cm} \mathrm{dbh,} \mathrm{or} \mathrm{since} 1949$. This correlates with a period of above-average precipitation (Figure 35). Since there are not other competing trees, this regeneration reduction is not explained by the climate graphs.

A situtation not made apparent by the size-structures at site 13 is the great density of oak, especially in the $6-19 \mathrm{~cm} \mathrm{dbh}$ class (see Figure 43). This abundance resembles that noted at site 7 for ponderosa pine. Weaver (1950) related this situation to removal of fire from the ponderosa pine ecosystem. and it is possible that this same situation applies to $\underline{Q}$. garryana.

COMBINED SIZE-STRUCTURE DATA VERSUS CLIMATIC CORRELATION

Figure 28 represents the summed oak size-class results for all of the sampled sites. Two aberrations from the reverse $J$ curve are apparent: one at $45 \mathrm{~cm} \mathrm{dbh}$ (approximately 1875) and the other between 3 and $11 \mathrm{~cm} \mathrm{dbh}$ (from 1940 - 1965). The first variation is beyond the 


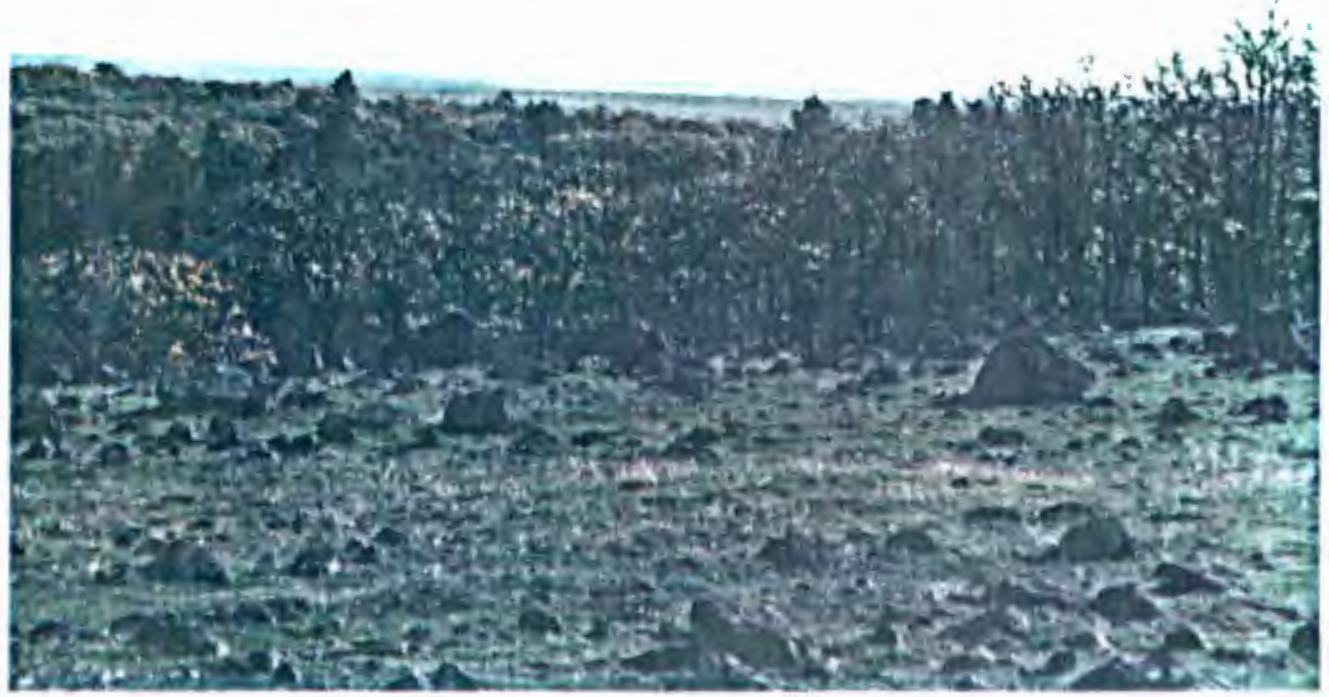

Figure 43. Scrubby Oregon white oak stands are punctuated by sporadic Douglas fir near Mosier Creek. 
scope of climatic comparison while the second covers too long of a time span to be explained by any single climatic variation. The data, however, covers both the arid and moist periphery of oak's range; thus, opposite reproductive responses would be expected to cancel out any meaningful variations from totally summed results.

\section{SLOPE ASPECT VERSUS CLIMATIC CORRELATION}

The size-structure data are separated into north and south facing slope results in Table III and graphed in Figures 26-27. On each graph, only one size-class varies from the expected reverse $J$ curve. On the north facing slopes (Figure 26), the 6-10 cm dbh size-class, or from 1942 - 1950, shows an appreciable drop in reproduction. This correlates with the increase in precipitation during the 1940s, especially fall precipitation figures (Figure 38), which are important to fall germinating species such as $Q$. garryana. This situation is consistent with the interspecific competition expected from Douglas fir and ponderosa pine on the mesic habitats during moist periods. Likewise, oak regeneration is relatively more active during the drought when more mesic species are apt to suffer from drought stress (Figure 44).

The summation of south facing slope size-class data in Figure 27 reveals a different situation. The size-classes from $6-10$ and $16-20$ cm dbh, covering 1943 - 1950 and 1922 - 1930, both show good reproductive rates and correlate with periods of above-average precipitation. Due to the increased aridity on south facing slopes, oaks exist on the tenuous edge of environmental exclusion. Thus, any increase in mean precipitation would result in increased oak regeneration. The sizeclass 11-15 cm dbh, covering 1932 - 1940, shows a good reduction in the 


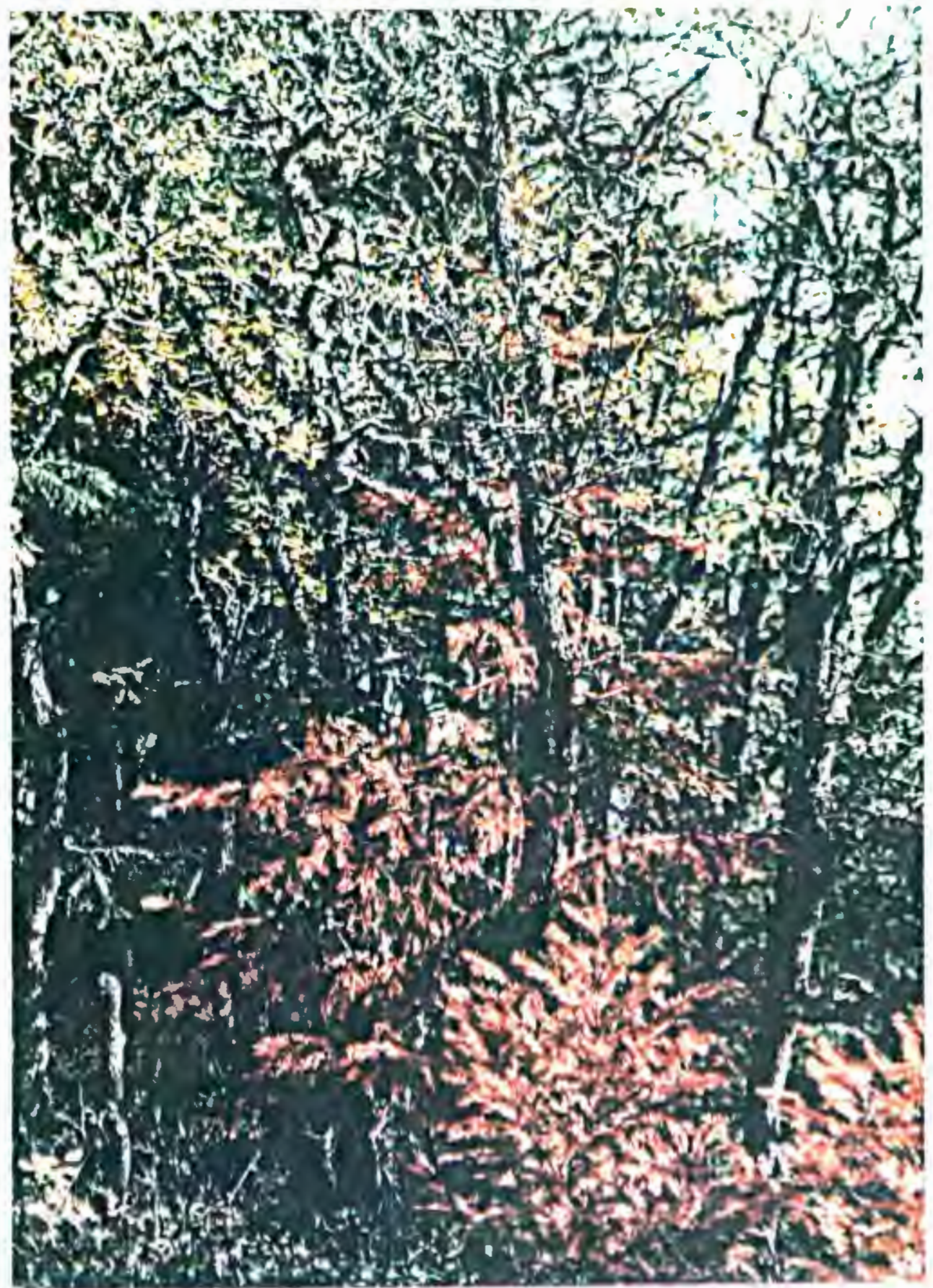

Figure 44. During the 1977 drought, Douglas fir trees frequently died while surrounding oaks survived. 
number of individuals, which correlates with the 1930 s drought. Thus, the mositure stress in this austere environment becomes a limiting factor to oak regneration during times of below-normal rainfall.

\section{SUMMARY}

The size-structure data for Oregon white oak correlates to some extent with climatic data. Oak occurs between the $300 \mathrm{~mm}$ mean annual isohyet at its arid frontier and the $1500 \mathrm{~mm}$ isohyet at its moist periphery. This great range in tolerance is partly a result of climatic amelioration resulting from topographic heterogeneity.

Climatic fluctuations correlate with some transect data but not with others. At the moist edge of its range, interspecific competition from Douglas fir and ponderosa pine is apparently limiting oak's growth and reproduction during wet periods, while arid periods favor oak reproduction. At its arid border, competion for the dwindling moisture resource forces oak to yield to xerophytic species during times of drought, while moister periods favor its reproduction. Thus Oregon white oak's population is constantly jockeying for reproductive dominance with its two plant association adversaries.

In the following chapter, those size-structures which did not exhibit good climatic correlation will be considered in light of grazing pressure in central Oregon. 


\section{CHAPTER VII}

\section{EFFECTS OF GRAZING ON OREGON WHITE OAK}

\section{INTRODUCTION}

Grazing is an integral process in most natural ecosystems. Photosynthetic energy is shuffled through the food chain via plants to herbivores, carnivores, and ultimately reduced through microbes to nutrients for plants. Thousands of years of co-evoloution between the members of these communities has resulted in smoothly operating, mutually dependent systems, whereby grazing is reciprocally necessary for both the plant and the animal (Gilbert, 1980).

Man has altered the natural producer-consumer relationships of many areas by the introduction of domestic livestock. In natural ecosystems, the vertebrate grazers can move to other habitats, or perhaps enter a state of torpor when preferred forage becomes scarce. When grazing is controlled, as in farm woodlots or pastures, however, domestic livestock may be forced to continue grazing after the more palatable plants have been exhausted. Under such conditions, those plant species which are intolerant of these pressures will be reduced or eliminated, leaving a less diverse plant community of more tolerant elements. Continued heavy grazing will eliminate all but the weedier species, which are frequently exotics. Finally, continued grazing may result in the elimination of even these aliens, leaving the site stripped clean of vegetation and with a potentially serious erosion problem (Whittaker, 1975).

In the study area, domestic livestock grazing reached its maximum 
intensity around the turn of the centruy. The extension of widespread private ownership through the Homestead Act soon afterward brought an end to the open range (Galbraith, 1971). By this time, however, there were serious overgrazing problems in central Oregon (Cholis, 1952; Cotton, 1904).

It is difficult to determine the functional importance of specific herbivores in oak habitats. Griffin (1976), working in a California oak woodland which was free of livestock grazing, constructed both deer and gopher exclosures for this purpose. Several herbivores were found to serious1y limit regeneration in Quercus lobata, but no one of them was found to be primarily responsible.

\section{GRAZING OBSERVATIONS}

Several vertebrates were observed transporting, burying, or consuming acorns in central Oregon (Table IX).

\section{TABLE IX}

ANIMALS OBSERVED CARRYING OR EATING ACORNS

Species

Douglas' Squirrel

Western Gray Squirre1

Blue Jay Number of Observations

2

2

Steller's Jay

17
Activity

Burying acorns

Carrying acorns

Carrying acorns from seed tree to another oak and consuming the acorns

Carrying acorns from seed tree to another tree (often conifer) and eating or occasionally dropping acorns. 
TABLE IX (Continued)

ANIMALS OBSERVED CARRYING OR EATING ACORNS

Species

Lewis' Woodpecker

Deer
Number of Observations

9

6
Activity

Carrying acorns from seed tree to another tree and: 1) eating acorns; 2) dropping acorns; 3) cramming acorns into tree cracks. Browsing under oak trees.

In addition, the terminal buds and bark of oak sprouts and saplings were found on occasion to be nibbled off.

Insects also graze in Oregon white oak communities. Oak galls bearing gall wasp larvae were commonly observed. In addition, a large percentage of the mast production found under oak canopies were infested by insect larvae, thus probably rendering them inviable.

Most or all of these herbivores were members of the Oregon white oak community during periods of both normal and abnormal reproduction, as depicted by the size-structure graphs (Figures 4-25). Records of variations in wildlife densities are, however, not available; their impacts on forest equilibrium are thus not known.

There is little doubt that selected vertebrate herbivores play an indispensible role in plant regeneration. Janzen (1970, 1971) notes that seeds accumulating under the canopy of the parent tree are rapidly consumed by animals, while those passively transported away be seed-storing vertebrates have a better chance of survival. It is plausible, then, that the actions of jays, woodpeckers, and squirrels may be an important element in Oregon white oak reproduction and diffusion. 
Man may indirectly affect oak reproduction by the manipulation of native wildlife populations. In Oregon, many members of the upper trophic levels have been eliminated through hunting, predator control and toxic pesticide use. The grizzly bear, wolf, wolverine and various raptors have been either completely or largely extirpated. In many cases, this has released the predation on the herbivores, resulting in a rise in population densities. Increased grazing by these animals, in turn, may have resulted in increased acorn consumption and thus reduced oak regeneration.

The consumption of acorns, terminal buds, and leaves by livestock was not directly observed. Ranchers living in the area were divided on the question, one noting that:

Hell no, cattle won't eat any part of these oaks! They aren't good for anything.

while another said that:

Sure, they prefer oak shoots and acorns over the other shrubs. They love them:

It may be assumed, however, that livestock do graze on oaks, considering the abundance of incriminating evidence (DenUh1, 1945; Griffin, 1976, 1977; Holland, 1976; Smith, 1957; Steinbrenner, 1931).

Among the fifteen sites surveyed, several showed signs of heavy livestock pressure, such as browse lines on the trees, churned-up soil, and little or no herbaceous vegetation. Other sites showed no grazing evidence, while still others showed slight evidence. The division of sites based on grazing pressure is shown in Table $\mathrm{X}$.

In order to relate the impact of livestock grazing pressure to Quercus reproduction, the grazing evidence is cross-matched with the climatic evidence, which is divided in Table XI between sites that did 
TABLE $X$

OBSERVED EFFECTS OF GRAZING

Heavily Grazed

Site \# $\quad 4,8,9,10$
Lightly Grazed

$5,11,12$
Ungrazed

$1,2,3,6,7,13,14,15$

or did not show positive correlation to the climatic data.

TABLE XI

COMPARISON OF CLIMATIC DATA TO SIZE-STRUCTURE

\section{Correlation No Correlation}

Site 非 $2,3,5,6,7,14,15 \quad 1,4,8,9,10,11,12,13$

Comparison of Tables $\mathrm{X}$ and $\mathrm{XI}$ reveals a $75 \%$ overlap between the ungrazed sites and the sites showing positive climatic correlation. On1y $25 \%$ of the ungrazed sites showed no climatic correlation. Further, among the sites exhibiting signs of heavy grazing, none showed good climatic correlation. This indicates that heavy livestock grazing is disruptive to the climate-plant reproductive relationship.

Closer scrutiny of the four heavily grazed sites reveals another common characteristic; all showed a complete absence of oak regeneration following a period of apparently healthy reproduction. The timing of this event was: site 4 - 1902; site 8 - 1923; site 9 - 1924; and site 10 - 1917. Whatever is stopping oak regeneration in these stands has been continuously operative for 50-75 years.

The soil condition and the herbaceous cover further reveals the effects of livestock grazing. All of the ungrazed sites exhibited soil profile development, except where trees grew directly out of bare basalt. 
The heavily grazed sites, however, showed an undifferentiated soil profile which when wet became a pasty mud. Further, low-growing plants were not present at heavily grazed sites, while ungrazed sites were moderately to lushly vegetated.

The grazing history of the study area is incompletely known. Site 15, however, has not been grazed by livestock according to the land owner and shows excellent correlation to the precipitation data. Nearby is another parcel of oak woodland which is divided by a road, one side of which is inhabited by only old-growth oaks larger than $10-15 \mathrm{~cm} \mathrm{dbh}$. There are, however, many recently sprouted acorns, the ground being literally a carpet of young Quercus seedlings. The owner attests that this site is regularly used to pasture livestock, but that it had not been so used for several months. Thus, heavy livestock grazing appears to directly inhibit oak regeneration and, although the soil may be badly churned by the cattle's hooves, rapid acorn regeneration can take place if grazing pressure is removed. Weaver (1950) and Rumnel's (1951) suggestion that heavy livestock grazing could, by breaking up the sod layer, increase the chances of seedling survival, is in accordance with these findings.

At the same site, on the other side of the road, the oaks appear to have a stable size-structure, with both young and old individuals being present, and the shrub and herbaceous layers are luxuriant. According to the property owner, the land had not been grazed during his 20 years of ownership. Very little acorn regeneration is apparent. The sod layer is relatively tight and may be limiting the number of seedling radicles able to penetrate the solum. Thus, some disturbance to the 
herbaceous layer may occasionally be necessary for extensive acorn regeneration to occur. Such a situation might have been created in the past by low Intensity ground fires which, as recorded by Keen (1937), occurred every 7-12 years in central Oregon prior to man's fire-prevention efforts.

\section{SUMMARY}

Q. garryana communities are grazed by indigenous herbivores and domestic livestock. The functional role of native grazers is problematic, although it is reasonable to assume that acorn dispersal by vertebrates is important for oak reproduction and population movement.

Livestock grazing is strongly correlated with uneven size-structures in Oregon white oak communities. The consumption of seedlings apparently limits oak's ability to replace itself. The long-term effects of this practice may be the elimination of Quercus from these sites.

The accumulation of organic duff and the tight sod layer may have historically allowed only infrequent acorn regeneration. Acorn sprouts, however, were found to quickly take root in overgrazed areas when the livestock grazing pressure was removed. Such areas apparently provide easy access to the mineral layer for the seedling radicles. Before human fire-prevention activities, similar soil disturbances and hence productive seed-beds may have resulted from the low-intensity ground fires which periodically swept the area.

Many vertebrates transport acorns away from the seed tree as part of their grazing behavior, thus conceivably acting as vectors of seed dispersal. Inasmuch as plant species require some means of population mobility, particularly during periods of environmental stress, this ac- 
tivity becomes an integral element in Oregon white oak's biogeography. The following chapter will explore the relative effectiveness of animals, physical processes, and man as agents of acorn movement. 
CHAPTER VIII

VAGILITY OF OREGON WHITE OAK ACORNS

\section{INTRODUCTION}

In order to survive periods of radical environmental change, plants must possess the ability to either adapt to the new conditions or migrate away to suitable areas. Seeds, which provide the means for population movement, are as a normal course disseminated to both favorable and unfavorable habitats; those which survive may live to act as seed sources for diffusion into further amenable areas. Such a process, if carried on quickly enough to keep pace with changing conditions, will allow a population to migrate in the general direction of favorable environmental conditions and thus escape extirpation.

In Quercus, the adaptive value of acorn dispersal mechanism are manifold. Seed trees, which act as red flags for local herbivores, bequeth a slim chance of survival upon acorns that congregate under the tree canopy. Seeds that escape consumption here must further face a competitive battle with the mother tree, which would seldom tip in favor of the youthful aggressor. And subtle factors such as allelopathic inhibition, while not documented in Quercus, might further hinder the germination of acorns in the immediate vicinity.

Q. garryana cannot be considered a swiftly migrating species due to the bulky size and weight of its seeds. Spore producing life forms, which produce millions of wind dispersed propagules, enjoy wide distributions. Plants with sticky seeds or tasty fruits are adapted to dispersal by migrating birds and mammals. Acorns, however, are not wind 
dispersed, can seldom be swallowed whole by birds, and do not cling innocuously to animal appendages. Oak seems to have sacrificed copious seed production and physical conveyance for increased nutritive value, physical protection, and specialized transport by a few vertebrate species. The endosperm, which makes up most of the seed, has a high content of protein and fats, thus supplying an ample reward for species adapted to their consumption.

Several means of acorn transport were examined within the study area. The effectiveness of gravity fall and hillside roll is considered, as well as flotation by running water. Particular attention is paid to the function of birds and mammals in acorn mobility. Finally, the role of humans in acorn transport is explored in an historical context.

\section{GRAVITY FALL AND HILLSIDE ROLLING OF ACORNS}

In order to measure the effectiveness of gravity fall and hillside roll as a dispersal mechanism, the acorns of an oak approximately 116 years old were painted in the fall. The following spring, a thorough search produced 41 acorns. The distances and directions of the seeds from the host tree, as well as calculations of the mean and maximum dispersal distance, either upslope or downslope, are listed in Table XII.

The results show that the majority of the retrieved acorns - a1most $70 \%$ - fell and rolled downhill (Figure 45). The distance covered, however, was not dramatic, the maximum distance being $665 \mathrm{~cm}$ from the trunk. The tree canopy spread $460 \mathrm{~cm}$ in each direction from the trunk. Thus, the farthest dispersed acorn traveled just over $2 \mathrm{~m}$ beyond the tree canopy. The mean distance traveled places most of the propagules well within the limits of the canopy. The mean upslope distance covered 
揭

岪 品

된

总 ज्ञा

矛密离

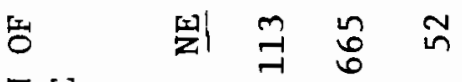

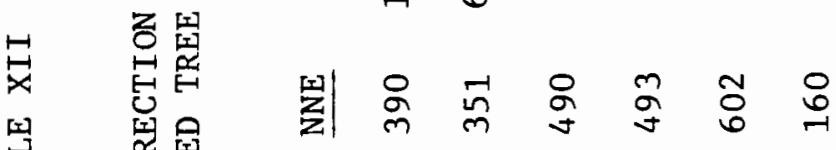

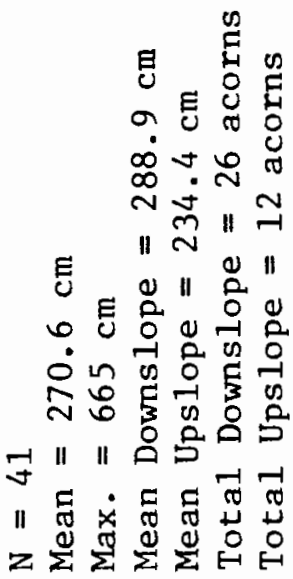

畄思

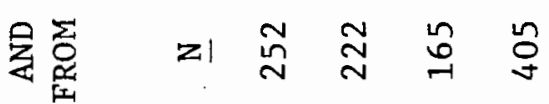

焉

部品吕

跑

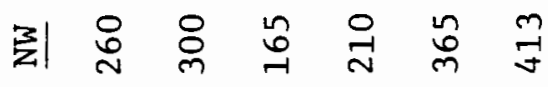

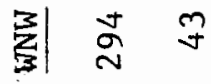

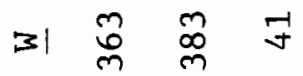

须

하 :

矛寺

w 


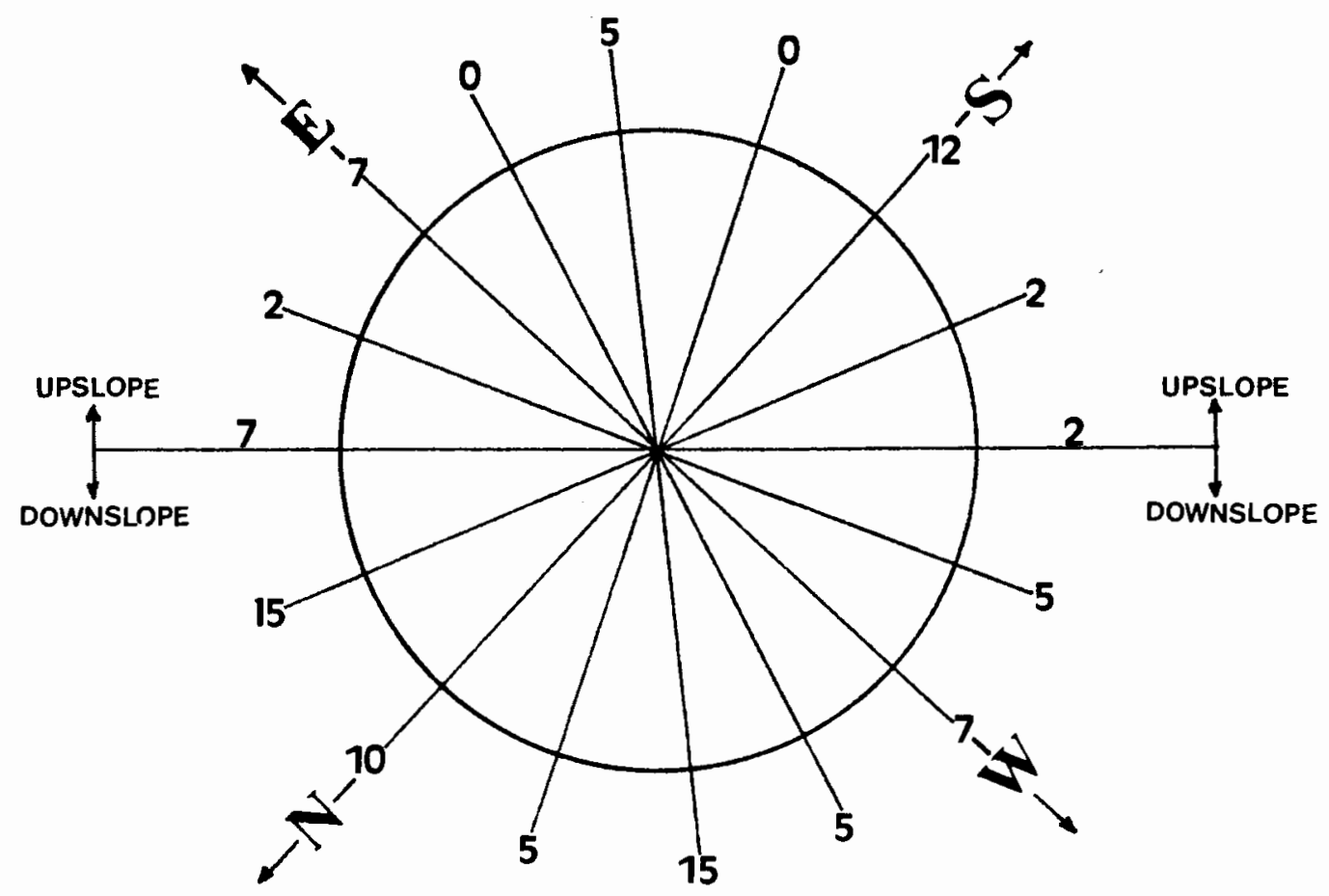

Figure 45. The location - by percent of total - of recovered acorns under an Oregon white oak tree (see Table XII). 
was $234.4 \mathrm{~cm}$, while the mean downslope distance was $288.9 \mathrm{~cm}$. The seeds moved downslope thus averaged over $50 \mathrm{~cm}$ farther from the trunk than those transported upslope. Considering predation by herbivores and competition with the seed tree, it seems safe to assume that few acorns simply fall to the ground and roll to a safe germination site, although downslope movement would be relatively more effective than upslope.

In order to calculate maximum potential dispersal rates by falling and rolling, an acorn will be hypothetically allowed to move the maximum noted distance of $665 \mathrm{~cm}$ from the mother tree, germinate, and grow into a seed-producing oak in approximately 25 years. If this sequence of events is repeated for 100 years (if the original tree is at the edge of the population, and if the acorns are carried directly away from the main population), the Oregon white oak population would have migrated $2.6 \mathrm{~cm}$; if continued for 1000 years, this would account for a $226 \mathrm{~m}$ range extension. While differing canopy size, slope inclination, and a host of other factors could alter this rate somewhat, the fact remains that gravity fall and roll of acorns is a slow means of oak population migration.

It was further noted that eight of the forty-one acorns had been broken open and consumed. These propagules were located an average of $220 \mathrm{~cm}$ from the tree trunk, which is less than the overal1 mean and even the upslope mean. Thus, in this case, nearness of acorns to the seed tree seems to work to the detriment of seedling survival.

\section{RUNNING WATER TRANSPORT}

Three criteria must be met for running water to aid in acorn dispersal: 1) the seed tree must grow close enough to the stream course 
for acorns to reach it; 2) the acorns must float or be dragged in the current for some distance without becoming waterlogged; and 3) the seed must be deposited at a safe site for germination.

In order for the first criterion to be consistently met, Oregon white oak would have to be a riparian species. While this is not generally the case, it does in some instances grow adjacent to drainages.

If the acorns are less dense than water, the stream would have little problem transporting them; if, however, they are heavier than water, the current would need to be swift enough to hold the seeds in suspension. This question was answered in a cursory manner by dropping 20 acorns into a creek; they immediately sank to the bottom. This was probably too small of a sample to positively disregard water flotation of acorns, and Ridley (1930) speculated that even a $4-8 \%$ rate of successful flotation in a European species of oak was sufficient to consider it a viable means of acorn transport. Generally, however, acorns are not able to tolerate long periods of water immersion, although Kramer (1960) found that the seeds of some oak species can remain submerged up to two months and still maintain viability.

The third criterion requires that floating acorns drift to a suitable site for germination and growth. The potential for this is not known, but considering the lack of oaks growing at streamside, it appears that $Q$. garryana may not be competitive in riparian habitats.

A severe flood might circumvent some of these limitations. A large volume of water traveling down a drainage system would reach and occasionally engulf oak trees. Acorns carried by a flood state volume of water would have the advantage of possibly being deposited on the lateral side of the levee. The scouring action of the flood, by removing stream- 
side vegetation, might also be preparing a suitable seedbed. This, however, is purely speculative.

\section{ANIMAL TRANSPORT OF ACORNS}

The movement of acorns by animals is an important factor in oak migration. Several species were noted to cache or otherwise drop viable acorns, including: Steller's jays (Cyancitta stelleri), blue jays, (Cyanocitta cristata), Lewis' woodpeckers (Asyndesmus lewis) and Douglas' squirrels (Tamiasciurus douglassi).

Douglas' squirrels were observed carrying acorns only twice and on both occasions they were carried approximately $8 \mathrm{~m}$ and buried. I retrieved these acorns and they appeared perfectly viable. They were buried about $2 \mathrm{~cm}$ deep, which should have greatly increased their potential for germination (Korstian, 1927). Thus, if Douglas' squirrels do occasionally fail to retrieve a cache, this would seem to be an effective mode of seed dispersal. It is not, however, a long distance means of dispersal.

Two blue jays were sighted at Oak Springs Fish Hatchery on 8 October, 1977. Although they were observed transporting acorns approximately $300 \mathrm{~m}$, this species is not considered to be important in acorn dissemination, as it is considered an accidental species in this area.

Steller's jays were frequently seen carrying and dropping acorns. After grasping the seed in $i$ ts beak, it commonly flies to a nearby conifer and eats or drops the seed. In addition, it of ten partook in a "musical chairs" type activity, whereby one jay would land in a tree, thus displacing the previous occupant, which in turn would fly to another tree and eject another jay, and so on; one or more seeds were dropped 
in these exchanges. It is important in respect to progagule dissemination that Steller's jays did not retrieve fallen acorns.

It was also observed that Steller's jays would fly to either a Douglas fir or ponderosa pine to consume acorns; areas not inhabited by conifers as well as oaks were devoid of Steller's jays. Since conifers generally exist upslope relative to Oregon white oak, Steller's jays may be important vectors of upslope dispersal. Oak's linear extension up the south facing slopes of creek drainages into the Douglas fir zone may be dependent on this actitivity.

Lewis' woodpeckers, which do not participate in the typical woodpecker activity of hammering into tree bark seeking insects, seem to subsist on acorns and flight-captured insects (see Figure 46). They exhibit different behavior with respect to acorn consumption than do Steller's jays; they fly to oaks or western junipers as opposed to Douglas fir or ponderosa pine to eat acorns. This tree preference implies that Lewis' woodpeckers may be important modes of oak diffusion beyond the arid periphery of its range. Population extensions such as along Fifteen Mile Creek or Oak Brook Canyon may be the result of this activity. Lewis' woodpeckers also cache large numbers of acorns in the crevices of trees and telephone poles (Figure 47). Viable-looking acorns were found lying on the ground under these seed storage areas.

Birds appear to be more effective agents of long distance dispersal than western gray squirrels. Lewis' woodpeckers were observed carrying acorns an average of 30-50 m, while Steller's jays transported them approximatley 80-100 m. On several occasions, Steller's jays were seen moving acorns $300-400 \mathrm{~m}$ before landing. Utilizing the same method as was used to calculate the rate of population movement by gravity fall 


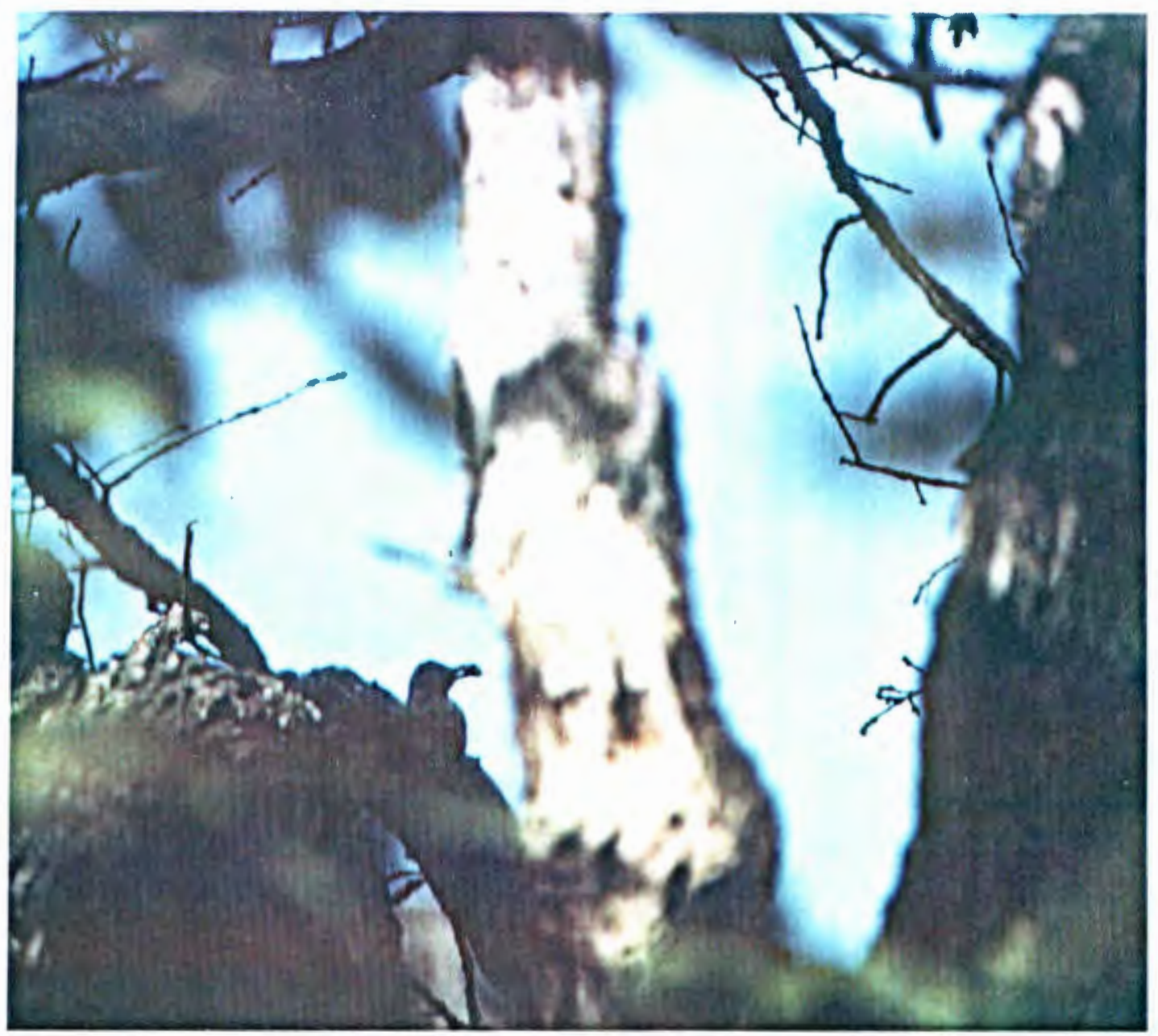

Figure 46. Lewis' woodpeckers commonly carried acorns to other oak or juniper trees, where they cached or consumed them. 


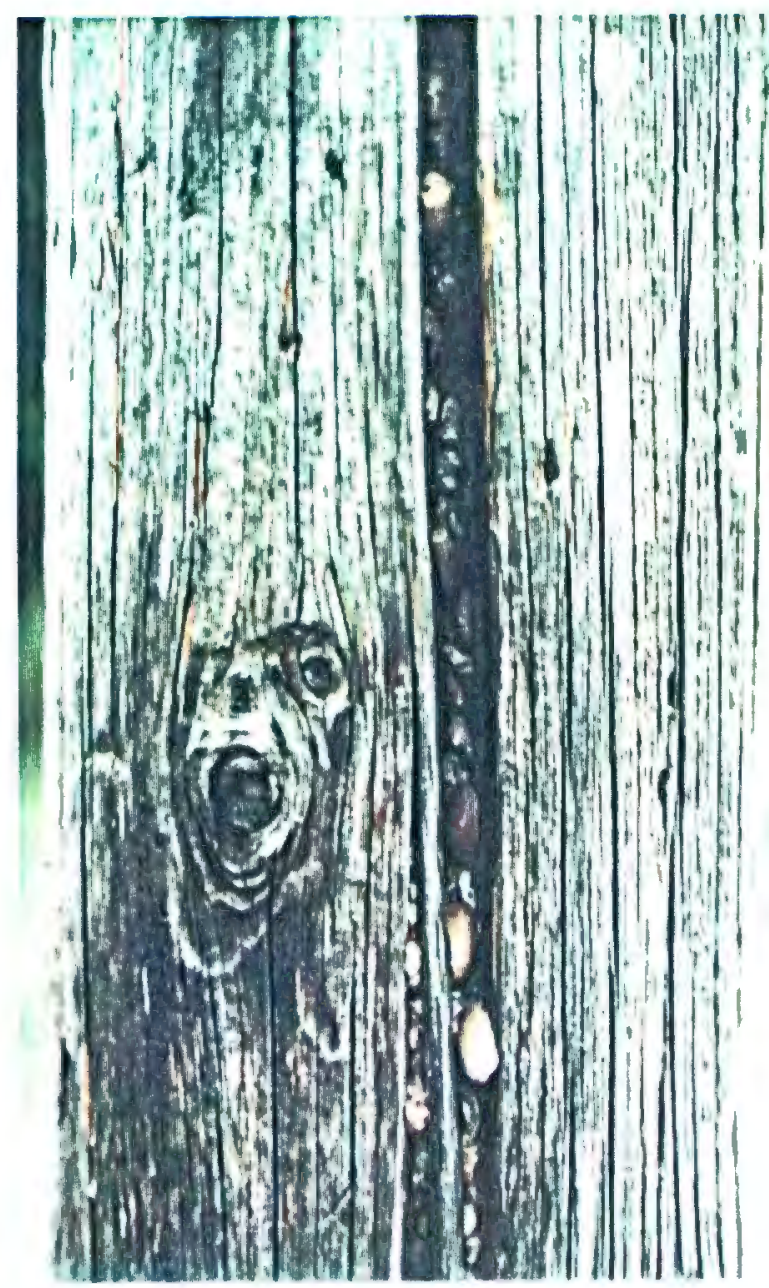

Figure 47. Lewis' woodpeckers stored viable acorns in the crevices of trees and telephone poles. 
and roll, and by allowing Steller's jays a maximum of $500 \mathrm{~m}$ per carry, the swiftest rate of Oregon white oak expansion into a new habitat would be $2 \mathrm{~km}$ per 100 years, or $20 \mathrm{~km}$ per 1000 years. For Lewis' woodpeckers, given a maximum of $200 \mathrm{~m}$ per carry, the rate of migration would be $400 \mathrm{~m}$ per 100 years or $4 \mathrm{~km}$ per 1000 years. These figures will later be used to calculate potential post-Pleistocene migration rates.

\section{MAN'S ROLE IN ACORN DISPERSAL}

Humans have historically been active agents of plant dispersal. Transport methods have been as overt as the repeated attempts to introduce pheasant into North America, or as innocent as some insect introductions :

A friend of a friend of mine who had just returned from Europe was rather astonished when small beetles began to hatch out of his shirt buttons. These turned out to be made from the nuts of a kind of palm, and the larvae had gone on living in the stuff, having apparently passed through the manufacturing process without harm. (E1ton, 1958, p. 3)

The Wasco-Wishram Indians, a Chinookan speaking group originally situated on the Columbia River within the study area, manufactured implements from oak wood and ate the acorns. Although of secondary importance to salmon, roots and seeds were gathered and consumed. And while acorns were popular food and trade items, it is stressed that:

The nuts [acorns] are not a staple, but were eaten at leisure moments, not at meals... (Spier and Sapir, 1930, p. 183).

Lewis and Clark's first observation of acorns came prior to the sighting of Oregon white oaks, about $25 \mathrm{~km}$ to the east of the John Day River:

We got from the people a few pounded roots, fish and acorns of white oak, those acorns they make use of as food 
raw and roasted and inform us they procure them of the natives who live near the falls... (Thwaites, 1904, p. 143).

Acorns, then, were a trade item transported in both viable and nonviable condition. Roasted acorns were made into special standardized packages, along with huckleberries and hazel nuts, for trading purposes (Spier and Sapir, 1930).

For Indians to have been agents of dispersal, it was necessary for the seeds to be transported in raw form. Most ethnographic evidence, however, points to the non-viability of these trade items. Lee and Frost (1844, p. 181) record the following preparation of acorns:

Acorns, also, which are abundant some years, are used as an article of food. These are gathered and baked with heated stones - a method of preparing food common to both the Indians and the Pacific islanders. Heated stones are put into an excavation in the ground 3 feet across, and covered with leaves or grass so as to protect the articles to be cooked from burning. Then these are laid on and carefully covered in the same manner. Last of all earth is spread over the hole to keep in the heat, and the process of baking is done up in real native style. After the acorns are thus prepared, deep pits are dug near the water, where they remain through the winter; when they are taken up and eaten, much improved, it is supposed, by the soaking process.

The Wishram used a similar process, although they also added the seed of a wild mustard to the mud mixture for flavor (Spier and Sapri, 1930). The leaching of bitter tannic acid would have rendered the acorns useless for germination. Neither process, however, explains Lewis and Clark's observation of "...raw..." acorns (Thwaites, 1904, p. 143). Methods for preparing acorns, however, differed widely west of the Cascades. The Chehalis prepared them much like the Wascos (Gunther, 1945) as did the Kalapuyas (Peterson, 1975). The Cowlitz ripened the acorns in mud without cooking them, while the Klallem ate them fresh:

Acorns are eaten raw after the shell is cracked and the meat pounded on a rock. (Gunther, 1945, p. 28). 
This is the only reference to the consumption of raw acorns.

\section{SUMMARY}

Plant species require the ability to migrate to favorable habitats during periods of environmental change. In Oregon white oak, large nutritious seeds, which are the preferred forage of several mobile vertebrates, provide the means of population movement through range extension. Douglas' squirrels, while burying acorns in suitable germination sites, do not carry acorns a great distance from the seed tree. Ste1ler's jays, which act as vectors of seed dispersal into Douglas fir and ponderosa pine zones, carry acorns for several hundred meters. Lewis' woodpeckers, which transport acorns to more arid habitats, move acorns a shorter distance than Steller's jays. Through the actions of these two bird species, strategically placed propagules are ready to take advantage of varying climatic conditions.

Acorns fall from trees and roll a short distance. This mode of dispersal is probably not very effective due to heavy predation by herbivores, competition from the mother tree, and the slow potential rate of movement by this method, which may not allow the population to keep pace with a rapidly changing environment.

Due to their tendency to sink in water, stream transport of $\underline{Q}$. garryana seeds probably seldom occurs. Flood conditions, however, might provide sufficient current and, through scouring action, an amenable seedbed for germination.

Although the Indians native to north-central Oregon - the WascoWishram group - consumed and traded acorns, their practice of roasting them prior to transport probably precluded these people from being 
active vectors of viable acorn dispersal. In the Willamette Valley, however, where at least one group is known to have eaten raw acorns, native groups may have been agents of acorn dissemination.

Oregon white oak has been shown to be a climax species in a state of reproductive equilibrium in central Oregon. Its disruption is climatically defined and its population status is in part a function of historic climatic changes and the introduction of livestock grazing. In addition, the different modes and potential rates of oak diffusion have been examined. In the following chapter, this information will be considered in conjunction with pollen evidence in order to shed light upon $\mathrm{Q}$. garryana's post-Pleistocene migrational history in central Oregon and throughout the Pacific Northwest. 


\section{CHAPTER IX}

\section{MIGRATIONAL HISTORY OF OREGON WHITE OAK}

\section{INTRODUCTION}

A plant's migrational pathway can be revealed by integrating the known temporal changes in climate of the area with a knowledge of the specie's climatic requirements, its historical presence in different areas, and its physical capacity to diffuse. In the following discussion, oak's migrational history will be proposed through consideration of its response to Hypsithermal warming, its entrance into the study area as determined by pollen evidence, and its intrinsic dispersal rates as calculated in Chapter VII.

\section{HISTORY OF THE VEGETATION IN THE PACIFIC NORTHWEST}

Hansen $(1938 ; 1940 ; 1941 \mathrm{a}, \mathrm{b} ; 1942 ; 1943 \mathrm{a}, \mathrm{b}, \mathrm{c} ; 1947 ; 1950)$ and Heusser (1960; 1964) surveyed the post-Pleistocene stratigraphy of the Pacific Northwest and reached much the same conclusion concerning the vegetational history of the area. At the close of the Wisconsin glaciation, the Willamette-Puget Trough was inhabited by lodgepole pine, Sitka spruce, and mountain hemlock. These forests were separated by patches of alpine vegetation(Detling,1958). As the glaciers receded, lodgepole pine quickly invaded the outwash plains, being replaced in time by western hemlock and Sitka spruce. The direction of migration was from south to north, although Pleistocene refugia for both Sitka spruce and western hem- 
lock may have been provided by nunataks on Queen Charlotte Island (Hulten, 1937) thus providing northern centers of dispersal.

As the climate warmed and dried, early invading species were replaced by more xeric trees, including Douglas fir and later Oregon white oak. When conditions reached their warmest and driest during the Hypsitherm, some 4000-8000 years b.p., Oregon white oak reached its greatest areal extent and density. Subsequent climatic cooling has led to a partial replacement of the xeric flora by more mesic species.

The anticipated replacement of the xeric flora was in part checked by the action of resident Indians. They burned large sections of the Willamette-Puget Trough which resulted in the retention of oak (due to fire tolerance) in many areas which otherwise would have been invaded by conifers. The elimination of burning in the Valley after the 1850s would have allowed much of the oak population to be supplanted by Douglas fir, had the land not been converted to agricultural and forestry land-use (Johannessen, et al., 1971).

\section{POLLEN INTERPRETATION}

The purpose of examining the pollen record is to pinpoint the chronology of Oregon white oak's migrational history. Puportedly, oak traveled in a northerly direction from California to British Columbia in response to the Hypsithermal warming period (DetIing, 1961; 1968). Although most of the pollen work was done prior to $\mathrm{C}^{14}$ dating methods and the accuracy of the chronologies presented by early workers has been challenged (Mack, et al., 1976), the pollen profiles do contain a reliable reference point in the 6600 years b.p. Mt. Mazama ash layer (Fryxa11, 1965; Rigg and Gould, 1957). 
Using data from 412 bogs, Rigg and Gould (1957) established a correlation between the age of pollen strata and the depth within the profile. Bogs located within the Puget Sound till area were found to accumulate peat at a rate of 41 years per inch (16.4 years per $\mathrm{cm})$; those outside of the area had a mean of 48.5 years per inch ( 19.4 years per $\mathrm{cm}$ ) for layers above the Mazama ash layer. In order to date oak's entry into an area, as evidenced by its presence in the pollen profile, several pollen cores containing oak pollen were interpreted using this correlation (Table XIII). Years were added to or subtracted from 6600 years, depending upon whether oak pollen appeared above or below the ash layer. Oak pollen layers within cores not exhibiting an ash layer were calculated by applying the age-depth correlation from the top of the profile. The pollen samples used in this interpretation are located from British Columbia to Oregon coastal areas and in the lowlands enveloped by the Olympic lobe of the Wisconsin ice sheet. The basin and pothole topography characteristic of the glaciated areas are particularly conducive to pollen stratification. More southerly areas in the Willamette Valley lack the necessary topography and, in addition, would have been thoroughly scoured out by the Missoula Flood of 13,000 b.p. (Al1ison, 1935; Bretz, 1925). Thus, much of 9 . garryana's pollen record is translated from the northern reaches of its range.

The chronological sequence so derived does not support the south to north migration hypothesis. The oldest pollen date comes from the Parkland bog in the Puget Sound, followed by the cores from the Willamette Valley well to the south. Sites on Vancouver Island, at the northern periphery of oak's range, yield early 9 . garryana pollen as do widely scattered sites. Younger oak pollen recordings branch out from the cen- 
TABLE XIII

CHRONOLOGY OF POLLEN STRATIGRAPHY

\begin{tabular}{|c|c|c|c|c|c|}
\hline $\begin{array}{l}\text { Dept } \\
\text { Ash }\end{array}$ & $\begin{array}{l}\text { th Below } \\
\text { Layer (cm) }\end{array}$ & $\mathrm{X}$ & $\begin{array}{l}\text { Depth/Age } \\
\text { Multiplier }\end{array}$ & $\begin{array}{l}+/- \text { Mazama } \\
\text { Ash Age (yrs) }\end{array}$ & $\begin{array}{l}\text { Total } \\
\text { (yrs) }\end{array}$ \\
\hline Parkland (a) & 620 & $\mathrm{X}$ & 16.4 & $+6,600$ & 16,798 \\
\hline Ronald (a) & 220 & $\mathrm{X}$ & 16.4 & $+6,600$ & 10,208 \\
\hline $\begin{array}{l}\text { Malahat (b) } \\
\text { Little }\end{array}$ & 0 & $\mathrm{X}$ & 16.4 & $+6,600$ & 6,600 \\
\hline Qualicum (b) & $100 *$ & $\mathrm{X}$ & 16.4 & 0 & 1,640 \\
\hline Pangborn & & & & & \\
\hline $\begin{array}{l}\text { Lake (b) } \\
\text { Whidbey }\end{array}$ & 150 & $\mathrm{X}$ & 16.4 & 6,600 & 9,060 \\
\hline Is land (b) & 0 & $\mathrm{X}$ & 16.4 & 6,600 & 6,600 \\
\hline Ozette Lake (b) & $200 *$ & $\mathrm{X}$ & 19.4 & 0 & 3,800 \\
\hline Seaview (b) & $100 *$ & $\mathrm{X}$ & 19.4 & 0 & 1,940 \\
\hline Garrison Lake (b) & Radioc & rbo & Eed & 0 & 6,500 \\
\hline Black Creek (c) & 210 & $\mathrm{X}$ & 16.4 & 6,600 & 10,044 \\
\hline Qualicum Beach (c) & 230 & $\mathrm{X}$ & 16.4 & 6,600 & 10,372 \\
\hline Langford Lake (c) & 320 & $\mathrm{X}$ & 16.4 & 6,600 & 11,848 \\
\hline Onion Flat (d) & 325 & $\mathrm{X}$ & 19.4 & 6,600 & 12,905 \\
\hline Lake Labish I (d) & 275 & $\mathrm{X}$ & 19.4 & 6,600 & 11,935 \\
\hline Lake Labish II (d) & 300 & $\mathrm{X}$ & 19.4 & 6,600 & 12,420 \\
\hline
\end{tabular}

Sources: (a) Hansen, 1938

(b) Heusser, 1960

(c) Hansen, 1950

(d) Hansen, 1942

* Depth is below surface; Mazama ash was not present in the profile. 
ter of oak's range toward coastal areas not presently inhabited. Thus, rather than incrementally moving northward with the improving postPleistocene climate, Oregon white oak appears to have been already inhabiting its current northern boundaries.

\section{HYPSITHERMAL RELICTS}

Another line of evidence for $Q$. garryana's migration comes from the existence of several disjunct "islands" of xeric vegetation (Detling, 1953). These isolated communities, which contain species commonly associated with more southerly regions, are considered to be reductional relicts of a once more liberally distributed association. The Hypsithermal warming and drying supplied an amenable climate for a northerly migration of these plant species, while the subsequent cooling of the last few thousand years has restricted this vegetation to a few favorable microhabitats. Oregon white oak's presence in the Pacific Northwest is attributed to the aformentioned Hypsithermal conditions. For this hypothesis to be true, oak must have advanced from California north through the Willamette Puget-Trough to Vancouver Island. The Klamath-Siskiyou Mountains, which would have presented a formidable barrier, may have been circumvented by following the Klamath River to the coast and then entering the Willamette Valley via the Umpua or Rogue River. Allowing this exodus to begin at Redding, California, Oregon white oak must have traveled over $1000 \mathrm{~km}$ to have reached its present northern frontier.

The proposed pollen chronology (Table XIII), if considered in light

* Redding was chosen because if Detling (1968) is correct in assuming that Pleistocene conditions were too severe for oak to have winteredover to the north of the Klamath-Siskiyou Mountains, this northern tip of the Central Valley may have been the first southerly site of amenable conditions. 
of the previously presented limitation of acorn dispersal rates, clearly show that $Q$. garryana did not migrate from California, as Detling (1953) has contended, during the Hypsitherm. Rather, if the maximum rate of acorn dispersal is $20 \mathrm{~km}$ per 1000 years as proposed (Chapter VIII), oak's post-glacial distribution must have closely paralleled its current northern reaches in order to have prospered so immediately after the Pleistocene. Over half of the sites contain oak pollen in the $10,000-12,000$ years b.p. range, which is contemporaneous with the cessation of Ice Age conditions at about 12,000 years b.p.

It is of course possible that either or both of the rates of acorn dissemination and the pollen chronology are incorrect. In the former case, jays or woodpeckers may transport acorns farther than observed in the study area. For this to be the case, however, the average maximum rate of diffusion would need to be greatly increased $(500 \mathrm{~km}$ per 1000 years for 2000 years as opposed to the projected $20 \mathrm{~km}$ per 1000 years) which would be equal to Stellers jays consistently carrying acorns 12.5 $\mathrm{km}$ per flight, which seems well beyond their capabilities.

Running water, which was relegated a minor role in acorn dispersal, may have been operative during the Missoula Flood, although this event could account for only a portion of the necessary acorn movement. This largest of all recorded deluges, dated at approximately 13,000 years b.p., burst through the Columbia Gorge from eastern Washington, carrying a mass of water and ice perhaps $300 \mathrm{~m}$ deep, raced up the Willamette Valley to near Eugene, depositing Rocky Mountain erratics up to the $100 \mathrm{~m}$ contour interval, and then continued westward into the Pacific Ocean. The flood could conceivably have carried acorns (not to mention entire forests) from the southern Willamette Valley and deposited them 
along the Willamette and Columbia River's drainages, which might account for at least $200 \mathrm{~km}$ of northern range extension. Another, although unlikely, possibility is that acorns were rafted out to sea, followed the longshore currents north up the Oregon and Washington coast, and finally came to rest on the shores of Vancouver Island. The non-viability of acorns in salt water, however, makes this a remote possibility.

The role of Indians as agents of acorn dispersal may be underestimated. Although the Wasco-Wishram group was largely discounted as a seed disseminator, the tribes in the Willamette-Puget Trough may have been more effective at this enterprise. Gunther (1945), for example, noted that the Klallem group in Washington ate raw acorns. While it is therefore plausible that living acorns were traded and occasionally dropped in viable form, this process would not have accounted for $1000 \mathrm{~km}$ of diffusion in 2000 years.

It is also possible that the pollen record is being misinterpreted and that Rigg and Gould's (1957) correlation is not valid. Regardless, oak pollen shows up in the profile below the ash layer, and thus was present prior to 6600 years b.p. Application of the acorn dispersal rates even to the Mazama ash layer does not account for dispersal all the way from California.

It can thus be safely inferred that Oregon white oak was present in the Willamette-Puget Trough during one or more of the Pleistocene ice advances, and that it could not have migrated from California in the short period of time available during the Hypsitherm.

As a sideline, it is worth noting that while $\underline{Q}$. garryana is the only representative of the genus Quercus in the Pacific Northwest, California black oak (Q. kelloggii) forms its northernmost stands along the 
Umpqua River in southern Oregon. If the dispersal rates estimated for Q. garryana are applied to California black oak (starting again at Redding, California), $20 \mathrm{~km}$ per 1000 years for 12,000 years (post-Pleistocene period) yields a potential $240 \mathrm{~km}$ movement, which places Q. loggii quite near its present northernmost range. Although application of acorn dispersal rates to a different species of Quercus loses some validity, it is at least plausible and thus adds some credibility to the estimated dispersal rates.

\section{CHRONOLOGY OF MIGRATION IN OREGON WHITE OAK}

Although the topography and climate of the study area does not lend well to pollen profile accumulation, predictions can be made concerning Oregon white oak's migrational history using previously presented information. First, oak could not have colonized the area during a period drier than at present. Previous size-structure data have shown that at best $Q$. garryana is maintaining a stable population throught its central range, and at the arid periphery of its range, it is limited by lack of precipitation. Thus, a period of increased aridity, such as the Hypsithern, would have forced an upslope movement and general retreat of Oregon white oak from central Oregon. Rather than increasing numerically during the Hypsitherm, as was the case west of the Cascades, oak would have generally decreased in number.

Second, oak was apparently not present in the Columbia Gorge after the Missoula Flood. It is highly unlikely that oak could have survived in any number after this catastrophic event. Thus, if oak did use the Columbia Gorge as a migrational corridor, it must have done so after 13,000 years b.p. 
Given these two conditions, two possible sequences of Oregon white oak's migration into the study area exist. Hypsithermal warming and drying, which lasted from approximately 4000-8000 years b.p., would have facilitated movement from the Willamette-Puget Trough through the Gorge by alleviating competition with Douglas fir and ponderosa pine. At the close of the Hypsitherm, with annual precipitation increasing east of the Cascades, oak could have moved south between the Cascades and the Deschutes River, thus arriving at its present position. Placing the initial migration into the Gorge at 13,000 years b.p., the application of maximum dispersal rates of $20 \mathrm{~km}$ per 1000 years yields an oak advance of $260 \mathrm{~km}$, which exceeds the present southern extension of oak's range. Thus, this explanation is plausible if $\underline{Q}$. garryana's center of distribution was the Willamette Valley.

An alternative explanation is that oak inhabited central Oregon throughout the Pleistocene, thus serving as a center of post-Pleistocene dispersal into western Oregon and Washington. The strength of this explanation rests in the climatic data referred to earlier, whereby $\mathrm{Q}$. garryana was found to migrate upslope during dry periods and downslope into the sagebursh/juniper zone during moist periods. This area is thus open to plant migration during periods of environmental change and, once inhabiting such an area, Oregon white oak would be difficult to displace. The Willamette-Puget Trough, however, is a closed system for plant migration; it lacks an arid zone refuge which xeric species could inhabit during increasingly moister and cooler periods such as the Pleistocene. If oak did winter-over in the Willamette-Puget Trough in favorable microhabitats, as seems to be the case, it should have been even more capable of weathering conditions east of the Cascades, where conditions 
were more amenable to xeric-type species.

\section{SUMMARY}

Oregon white oak was previously thought to have migrated north from California into its present position during the Hypsithermal maximum. The pollen record and acorn dispersal rates do not, however, substantiate this hypothesis; oak must have inhabited the Pacific Northwest well before the Hypsitherm. Application of acorn dispersal rates to $Q$. kelloggii infer that this species could have colonized its present northern frontier position during the Hypsitherm.

Two explanations are proposed for $Q$. garryana's occurrence in central Oregon: 1) it migrated east through the Columbia Gorge after the Missoula Flood, reaching its farthest southern and eastern extension during the recent moisture maximum; or 2) it was present in central Oregon throughout the Pleistocene, possibly back to Pliocene times. 
CHAPTER $\mathrm{X}$

MAJOR CONCLUSIONS

\section{METHODOLOGICAL CONCLUSIONS}

1. Size-structure evaluation is an effective means of establishing population equilibrium in tree species. If age-structures are found to statistically correlate with size-structures, aberrations from the expected regression curve can be compared to concurrent environmental changes in order to interpret possible cause and effects.

2. Q. garryana does not lend itself to increment core-dating due to progressive heart rot. Some other means of dating needs to be developed for individuals over 100 years of age.

3. Comparison of population dynamics to environmental factors is particularly fruitful if a radical change, such as the 1930 s drought, is available as an index.

4. Acorns can be effectively marked with red spray paint for retrieval the following year. By plotting the position of retrieved acorns, an interpretation of oak's intrinsic dispersal capabilities can be made.

5. Acorns are adapted to dispersal by woodpeckers, jays and squirrels. While gross estimates of the distance carried can be made by simple observation, more accurate tracking of territorial characteristics would increase the reliability of these measurements. Through measurement of the average seed dispersal distances and with a knowledge of the time required from seed germination to tree maturity, estimates of potential rates of population movement can be made. 
6. Ethnographic data can be used to either support or refute claims of human dispersal of seeds.

7. Pollen records can be used to date the colonization of an area by a plant species if a peat depth versus age relationship has been established for the area.

\section{BIOGEOGRAPHIC CONCLUSIONS}

1. Q. garryana is generally replacing itself in central Oregon.

2. There is no reliable evidence that oak is either expanding or retreating in its range. Youthful age-structures at the periphery of its range, which would indicate population expansion, were not found. While several sites exhibited unhealthy size-structures, these can largely be attributed to man's land-use activities.

3. Acorn sprouting is rare as a means of regeneration. This may be an adapted characteristic, since frequent regeneration in a longlived species is not necessary. Thick sod or duff layers may also be inhibiting acorn germination. Coppice sprouting, however, is common in oak in central Oregon. Although this stress reaction would be an effective means of recolonization after fire, it could not aid in oak population diffusion.

4. Oregon white oak is a climax species throughout much of its north-central Oregon range. It exclusively occupies a narrow band between the sagebrush/grassland/juniper and the ponderosa pine/Douglas fir associations.

5. Oak is delimited by the $300 \mathrm{~mm}$ and $1500 \mathrm{~mm}$ isohyets. The microclimatic effects of differing slope aspect may help to account for this great range in moisture tolerance. 
6. The effect of climatic change on oak's population structure varies greatly. It was partially eliminated at its arid periphery during the 1930s drought, but recovered during moist periods, while at its coniferous frontier it yielded to evergreen competition during moist periods, but expanded into this area during the drought. The sum total of Oregon white oak's response to climatic change was retreat at one frontier and expansion at the other.

7. There was a direct correlation between precipitation variation and oak regeneration at sites not overly impacted by human activity.

8. Sites with unhealthy size-structures strongly correlated with the occurrence of heavy livestock grazing. This activity threatens to eliminate $\mathrm{Q}$. garryana from these areas if given a long enough period of time.

9. Acorns quickly germinate in areas relieved of cattle grazing pressure, possibly in response to the elimination of competitive herbs and the tight sod layer.

10. Animals consume acorns and the terminal buds of oaks in natural ecosystems. The direct effects of native herbivory is not known, although a symbiotic relationship whereby $Q$. garryana and the herbivores exchange carbohydrate nutrition for acorn dispersal is indicated. Elimination of the upper trophic level elements, such as raptors and large mammals, may be expected to disrupt this balanced relationship, possibly resulting in increased predation on acorns and thus a drop in seed regeneration.

11. Gravity fall and roll is a slow means of acorn dispersal and, due to competition with the mother tree and heavy predation, not very effective. 
12. The acorns of Oregon white oak are probably not disseminated by running water due to their weight and low-longevity, although flood stage conditions could conceivably negate these limitations.

13. Steller's jays are the most effective means of acorn dispersal, followed by Lewis' woodpeckers and Douglas' squirrels. A maximum acorn dispersal rate of $20 \mathrm{~km}$ per 1000 years for Steller's jays and 4 km per 1000 years for Lewis' woodpeckers was prediceted.

14. The habit of roasting acorns prior to consumption precludes the early Wasco-Wishram Indians from acting as vectors of acorn dissemination in central Oregon. In the Willamette-Puget Trough, however, Indian dispersal of viable acorns may be a factor in oak distribution.

15. Q. garryana was present in the Willamette-Puget Trough during at least the Wisconsin glacial advance.

16. Two possibilities exist for Oregon white oak's presence in central Oregon: 1) it migrated from western Oregon through the Columbia Gorge immediately after the Missoula Flood; or 2) it inhabited central Oregon throughout the Pleistocene, migrating upslope and downslope as climatic conditions dictated. 


\section{REFERENCES CITED}

Allison, I.S. 1935. "Glacial Erratics in the Willamette Valley," Bul1. Geo1. Soc. Ameri. 46:615-32.

Axelrod, D.J. 1976. History of the Coniferous Forests, California and Nevada. Univ. of Calif. Publ. in Botany. Vol. 70.

Bakker, E.S. 1971. An Island Called California. Univ. of Calif. Press, Berkeley.

Baldwin, E.M. 1959. Geology of Oregon. Univ. of Oregon Coop. Bookstore.

Barbour, M.G. 1969. "Age and Space Distribution of the Desert Shrub (Larrea divaricata)," Ecology 50:679-85.

Bretz, J.H. 1925. "The Spokane Flood Beyond the Scablands," Journal of Geol. 33:236-59.

Brogan, P.F. 1964. East of the Cascades. Binfords and Mort.

Chaney, R.W., editor. 1944. "The Dalles Forest," Pliocene Floras of California and Oregon, pp. 285-321.

$56 \mathrm{p}$

- 1948. Ancient Forests of Oregon. Condon Lecture Series,

Cholis, G.J. 1952. "Range Conditions in Eastern Washington 50 Years Ago and Now," Journ. of Range Mgmt. 3(3):129-34.

Cotton, J.S. 1904. "A Report on the Range Conditions of Central Washington," Wash. Agr. Exp. St. Bu11. 60. 45 p.

Coupland, R.T. 1958. "The Effects of Fluctuations in weather Upon the Grasslands of the Great Plains," Botanical Rev. 24(5):274-317.

Crocker, W. and L.V. Barton. 1953. "Physiology of Seeds," In Physiology of Trees, P.J. Kramer, editor.

Cruden, R.W. 1966. "Birds as Agents of Long Distance Dispersal," Evolution 20:517-32.

Deevey, E.S. 1957. "Postglacial Hypsithermal Interval," Science $125: 182-4$.

DenUy1, D. 1945. "Farm Woodlots Should Not Be Grazed," Journal of Forestry $43(10): 729-32$.

Detling, L.E. 1958. "Peculiarities of the Columbia River Gorge Flora," Madrono 14:160-72. 
- 1961. "The Chaparral Formation of Southwestern Oregon, with Considerations of its Postglacial History," Ecology 42:348-57.

- 1966. "The Flora of the Columbia River Gorge," Northwest Science $40(4): 133-7$.

- 1968. "Historical Background of the Flora of the Pacific Northwest," Univ. of Oregon Museum of Natural History, Bul1. 13, 57 p.

E1ton, C.S. 1958. The Ecology of Invasions by Animals and Plants. John Wiley \& Sons.

Flint, R.F. 1971. Glacial and Quaternary Geology. John Wiley \& Sons.

Fremont, J.C. 1887. Memoirs of My Life. Belford, Clark \& Company.

French, D. 1961. "Wasco-Wishram," in Perspectives in American Indian Change, E.H. Spicer, editor. Univ. of Chicago Press.

French, D. 1977. Personal Interview.

Fritts, H.R. 1976. Reconstruction of Past Climatic Variability. Laboratory of Tree Ring Research, Tucson, Arizona.

Fryxel1, R. 1965. "Mazama and Glacier Peak Volcanic Ash Layers: Relative Ages," Science 147:1288-90.

Galbraith, W.A. and E.W. Anderson. 1971. "Grazing History of the Northwest," J. Range Mgmt. $24(1): 6-12$.

Gibson, H. 1913. American Forest Trees. Chicago: Hardwood Record.

Griffin, J.R. 1976. "Regeneration in Q. 1obata Savannas, Santa Lucia Mountains, Calif.," Amer. Midland Naturalist 95:422-35.

- 1977. "Oak Woodland," in Terrestrial Vegetation of California. M.G. Barbour and J. Major, editors, pp. 384-413. John Wiley \& Sons.

Gunther, Erna. 1945. Ethnobotany of Western Washington. Univ. of Wash. Press.

Ha11, F.C. 1956. "Use of Oak Woodlands (Q. garryana) for Farm Forestry and Grazing in the Willamette Valley." (M.S. Thesis, Oregon State University).

Hansen, H.P. 1938. "Postglacial Forest Succession and Climate in the Puget Sound Region," Ecology 19:528-42.

- 1940. "Paleoecology of Two Peat Bogs in Southwest British Columbia," American Journal of Botany $27: 144-9$.

- 1941a. "Paleoecology of a Bog in the Spruce-Hemlock Climax of the 0lympic Peninsula," American Midland Naturalist 25:290-7. 
- 1941b. "Paleoecology of Two Peat Bogs on the Oregon Coast," Oregon State Monograph Studies in Botany 3.

- 1942. "A Pollen Study of the Lake Sediments in the Lower Willamette Valley of Western Oregon," Bulletin, Torrey Botanical Club 69:262-80.

- 1943a. "Paleoecology of Two Sand Dune Bogs on the Southern Oregon Coast," American Journal of Botany 30:335-40.

- 1943b. "A Pollen Study of Two Bogs on Orcas Island, of the San Juan Islands, Washington," Bulletin, Torrey Botanical Club 70:23643.

- 1943c. "Further Pollen Studies of the Peat Bogs on the Pacific Coast of Oregon and Washington," Bulletin, Torrey Botanical Club $71: 627-36$.

- 1947. "Postglacial Forest Succession, Climate and Chronology in the Pacific Northwest," Transactions, American Philosophical Society $37: 1-130$.

- 1950. "Pollen Analysis of Three Bogs on Vancouver Island, Canada," Canadian Journal of Ecology $38: 270-76$.

Hanzlik, E.J. 1928. Trees and Forests of the Western United States. Portland, Oregon: Durham Printing Co.

Hett, J.M. and O.L. Louks. 1971. "Sugar Maple (Acer saccharum Marsh) Seedling Mortality," Journal of Ecology 59:507-520.

Hett, J.M. 1971. "A Dynamic Analysis of Age in Sugar Maple Seedings," Ecology $52(6): 1071-73$.

Heusser, C.J. 1960. "Late Pleistocene Environments of North Pacific North America," American Geographic Society Special Publication, 35.

- 1964. "Palynology of Four Bog Sections from the Western Olympic Peninsula, Washington," Ecology 45(1):23-40.

Hickman, J.C. 1968. "Disjunction and Endemism in the Flora of the Central Western Cascades of Oregon: An Historical and Ecological Approach to Plant Distribution." (Ph.D. Dissertation, University of Oregon.)

Highsmith, R.M. 1968. Atlas of the Pacific Northwest. Oregon State University Press.

Hitchcock, C.L. and A.R. Cronquist. 1973. Flora of the Pacific Northwest. Univ. of Washington Press. Seattle, Wash.

Holland, V.L. 1976. "In Defense of Blue Oaks," Fremontia 3-8. 
Horn, K. 1977. Personal Interview. U.S. Forest Service.

Hulten, E. 1937. Outline of the History of Arctic and Boreal Biota During the Quaternary Period. Stockholm.

Ingles, L.G. 1965. Mammals of the Pacific States: California, Oregon and Washington. Stanford University Press.

Janzen, D.H. 1970. "Herbivores and the Number of Tree Species in Tropical Forests," American Naturalist 104:501-28.

- 1971. "Escape of Juvenile Dioclea Megacarp Vines from Predators in a Deciduous Tropical Forest," American Naturalist 105:97-112.

Johannessen, C.L., Davenport, W.A., Millet, A., and S. McWilliams, "The Vegetation of the Willamette Valley," Annals, Association of American Geographers 61(2):286-302.

Johnson, F.L. and P.G. Risser. 1975. "A Quantitative Comparison between an Oak Forest and an Oak Savanna in Central Oklahoma," Southwestern Naturalist $20(1): 75-84$.

Keen, F.P. 1937. "Climatic Cycles in Eastern Oregon as Indicated by Tree Rings," Monthly Weather Review 65(5):175-88.

Korstian, C.F. 1927. "Factors Controlling Germination and Early Survival in Oaks," Yale University School of Forestry Bulletin 19:1115.

Kozlowski, T.T. 1962. "Climate and Tree Growth," in Tree Growth, T.T. Kozlowski, editor.

Kramer, P.J. 1960. Physiology of Trees. McGraw Hill Co.

Larrison, E.J. 1976. Mammals of the Northwest. Seattle Audubon Society.

Leak, W.B. 1965. "The 'J'-Shaped Probability Distribution," Forest Science 11:405-9.

McKee, B. 1972. Cascadia: The Geologic Origin of the Pacific Northwest. McGraw Hill Co.

Mack, R.N., Bryant, V.M., and R. Fryxe11. 1976. "Pollen Sequence from the Columbia Basin, Washington: Reappraisal of Post-glacial Vegetation," American Midland Naturalist 95(2):390-7.

Mahar, J.M. 1953. "Ethnobotany of the Oregon Paiutes of the Warm Springs Indian Reservation." (B.S. Thesis, Reed College, Portland, Ore.)

McCulloch, W.F., 1940. "Oregon Oak - Tree of Conflict," American Forests $46(6): 264-6$. 
Munger, T.T. 1940. "The Cycle from Douglas Fir to Hemlock," Ecology $21: 415-59$.

Newcomb, R.C. 1969. "Geology of the Deschutes-Umatilla Plateau, United States Geological Survey, Mineral and Water Resources of Oregon." Oregon Department of Mineral Industries.

Page, L. 1937. "Temperature and Rainfall Changes in the United States During the Past 40 Years," Monthly Weather Review 65(2):46-53.

Paine, R.T. 1966. "Food Web Complexity and Species Diversity," American Naturalist 100:65-75.

Peterson, J. 1975. "A Sketch of Kalapuya Ethnography," in Archaeological Studies in the Willamette Valley, C.M. Aikens, editor.

Ridley, H.N. 1930. The Dispersal of Plants Throughout the World. Ashford, Ketn: L. Reeve \& Co.

Rigg, G.B. and H.R. Gould. 1957. "Age of Glacial Peak Eruption, and Glacial Chronology of Post-Glacial Peat Deposits in Washington and Surrounding Areas," American Journal of Science 255:341-63.

Ross, T.D. 1975. "Biosystematics of Quercus garryana in Relation to its Distribution in the State of Washington, "Northwest Science $49(2): 49-57$.

Rumme1, R.S. 1951. "Some Effects of Livestock Grazing on Ponderosa Pine Forest and Range in Central Oregon," Ecology 32(4):594-607.

Smith, A.D. 1957. "Nutritive Value of Some Browse Plants in Winter," J. of Range Mgmt. $10(4): 162-4$.

Spier, L. and E. Sapir. 1930. "Wishram Ethnography," University of Washington Publications in Anthropology 3(3):151-300.

Steinbrenner, E.C. 1951. "Effect of Grazing on Floristic Composition and Soil Properties of Farm Woodlots in Southern Wisconsin," J. of Forestry 49:906-9.

Thilenius, J.F. 1964. "Synecology of the White Oak (Q. garryana) Woodlands of the Willamette Valley, Oregon." (Ph.D. Dissertation, University of Oregon, Eugene, Oregon).

Thwaites, R.G., editor. 1904. Original Journals of the Lewis and Clark Expedition, 1804-6.

Udvardy, N.D.F. 1969. Dynamic Zoogeography. Von Nostrand Reinhald Co.

U.S. Department of Agriculture. 1965. Silvics of Forest Trees of the United States, Agriculture Handbook No. 271, pp. 596-99. 
Verne, L.J. 1953. "Production and Utilization of Acorns in Clinton County, Michigan." (M.S. Thesis, Michigan State University, Ann Arbor, Michigan.)

Visher, S.S. 1954. Climatic Atlas of the United States. Harvard University Press: Cambridge.

Weaver, H. 1950. "Shoals and Reefs in Ponderosa Pine Silviculture," J. of Forestry $48: 121-123$.

Whittaker, R.H. 1975. Communities and Ecosystems. McMillan Publishing Co.

Wolfe, J.A. 1969. "Neogene Floristic and Vegetational History of the Pacific Northwest," Madrono 20:83-109. 
APPENDIX I

PLANTS IDENTIFIED IN THE STUDY AREA

\begin{tabular}{|c|c|}
\hline Oregon White Oak & Quercus garryana Dougl. \\
\hline Douglas Fir & Pseudotsuga menziesii (Mirb.) Franco \\
\hline Ponderosa Pine & Pinus ponderosa Doug1. ex Loud \\
\hline Incense Cedar & Libocedrus decurrens Torr. \\
\hline Hairy Manzanita & Arctostaphylos columbiana Piper \\
\hline Snowbrush & Ceanothus velutinus Doug1. ex Hook \\
\hline Wild Rose & Rose $s s p$ \\
\hline Bitterbrush & Purshia tridentata Pursh (DC) \\
\hline Wild Strawberry & Fragaria vesca (L) \\
\hline Horsetail & Equisetum ssp. \\
\hline Arrowleaf Balsamroot & Balsamorhiza deltoidea Nutt \\
\hline Compositae & $?$ \\
\hline Western Juniper & Juniperus occidentalis Hook \\
\hline Oceanspray & Holodiscus discolor (Pursh) Maxim \\
\hline Oregongrape & Berberis nervosa Pursh \\
\hline Berry & Rubus ssp. \\
\hline Sedge & Carex ssp. \\
\hline Water Birch & Betula occidentalis Hook \\
\hline Columbine & Aquilegia formosa Fisch. \\
\hline Ninebark & Physocarpus capitatus (Pursh) Ktze. \\
\hline Big Sagebrush & Artemisia tridentata Nutt \\
\hline Cheatgrass & Bromus tectorum (L) \\
\hline Lomatium & Lomatium ssp. \\
\hline
\end{tabular}




\begin{tabular}{|c|c|}
\hline Snowberry & Symphoricarpos albus (L) Blake \\
\hline Willow & Salix ssp. \\
\hline Currant & Ribes ssp. \\
\hline Rabbitbrush & Chrysothamnus ssp. \\
\hline Yarrow & Achillea millefolium (L) \\
\hline Grand Fir & Abies grandis (Dougl.) Lindl. \\
\hline Blackberry & Rubus ursinus Cham and Schlecht. \\
\hline Poison Oak & Rhus diversiloba $T$. and $G$. \\
\hline Western Hazel & Corylus cornuta Marsh \\
\hline Idaho Fescue & Festuca idahoensis E1m \\
\hline Big Leaf Maple & Acer macrophyllum Pursh \\
\hline Vine Maple & Acer circinatum Pursh \\
\hline Bluebunch Wheatgrass & Agropyron spicatum (Pursh) Scirbn, and Smith \\
\hline Serviceberry & Amelanchier alnifolia Nutt \\
\hline Lupine & Lupinus ssp. \\
\hline Pearly Everlasting & Anaphalis margaritacea (L) B. and $H$. \\
\hline Western Hawthorn & Crataegus douglasii Lindl. \\
\hline
\end{tabular}


APPENDIX II

BIRDS IDENTIFIED IN THE STUDY AREA

\begin{tabular}{|c|c|}
\hline Steller's Jay & (Cyanocitta stelleri) \\
\hline Lewis' Woodpecker & (Asyndesmus lewis) \\
\hline Mt. Chickadee & (Parus gambeli) \\
\hline Chestnut-backed Chickadee & (Parus rufescens) \\
\hline Western Meadowlark & (Sturnella neglecta) \\
\hline Downy Woodpecker & (Dendrocopos pubescens) \\
\hline Oregon Junco & (Junco oreganus) \\
\hline Varied Thrush & (Ixoreus naevius) \\
\hline Rufous-sided Towhee & (Pipilo erythrophthalmus) \\
\hline Ruby-crowned Kinglet & (Regulus calendula) \\
\hline Red-tailed Hawk & (Buteo jamaicensis) \\
\hline Red-shafted F1icker & (Colaptes cafer) \\
\hline Unidentified Buteo & (Buteo ssp.) \\
\hline Unidentified Sparrow & $(? ?)$ \\
\hline Black-billed Magpie & (Pica pica) \\
\hline Belted Kingfisher & (Megaceryle alcyon) \\
\hline Common Crow & (Corvus brachyrhynchos) \\
\hline Starling & (Sturnus vulgaris) \\
\hline Great Blue Heron & (Ardea herodias) \\
\hline Blue Jay & (Cyanocitta cristata) \\
\hline Golden-crowned Kinglet & (Regulus satrapa) \\
\hline Red-breasted Nuthatch & (Sitta canadensis) \\
\hline California Quail & (Lophortyx californicus) \\
\hline
\end{tabular}


Rock Wren

Anna 's Hummingbird

Fox Sparrow

Cedar Waxwing

Golden Eagle

White-breated Nuthatch

White-headed Woodpecker

Turkey Vulture
(Salpinctes obsoletus)

(Calypte anna)

(Passerella iliaca)

(Bombycilla garrula)

(Aquila chrusaetos)

(Sitta carolinensis)

(Dendrocopos albolarvatus)

(Cathartes aura) 


\section{APPENDIX III}

TABLE I

CALCULATION OF ANNUÁL RING DATA

\begin{tabular}{rrrrr}
\multicolumn{1}{c}{$\mathbf{x}$} & $\mathbf{y}$ & $\mathrm{x}^{2}$ & \multicolumn{1}{c}{$\mathbf{y}^{2}$} & $\mathbf{x y}$ \\
\hline 28 & 10 & 784 & 100 & 280 \\
32 & 14 & 1084 & 196 & 448 \\
33 & 8 & 1089 & 64 & 264 \\
35 & 11 & 1225 & 132 & 385 \\
36 & 23 & 1296 & 529 & 828 \\
38 & 12 & 1444 & 144 & 456 \\
43 & 12 & 1849 & 144 & 516 \\
48 & 23 & 2304 & 529 & 1104 \\
49 & 38 & 2401 & 1444 & 1862 \\
52 & 25 & 2704 & 625 & 1300 \\
53 & 20 & 2809 & 400 & 1060 \\
55 & 20 & 3025 & 400 & 1100 \\
55 & 26 & 3136 & 676 & 1456 \\
63 & 33 & 3969 & 1089 & 2079 \\
84 & 51 & 7056 & 2601 & 4284 \\
$\varepsilon 705$ & $\varepsilon 326$ & $\varepsilon 36,175$ & $\varepsilon 9073$ & $\varepsilon 17,422$ \\
\hline
\end{tabular}

$\overline{\mathrm{x}}=47.0 \quad \overline{\mathrm{y}}=21.7$

Coefficient of Correlation

$r=\frac{n(\varepsilon x y)-(\varepsilon x)(\varepsilon y)}{\sqrt{n\left(\varepsilon x^{2}\right)-(\varepsilon x)^{2}} \cdot \sqrt{n\left(\varepsilon y^{2}\right)-(\varepsilon y)^{2}}}$

$r=\frac{31,500}{\overline{63615} \cdot \overline{29819}}=.723$

- $\mathrm{n}(15)=.514<.723$

- there is linear correlation

Estimation of Sum of Squares (ss)

$s s=\frac{\left.\left(\varepsilon y^{2}\right)-b_{o}(\varepsilon y)\right)-\left(b_{1}(\varepsilon x y)\right)}{n-2}$ 
Estimation of Sum of Squares (continued)

$$
\begin{aligned}
& s s=\frac{9073+3488.2-12021.2}{13} \\
& s s=41.5 \\
& \therefore s s_{b_{1}}=\frac{n(s s)}{n\left(\varepsilon x^{-}\right)-(\varepsilon x)^{2}}=0.013
\end{aligned}
$$

\section{Linear Function}

$$
\begin{aligned}
b_{1} & =\frac{n\left(\varepsilon_{x y}\right)-(\varepsilon x)(\varepsilon y)}{n\left(\varepsilon x^{2}\right)-(\varepsilon x)^{2}} \\
b_{1} & =\frac{31500}{45600}=.69 \\
b_{0} & =y-b_{1} x \\
& =21.7-.69(47) \\
b_{0} & =-10.7 \\
\hat{y} & =-10.7+.69 x
\end{aligned}
$$

\section{Estimation of $x$ from $y$ (inverse prediction)}

$\hat{x}=\frac{(y-a)}{b y^{--} \cdot x} \quad$ This gives the $\hat{x}$ value

For $95 \%$ confidence limits:

$D=b^{2} y \cdot x-t^{2} .05(n-2) s^{2} b$

$D=(.69)^{2}-(2.16)^{2}(.013)$

$D=.47-.06=.41$

Then $H=\frac{t .05(n-2)}{D} \sqrt{S^{2} y \cdot x\left[D(1+1 / 2)+\frac{(y i-\vec{y})^{2}}{\varepsilon x^{2}}\right]}$

Then, with $\mathrm{H}$ for a particular $\mathrm{y}$ in question, the $95 \%$ confidence limits are set by: 


$$
\begin{aligned}
& L_{1}=\bar{x}+\frac{b y \cdot x(y i-\bar{y})}{D}-H \\
& L_{2}=\bar{x}+\frac{b y \cdot x(y i-\bar{y})}{D}+H
\end{aligned}
$$

To convert a particular $\mathrm{DBH}$ in centimeters to circumference in inches, $\frac{\mathrm{DBH} \cdot \pi}{2.4}=$ circumference in inches.

\section{TABLE II}

INVERSE PREDICTIONS OF X (AGE) FROM Y (DBH)

\begin{tabular}{rccccc}
$\mathrm{dbh}(\mathrm{cm})$ & $\begin{array}{c}\text { (y) inches } \\
\text { in circ. }\end{array}$ & $\mathrm{H}$ & $\begin{array}{c}\mathrm{X} \text { (age } \\
\text { in years) }\end{array}$ & $\begin{array}{c}\mathrm{L}_{1}(95 \% \\
\text { conf. } \\
\text { limits }\end{array}$ & $\begin{array}{l}\mathrm{L}_{2} 95 \% \\
\text { conf. } \\
\text { limits }\end{array}$ \\
\hline 5 & 6.6 & 22.3 & 25.0 & -1.0 & 43.8 \\
6 & 7.8 & 22.3 & 26.8 & 1.3 & 45.9 \\
7 & 9.2 & 22.3 & 28.8 & 3.7 & 48.3 \\
8 & 10.5 & 22.3 & 30.7 & 5.8 & 50.4 \\
9 & 11.8 & 22.2 & 32.6 & 8.1 & 52.5 \\
10 & 13.0 & 22.2 & 34.3 & 10.1 & 54.6 \\
11 & 14.4 & 22.2 & 36.4 & 12.5 & 56.9 \\
12 & 15.7 & 22.2 & 38.3 & 14.7 & 59.1 \\
13 & 17.0 & 22.2 & 40.1 & 16.9 & 61.3 \\
14 & 18.3 & 22.2 & 42.0 & 19.1 & 63.5 \\
15 & 19.6 & 22.2 & 43.9 & 21.3 & 65.6 \\
16 & 20.9 & 22.2 & 45.8 & 23.4 & 67.8 \\
17 & 22.2 & 22.2 & 47.7 & 25.6 & 70.0 \\
18 & 23.6 & 22.2 & 49.7 & 28.0 & 72.4 \\
19 & 24.9 & 22.2 & 51.6 & 30.2 & 74.6 \\
20 & 26.2 & 22.2 & 53.5 & 32.4 & 76.7 \\
21 & 27.5 & 22.2 & 55.4 & 34.6 & 79.0 \\
22 & 28.8 & 22.2 & 57.2 & 36.7 & 81.1 \\
23 & 30.1 & 22.2 & 59.1 & 38.9 & 83.3 \\
24 & 31.4 & 22.2 & 61.0 & 41.1 & 85.5 \\
25 & 32.7 & 22.3 & 62.9 & 43.2 & 87.8 \\
26 & 34.0 & 22.3 & 64.8 & 45.4 & 90.0 \\
27 & 35.3 & 22.3 & 66.7 & 47.6 & 92.2 \\
28 & 36.6 & 22.3 & 68.5 & 49.8 & 94.4 \\
29 & 38.0 & 22.3 & 70.6 & 52.1 & 96.7 \\
30 & 39.2 & 22.4 & 72.3 & 54.3 & 98.6 \\
31 & 40.6 & 22.4 & 74.3 & 56.4 & 101.2 \\
32 & 41.9 & 22.5 & 76.2 & 58.5 & 103.5 \\
33 & 43.2 & 22.5 & 78.1 & 60.7 & 105.7 \\
34 & 44.5 & 22.5 & 80.0 & 62.9 & 107.9 \\
35 & 45.8 & 22.5 & 81.9 & 65.0 & 110.0 \\
\hline & & & & & \\
\hline
\end{tabular}


TABLE II (continued)

$\mathrm{dbh}(\mathrm{cm}) \quad(\mathrm{y})$ inches $\mathrm{H}$ in circ.
$X$ (age
in years) $\begin{array}{ll}\mathrm{L}_{1}(95 \% & \mathrm{L}_{2}(95 \%) \\ \text { conf. } & \text { conf. }\end{array}$ limits limits

61

62

63

64

65

66

67

68

69

70

71

72

73

74

75

76

77

78

79

80
47.1

48.4

49.7

51.0

52.3

53.7

55.0

56.3

57.6

58.9

60.2

61.5

62.8

64.1

65.4

66.7

68.1

69.4

70.7

72.0

73.3

74.6

75.9

77.2

78.5

79.8

81.1

82.5

83.8

85.1

86.4

87.7

89.0

90.3

91.6

92.9

94.2

95.5

96.9

98.2

99.5

100.8

102.1

103.4

104.7
22.6

22.7

22.7

22.8

22.8

22.9

22.9

22.9

22.9

23.0

23.1

23.2

23.2

23.3

23.4

23.5

23.5

23.6

23.7

23.8

23.9

24.0

24.1

24.2

24.5

24.4

24.5

24.6

24.7

24.8

24.9

25.0

25.1

25.2

25.3

25.5

25.6

25.7

25.8

25.9

26.0

26.2

26.3

26.4

26.5
83.8

85.6

87.5

89.4

91.3

93.3

95.2

97.1

99.0

100.8

102.7

104.6

106.5

108.4

110.3

112.2

114.2

116.1

118.0

119.9

121.7

123.6

125.5

127.4

129.3

131.1

133.0

135.1

136.9

138.8

140.7

142.6

144.5

146.4

148.3

150.1

152.0

153.9

155.9

157.8

159.7

161.6

163.5

165.4

167.2
67.1

69.2

71.4

73.5

75.7

77.9

80.1

82.3

84.4

86.5

88.6

90.8

92.9

94.9

97.0

99.2

101.5

103.6

105.7

107.7

109.9

112.0

114.1

116.2

118.3

120.4

122.5

124.7

126.8

128.9

131.0

133.1

135.1

137.2

139.3

141.3

143.4

145.5

147.8

149.8

151.9

153.9

156.0

158.1

160.2
110.0

112.3

114.6

116.8

119.1

121.3

123.7

125.9

128.1

130.4

132.7

135.0

137.2

139.5

141.7

144.0

146.2

148.7

151.0

153.3

155.5

157.7

160.0

162.3

164.6

166.9

169.2

171.5

173.9

176.2

178.5

180.8

183.1

185.4

187.6

189.9

192.3

194.6

196.9

199.3

201.6

203.9

208.6

210.9 